Illinois State University

ISU ReD: Research and eData

Theses and Dissertations

3-8-2017

\title{
The Byline of Europe: An Examination of Foreign Correspondents' Reporting from 1930 to 1941
}

Kerry J. Garvey

Illinois State University, kjgarve@gmail.com

Follow this and additional works at: https://ir.library.illinoisstate.edu/etd

Part of the European History Commons, Journalism Studies Commons, and the Mass Communication Commons

\section{Recommended Citation}

Garvey, Kerry J., "The Byline of Europe: An Examination of Foreign Correspondents' Reporting from 1930 to 1941" (2017). Theses and Dissertations. 671.

https://ir.library.illinoisstate.edu/etd/671

This Thesis is brought to you for free and open access by ISU ReD: Research and eData. It has been accepted for inclusion in Theses and Dissertations by an authorized administrator of ISU ReD: Research and eData. For more information, please contact ISUReD@ilstu.edu. 


\title{
THE BYLINE OF EUROPE: AN EXAMINATION OF FOREIGN CORRESPONDENTS' REPORTING FROM 1930 TO 1941
}

\author{
Kerry J. Garvey
}

\section{Pages}

This thesis focuses on two of the largest foreign correspondents' networks the one of the Chicago Tribune and New York Times- in prewar Europe and especially in Germany, thus providing a wider perspective on the foreign correspondents' role in news reporting and, more importantly, how their reporting appeared in the published newspaper. It provides a new, broader perspective on how foreign news reporting portrayed European events to the American public. It describes the correspondents' role in publishing articles over three time periods- 1930 to 1933, 1933-1939, and 1939 to 1941. Reporting and consequently the published paper depended on the correspondents' ingenuity in the relationship with the foreign government(s); their cultural knowledge; and their gender. All of this depended on the correspondents' gender, cultural knowledge, and ingenuity. The reporters who combined them all under the right condition became legends in mass media and set a standard for international reporting. This standard influenced how mass media portrayed foreign conflicts and American's perceptions of them years after the war.

KEYWORDS: Foreign Correspondents, Chicago Tribune, New York Times, Germany, 1930s1940s 
THE BYLINE OF EUROPE: AN EXAMINATION OF FOREIGN CORRESPONDENTS'

REPORTING FROM 1930 TO 1941

KERRY J. GARVEY

A Thesis Submitted in Partial Fulfillment of the Requirements for the Degree of

MASTER OF SCIENCE

Department of History

ILLINOIS STATE UNIVERSITY

2017 
(C) 2017 Kerry J. Garvey 
THE BYLINE OF EUROPE: AN EXAMINATION OF FOREIGN CORRESPONDENTS'

REPORTING FROM 1930 TO 1941

KERRY J. GARVEY

COMMITTEE MEMBERS:

Katrin Paehler, Chair

Qilang He

Ross Kennedy 


\section{ACKNOWLEDGMENTS}

I wish to thank the committee for their help and suggestions throughout this long project. Dr. Kennedy and Dr. He gave me invaluable comments on how to fine tune my argument. I also wanted to say thank you to the History Department for financially supporting my archival research in New York and Wisconsin. The documents I found in both of the archives helped to develop my argument beyond the newspaper articles. They also filled in a lot of the missing pieces. I especially want to thank Dr. Paehler for agreeing to be my thesis advisor. The help and advice she has given me over the years have made a large impact on me as a student and a person. I can say with confidence that I would not be half the history student I am today if I did not walk into her HIS 200 class five years ago. I also wanted to say thank you to Kami for not ignoring my many text messages about grammar rules and content issues. The final two people I would like to thank are my mom and grandma. My mom provided me with support throughout my undergraduate and graduate years. My grandma always offered me words of encouragement when I was ready to throw in the towel. I deeply appreciate the help people have given me over the years. I would not have been able to finish as strongly without the support of my family and ISU's History Department.

K. J. G. 


\section{CONTENTS}

Page

ACKNOWLEDGMENTS

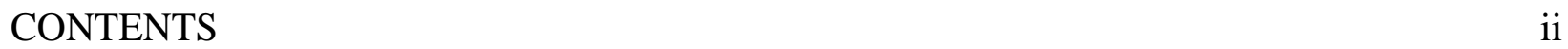

CHAPTER

I. INTRODUCTION: "THE RECORDING ANGELS OF THE 1930S" 1

II. THE JOURNALISTIC EVALUATION OF HILTER'S INTENT

FROM 1930 TO 1934

III. THE NAZIS’ TIGHTENING CONTROL OVER JOURNALISTS’

TYPEWRITERS FROM 1934 TO 1939

IV. THE WAR CORRESPONDENTS FROM 1939 TO 1941

V. CONCLUSION: THE UNSEEN GATEKEEPER OF INFORMATION 


\section{CHAPTER I}

\section{INTRODUCTION: "THE RECORDING ANGELS OF THE 1930S"1}

The camera pans across a large group of foreign correspondents waiting for their chance to get a small moment of time with any one of the foreign leaders springing from their cars and rushing into another peace meeting. The year is August 1939 and Europe is on the brink of yet another war. The correspondents attempt to pump the leaders for any scrap of information about a possible war for their worried readers. One reporter stands apart from the rest of the group, because he physically stopped the head foreign diplomat to get the full story on the progress of the peace conference. In a split second, the correspondent's conversation is cut short by a man in the crowd who shoots the diplomat in the head.

The correspondent acts quickly and begins to chase the man, while all others stare in awe at the dying diplomat. The assassin almost gets away by swiftly hopping into a get-away car, however, the quick-minded foreign correspondent commandeers a friend's car to continue the chase. Swish! Swish! Bullets are flying inches away from his head during the high speed chase with the criminal. In a blink of the eye, the criminal disappears into the countryside without a trace. On a slight hunch, the correspondent stumbles around in an old farm house looking for any sign of the criminal. He discovers the criminal discussing his conspiracy plan to influence the international peace meeting by faking the death of the foreign leader and torturing him for information. The correspondent attempts to bring the criminals to justice, however, he finds that the criminal enterprise infiltrates deep into the government. He must find someone to trust with

\footnotetext{
${ }^{1}$ The phrase, "Recording Angels," comes from the opening credits of Alfred Hitchcock's second film, Foreign Correspondent. See Foreign Correspondent, directed by Alfred Hitchcock, released August 16, 1940 (Hulu, July 3, 2011), video streaming.
} 
his exclusive information, while under the constant threat of the criminal's assassins trying to silence him forever. ${ }^{2}$

This was the overarching plot of Alfred Hitchcock's movie, Foreign Correspondent (1940). ${ }^{3}$ It shows a popularized cultural image of a foreign correspondent from the 1930 s and highlights a romanticized view of their role in foreign news reporting. Hitchcock contextualized his foreign correspondent within this dangerous adventure to uncover the truth for the American public, while other reporters stumbled around in the dark to find news. In the movie, most of the bad reporters sent back foreign governments' official press releases and lived in Europe on their newspapers' dollar. This movie was intended to thrill the audience; nevertheless, it brings up the question what type of correspondent worked in Europe during the 1930s. Was it the correspondent who went for the real story despite the danger? What traits defined a good correspondent? Could Europe have been covered by reporters simply sending governments' official news back home? Most importantly, how did the correspondents' reporting appear in the newspapers for the American public?

This thesis asks these questions with the aim of gaining a better understanding of the American foreign correspondents' role in reporting on political events in Europe to the American public from 1930 to 1941 . This is a case study that focuses on how correspondents were able to report from Germany. Some of the other European nations are also highlighted to help provide a complete picture of how the correspondents' situation changed in relation to Europe's political situation. The purpose is to shed some light on the correspondents' reporting practices and how they influenced the production of news, which is a lacuna in the historiography on journalism.

\footnotetext{
${ }^{2}$ Foreign Correspondent, directed by Alfred Hitchcock, released August 16, 1940.

${ }^{3}$ John Rossi argues that Hitchcock intended to use the foreign correspondents as a vehicle to show how naïve the American public was about the political situation in Europe. For more information on Foreign Correspondent, see John Rossi, "Hitchcock’s Foreign Correspondent," Film \& History 12, no. 2 (May 1982).
} 
Most historians have been more focused on providing broad overviews of how American journalism developed over specific periods of time. These overviews or historical narratives provide a brief discussion about how the news workers and newspapers contributed to the development of journalism. This holds true even for historical monographs about single newspapers or journalists. ${ }^{4}$ Their analyses lack an in-depth examination of any news worker's role in publishing. For example, John Maxwell Hamilton's Journalism's Roving Eye: A History of American Foreign Reporting details how the institution of foreign news reporting developed from the start. He used foreign correspondents as examples of how news organizations' reporting changed, but has little discussion of their role in publishing the news. ${ }^{5}$ This creates a situation in which newspapers become one entity instead of comprised of multiple workers. Generally, historians lack this bottom up approach, because of how news workers have historically been studied.

Kevin Williams argues that the historical focus has been on how the press struggles for political freedom, which virtually ignores their writing practices and limits any discussion on journalism's impact on history. ${ }^{6}$ Therefore, a large gap developed in the historiography on how journalistic practices influenced events. Lea Hellmueller and Claudia Mellado argue that scholars "tend not to study journalistic professional roles from its impact on news content but focus on

\footnotetext{
${ }^{4}$ For examples of historians' narratives about development of journalism see, David Paul Nord, Communities of Journalism: A History of American Newspapers and their Readers (Urbana and Chicago: University of Illinois Press, 2001); Leonard Ray Teel, The Public Press, 1900-1945: The History of American Journalism (Westport, Conn: Praeger Publishers, 2006); and Heidi Tworek, "The Creation of European News: News Agency Cooperation in Interwar Europe," Journalism Studies 14, no. 5 (2013): 730-742. For examples on how historians examined one newspaper and its history see Meyer Berger, The Story of the New York Times 1851-1951 (New York: Simon and Shuster, 1951) and Lloyd Wendt, Chicago Tribune: The Rise of a Great American Newspaper (Chicago: Rand McNally, 1979).

${ }^{5}$ See John Maxwell Hamilton, Journalism's Roving Eye: A History of American Foreign Reporting (Baton Rouge: Louisiana State University Press, 2009).

${ }^{6}$ Kevin Williams, "War Correspondents as Sources for History: Problems and possibilities in Journalism Historiography," Media History 18, no. 3-4 (2012), 341-342.
} 
journalists' conception of their role." ${ }^{77}$ This is despite the fact that foreign news reporters are seen as gatekeeper of transnational information. Hellmueller theorized that their gatekeeper role puts these foreign reporters in a position of power to shape the local newspaper's output. ${ }^{8}$ This thesis intends to add to the historiography by breaking with the myth that newspapers were primarily shaped by their owner. I adapt a bottom up approach throughout this case study, which separates my work from other historians' examinations. Essentially, I am expanding the history on journalism by indicating the agency of journalists and the complexities involved in the making and shaping of the news--back then and today.

A highly complicated system of foreign news reporting emerged in the 1930s through this thesis's case study of Chicago Tribune's and New York Times's foreign correspondents. This system signals the development of a new epoch of international news reporting based on how these correspondents operated within it. This was developed throughout the period, because the correspondents had new governmental challenges for their reporting. The correspondents' ability to face each of them shaped what information about Europe was provided to the American public at a time when the United States' neutrality hung in the balance.

Throughout the 1930s, these correspondents found themselves in an increasingly politically intense situation that affected their ability to report. The interwar period for most of Europe was defined by the aftermath of World War I and the Great Depression. The individual countries had to develop recovery plans for their respective economies, while also maintaining the fragile collective peace from World War I. This peace could not be maintained, because the European nations' foreign policies towards one another. Richard Overy argues that most

\footnotetext{
${ }^{7}$ Lea Hellmueller and Claudia Mellado, "Professional Roles and News Construction: A Media Sociology Conceptualization of Journalists' role Conception and Performance," Communication \& Society 28, no. 3 (2015): 1. ${ }^{8}$ Lea Hellmueller, "Gatekeeping Beyond Geographical Borders: Developing an Analytical Model of Transnational," The International Communication Gazette 79, no. 1 (2017): 3-8.
} 
historians contribute the breakdown to the British and French appeasement policy towards Hitler's demand. This lead to several cracks in the peace that eventually lead to the start of another war in 1939 that engulfed most of the world's nations.9

For the United States, the 1930s and early 1940s were defined by the question of whether or not to become involved with Europe's affairs. The two sides of this debate were defined by the American isolationists and interventionists. ${ }^{10}$ Franklin D. Roosevelt's foreign policy was heavily influenced by the American public's perception of the debate, because he was only able to be as liberal as the willingness of the American public to be involved with Europe. This debate and FDR's foreign policy changed over the course of the period, because events, such as Great Britain possible defeat by Nazi Germany, changed some of the American public's point of view. ${ }^{11}$ More importantly, the information about Europe available to the American public would have influenced their attitudes towards either side of the debate and FDR's foreign policy.

By the 1930s, American journalism was firmly interested in international news coverage. Many newspaper owners saw it has a new market, which had the potential to liven up the news and, more importantly, be profitable. There was no shortage of journalists wanting to go abroad and live an exciting life in Europe. The ones in 1930s were unique from the previous waves, because many of them were college educated. By the 1920s, some schools started to provide

\footnotetext{
${ }^{9}$ Richard Overy, Origins of the Second World War, $3^{\text {rd }}$ ed., Seminar Studies in History, (Harlow, England and London: Pearson Longman, 2008), 4-10.

${ }^{10}$ For more information on how FDR interacted with isolationists and interventionists see Wayne Cole, Roosevelt \& the Isolationists 1932-1945 (Lincoln and London: University, 1988) and Wayne Cole, America First: The Battle Against Intervention 1940-1941 (Madison: The University of Wisconsin Press, 1953). For more information on how interventionists operated in the United States see Andrew Johnstone, Against Immediate Evil: American Internationalists and the Four Freedoms on the Eve of World War II (Ithaca and London: Cornell University Press, 2014).

${ }^{11}$ Richard Breitman and Allan J. Lichtman, FDR and the Jews (Cambridge, Massachusetts and London, England: The Belknap Press of Harvard University Press, 2013), 3-5. Breitman and Lichtman focus their discussion on how FDR changed his foreign policy on his actions towards the Jewish situation in Germany. Justus D. Doenecke's and John E. Wilz's is one of the latest books that discusses the implications of key events in Europe and Asia from 1931 to 1941 on the United States entry into the war see From Isolation to War 1931-1941, $4^{\text {th }}$ ed., The American History Series (Arlington, Ill: Wiley Blackwell, 2015).
} 
courses in journalism to accommodate the growing field. The most notable schools were University of Missouri and Columbia University. ${ }^{12}$ It is important to note that many of the foreign correspondents highlighted in this case study did not receive an education in journalism. Many of these correspondents were already reporting before these programs were largely instituted at the university level, but most of them were college educated.

All across Europe, these correspondents observed crucial political events that led to World War II and reported back to their American newspapers. A handful of them reported on the events in Germany that were central to the start of the war. The correspondents were at least partially responsible for the information published about Germany in major newspapers to the American public and created one of the few windows into these events. The rest of the duty laid with the newspaper owners and their editors who placed and shaped correspondents' reporting within the papers.

Foreign reporting has been a long tradition in newspapers dating back to the early 1900s; however, few of them could afford networks large enough to cover all of Europe. It was not until the 1920s and 1930s that several major newspapers developed extensive foreign correspondent networks. ${ }^{13}$ Some of well-known news services were Chicago Daily News, New York Herald Tribune, New York World, and the Philadelphia Public Ledger- New York Evening Post. The freelance services were the Associated Press, United Press, and Hearst's International News Service. Two of the largest syndicated news services that emerged by the 1930s were the Chicago Tribune and New York Times, which had foreign correspondent networks covering most

\footnotetext{
${ }^{12}$ Morrell Heald, Transatlantic Vistas: American Journalists in Europe 1900-1940 (Kent, Ohio: The Kent State University Press, 1988), 4-16.

${ }^{13}$ Heald, Transatlantic Vistas, 2-5. For information on how American newspapers in general developed during this time period see Leonard Ray Teel, The Public Press, 1900-1945, The History of American Journalism (Westport, Connecticut: Praeger, 2006).
} 
of Europe. ${ }^{14}$ Some of their correspondents' citizenship were not American; however, I classified them as American journalists based on the audience of their reporting. This thesis seeks to understand American foreign news reporting by exploring how foreign correspondents from the Chicago Tribune and New York Times reported on European political events from 1930 to 1941; it is a collective biography of sorts.

I focus on the Chicago Tribune and New York Times, because of their owners' unique perspectives on the political events in Europe, their network of foreign correspondents across Europe, and their similar daily circulation of at least 500,000. ${ }^{15}$ The Chicago Tribune was owned by the charismatic Robert McCormick. He was a well-known isolationist, who voiced his disdain for Franklin D. Roosevelt's domestic and foreign policies through his newspaper. ${ }^{16}$ The New York Times was owned by Arthur Hays Sulzberger, who came from a German Jewish family. He was not highly politicized as either an isolationist or interventionist like McCormick, but he did recognize the plight of Jews. It is important to note that Sulzberger made an effort for The Times not to be labeled as a Jewish newspaper, but to be recognized for its reporting alone. ${ }^{17}$ Therefore, these owners had different opinions on how the United States should address the events unfolding in Europe.

In the 1920s and 1930s, the media owners shaped their newspaper's reporting by placing pressure on the editors and reporters through the threat of unemployment. This threat was

\footnotetext{
${ }^{14}$ For more information on the history of American foreign news reporting see Hamilton, Journalism's Roving Eye, $192-217$.

${ }^{15}$ By the end of the 1930s, the Chicago Tribune's daily circulation passed 900,000. For more information, see Wendt, Chicago Tribune, 599-600. The New York Times had about 500,000 for its daily circulation in the 1930s. For a breakdown see Berger, The Story of The York Times 1851-1951, 569-570.

${ }^{16}$ Jerome E. Edwards, The Foreign Policy of Col. McCormick's Tribune 1929-1941 (Reno, Nevada: University of Nevada Press, 1971), 1-3. For a biography on Colonel Robert McCormick see Richard Norton Smith, The Colonel: The Life and Legend of Robert R. McCormick 1880-1955 (Boston and New York: Houghton Mifflin Company, 1997).

${ }^{17}$ Laurel Leff, Buried by the Times: The Holocaust and America's Most Important Newspapers (Cambridge, Cambridge University Press, 2005), 13-14. A biography does not exist about Arthur Hays Sulzberger. For a history of the New York Times prior and during his tenure as publisher see Meyer Berger, The Story of the New York Times 1851-1951 (New York: Simon and Shuster, 1951).
} 
generally effective, especially in the 1930s with the Great Depression, because the journalists were viewed as "replaceable cogs" in the news reporting system. This mentality developed in the technological advancement age of the $19^{\text {th }}$ century, because reporting became highly efficient which separated the newsroom workers into two divisions, reporters and editors. ${ }^{18}$ This allowed the owners to easily change or write off stories based on their agenda. Furthermore, the reporters were not paid a livable wage which forced many of them to get second jobs or completely leave the profession. The remaining reporters developed a sense of comradery, because they viewed their job as important source of information for the general public's knowledge. This drove some of the reporters in the 1930 s to fight against their owners' wishes. ${ }^{19}$

The New York Times and Chicago Tribune owners had somewhat of a challenge to achieve the correspondents' acquiescence on the account of their distinctive and sometime larger than life personalities. These newspapers were home to some of the most famous foreign correspondents across all of Europe. For example, the Chicago Tribune had Sigrid Schultz reporting from Germany from 1919 to 1941, who earned the nickname "dragon lady from Chicago" from the Nazis, because of her ruthless, observant reporting in Berlin and her strong anti-Nazism. ${ }^{20}$ The New York Times also had several correspondents in Germany. One of their reporters, Otto Tolischus, wrote a stream of negative articles about Germany, and while his articles ended up in the back of the Times, they also led to his expulsion from Germany by the Nazis. ${ }^{21}$ These reporters are only a fraction of the many who will be discussed throughout this

\footnotetext{
${ }^{18}$ Bonnie Brennen, "Cultural Discourse of Journalists: The Material Conditions of Newsroom Labor," in Newsworkers: Towards a History of the Rank and File, ed. Hanno Hardt and Bonnie Brennen (Minneapolis and London: University of Minnesota Press, 1995), 97-99.

${ }^{19}$ Brennen, "Cultural Discourse of Journalists," 101-104.

${ }^{20}$ Frederick S. Voss, Reporting the War: The Journalistic Coverage of World War II (Washington, D.C.: Smithsonian Institution Press for National Portrait Gallery, 1994), 3-5, 8.

${ }^{21}$ Leff, Buried in the Times, 55-56, 61-62.
} 
paper. Generally, I focus on the correspondents who reported on Germany, because of its centrality to events in Europe during the 1930s and they provide a base of analysis for this thesis.

A limited number of historical studies exists on how the printed media and foreign reporters portrayed events in Europe during the 1930s and 1940s. The norm among them has been to write short biographies of famous foreign correspondents or on how individual newspapers and/or journalists reported on events predominantly in Germany. ${ }^{22}$ This thesis differs from these historians by contextualizing foreign correspondents' reporting and actions in their respective situations. Morrell Heald's Transatlantic Vistas American Journalists in Europe is one of the few books that focuses solely on how foreign correspondents in Europe reported on news. He examines how the well-known correspondents from the Chicago Daily News and some famous freelancers were able to report from Europe between 1900 to 1940. Heald suggests that the correspondents took on a new European perspective in their reporting because of their tenure in Europe. Therefore, their reporting provided an angle on Europe that domestic journalists could not take. ${ }^{23}$ Heald's conclusion is not wrong for these select correspondents. Nevertheless, there were multitude of news organizations with plenty of foreign correspondents in Europe during the 1930s and not all of them had the same experiences in Europe.

Case studies of other newspapers and correspondents would shed more light on the foreign correspondents' role in news reporting; however, not many exist especially for the 1930s. ${ }^{24}$ Theodore Edward Kruglak's The Foreign Correspondents: A Study of the Men and

\footnotetext{
${ }^{22}$ For an example of how historians wrote foreign correspondents' biographies see Voss, Reporting the War. For an example of historians focusing on events in Germany see Leff, Buried by the Times and Deborah E. Lipstadt, Beyond Belief: The American Press and the Coming of the Holocaust 1933-1945 (New York \& Toronto: The Free Press, 1986) For an example of how historians studied individual correspondents' reporting in Europe from 1900 to 1940, see Heald, Transatlantic Vistas.

${ }^{23}$ Heald, Transatlantic Vistas, 224-225, 231-234.

${ }^{24}$ For examples of case studies about news reporting in 1930s and World War II see Jacob Kreutzfeldt, "Unidentified Sounds: Radio Reporting From Copenhagen 1931-1949," Journal of Radio \& Audio Media 22, no. 1 (2015): 3-19; Heidi J.S. Tworek, "Journalistic Statesmanship: Protecting the Press in Weimar Germany and
} 
Women Reporting for the American Information Media in Western Europe (1974) is one of the

first monographs that studies foreign correspondents reporting. However, much of his conclusion is based on statistical analyses of their articles in the newspaper, thus, ignoring the correspondents' situation. ${ }^{25}$ This lack of analysis does not change in the historiography, because historians are more focused on news agencies instead of their workers. Case in point, Heidi Tworek's article, "The Creation of European News: News Agency Cooperation in Interwar Europe," (2013) describes how news agencies changed their "mechanisms" to foster international news exchange after World War I. She is focusing on the large global structures of news reporting instead of how reporters operated within them. ${ }^{26}$

There are also a few case studies on how newspapers reported on specific events from Germany in the 1930s; yet, they do not focus solely on foreign correspondents. Laurel Leff's Buried by the Times: The Holocaust and America's Most Important Newspaper (2005) is one of the most extensive case studies on the New York Times. This monograph provides a detailed study on how the New York Times portrayed Nazi Germany and the Holocaust. She argues that the US government was not entirely at fault for the misinformation given to the American public and that the New York Times had some autonomy on how it reported the news. She also suggests that, since the owner and publisher of the Times, Arthur Hays Sulzberger, came from a German Jewish family; he avoided highlighting the German Jewish plight. This would keep his paper from being written off as only a Jewish newspaper. ${ }^{27}$ Ultimately, Leff's monograph and similar

Abroad," German History 32, no. 4 (2014): 559-578; Brianna Buljung, "From the Foxhole: American Newsmen and the Reporting of World War II," International Social Science Review 86, no. 1-1 (2011): 44-64.

${ }^{25}$ Theodore Edward Kruglak, The Foreign Correspondents: A Study of the Men and Women Reporting for the American Information Media in Western Europe (Westport, Connecticut: Greenwood Press, 1974).

${ }^{26}$ Heidi Tworek, "The Creation of European News: News Agency Cooperation in Interwar Europe," Journalism Studies 14, no. 5 (2013): 730-742.

${ }^{27}$ Leff, Buried in the Times, 8-14. Gary Klein's article "When the News Doesn't Fit: The New York Times and Hitler's First Two Months in Office, February/ March 1933" is another example of a how a historian uses the Times as a case study for reporting in Nazi Germany. Klein argues that the Times did not have efficient enough bureau to report 
ones are only focusing on how one newspaper and its owner influenced reporting on one aspect of the war. This creates a rather limited window into newspapers' and correspondents' writing. My thesis' boarder timeline and more general focus on reporting from Germany, thus adds an important facet to this historiography.

Another example is Harriet Scharnberg's article about the Associated Press's interactions with the Nazi government. Scharnberg's article, “Das A und P Der Propaganda: Associated Press und die nationalsozialistishch Bildpublizistik," examines how the American international news organization, Associated Press, was able to continue its reporting from Berlin until 1941. Scharnberg suggests that AP submitted to the German Editorial Control Law in 1935 in order to gain press privileges in Germany. This law required the news organization to provide photos of America for Nazis' propaganda purpose in exchange for remaining in Germany. ${ }^{28}$ Scharnberg analyzes how this specific news organization interacted with the Nazis, but does not provide an analysis on how the reporting appeared in newspapers. Thus, the general information provided to the American public about Europe's political situation remains unexamined.

The only other material on this period of media history is by the foreign correspondents themselves. Many of the correspondents wrote autobiographies and critical examinations of their experiences abroad. ${ }^{29}$ The sheer number of books written by them testifies to the level of selfimportance they had about their experiences during and after the war. Sigrid Schultz, for example, wrote a book published in 1944 on how Germany would attempt to wage war yet

\footnotetext{
successfully the true nature of the Nazi Party in their first two months at office. Ultimately, he criticizes the Times for not having foresight about the Nazi party in early 1933 and focuses more on editorials then the foreign correspondents themselves. See Gary Klein, "When the News Doesn't Fit: The New York Times and Hitler's First Two Months in Office, February/ March 1933," J\&MC Quarterly 78, no. 1 (Spring 2001): 127-149.

${ }^{28}$ Harriet Scharnberg, "Das A und P Der Propaganda: Associated Press und die nationalsozialistishch Bildpublizistik," Studies in Contemporary History (2016), accessed April 3, 2016, http://www.zeithistorishcheforschungen.de/1-2016/id\%3D5324.

${ }^{29}$ For a short list of foreign correspondents' books see Heald, Transatlantic Vista, 270-272.
} 
again. ${ }^{30}$ Another Chicago Tribune reporter, Donald Day, wrote an extensive testimonial on how his reports were censored during the second World War. ${ }^{31}$ Ultimately, these books can only be taken as the author's opinion of what happened instead of fact. Many of them were written after the correspondents returned from Europe. But, they do provide a window for current historians to understand how the correspondents viewed events in Europe and possibly functioned within their respective countries.

Consequently, the historiography on foreign news reporting is missing the larger picture of how foreign correspondents were able to communicate the news to their respective newspapers in this time period. The correspondents' methods of reporting are as important as the articles themselves, because they dictate what type of stories can be sent back to the newspapers. Thus, correspondents' choice of reporting methods is the foundation for any story in a newspaper. Most historians have avoid exploring this historical question, because it requires a detailed examination of correspondents across Europe. This lack of historical analysis has largely left the news workers absent from any discussion on the history of journalism. ${ }^{32}$ An examination of foreign correspondents' role in publishing articles from Europe starts to break down the idea that newspapers were solely driven by owners.

This thesis cannot examine all foreign correspondents stationed in Europe during the 1930s and 1940s. Such an examination would lack detailed analysis of the correspondents' reporting. My case study, therefore, focuses into two of the largest foreign correspondents' network directed by Chicago Tribune and New York Times, thus providing a wider perspective

\footnotetext{
${ }^{30}$ Sigrid Schultz, Germany Will Try Again (New York: Reynal \& Hitchcock, 1944).

${ }^{31}$ Donald Day, Onward Christian Soldiers: 1920-1942: Propaganda, Censorship and One Man's Struggle to Herald the Truth (Torrance, Calif: Noontide Press, 1982).

${ }^{32}$ Hanno Hardt, "Without the Rank and File: Journalism History, Media Workers, and Problems of Representation," in Newsworkers: Towards a History of the Rank and File, ed. Hanno Hardt and Bonnie Brennen (Minneapolis and London: University of Minnesota Press, 1995), 2.
} 
on the foreign correspondents' roles in news reporting and, more importantly, how their reporting appeared in the published newspaper. Therefore, my thesis provides a new, broader perspective on how foreign news reporting portrayed European events to the American public and starts to expand the history of journalism to include news workers.

This broader perspective helps to define more than the foreign correspondents' role in reporting the news from the 1930s to early 1940s. Hanno Hardt asserts that media historians have not explored "the relationship between media and change in American society and to analyze the role of individual actors, such as reporters, in this cultural and political process." ${ }^{, 33}$ This thesis explores how these correspondents set the tone for foreign reporting decades later. Each one of these reporters had some impact on how a reporter interacted with foreign governments to get the entire story about political, social, and economic events. All of this depended on the correspondents' gender, cultural knowledge, and ingenuity. The reporters who combined them all under the right condition became legends in mass media and set a standard for international reporting. This standard influenced how mass media portrayed foreign conflicts and the American perceptions of them years after the war.

I explore this broader perspective on foreign reporting through the Chicago Tribune's and New York Times's company archives. In the last 40 years, the Chicago Tribune made the papers of Colonel Robert McCormick open to the public. His papers contain a wealth of documents, such as letters and telegrams from all of their correspondents between 1914 to 1955 . Most of these documents were about correspondents' issues with reporting or McCormick's request for stories and reports on conditions in their respective countries, thus, providing insights into how

\footnotetext{
${ }^{33}$ Hardt, "Without the Rank and File," 10.
} 
Tribune's correspondents interacted with the company and their possible reporting conditions. ${ }^{34}$

The New York Times archive contains similar documents about their foreign correspondents; however, many of them focused on the daily routine of its Berlin News Bureau. ${ }^{35}$ Lastly, the Sigrid Schultz Papers are a crucial source since the collection contains all of Schultz's personal papers during her years of reporting in Germany. ${ }^{36}$ Her papers have valuable details on how she survived as a journalist in Germany throughout the 1930s and 1940s. Ultimately, all of these documents provide context to the main source of thesis, the published articles in the Chicago Tribune and New York Times. ${ }^{37}$

I approach this material in a systematic fashion in order to analyze the foreign correspondents' role in news reporting without simply recounting all of their stories. There are other ways of approaching this material, such as examining the newspapers' editorials; however, the focus would then not have been on the correspondents' actions and concrete situations. In each of the chapters, I analyze how the correspondents in Germany reported on significant events, under what conditions might have affected their reporting, and how their respective newspapers published their articles. Subsequently, I discuss in the same manner correspondents who may have reported on Germany, but resided outside of its borders. This is to explain any possible regional difference in reporting besides the fact they were outside of Germany's

\footnotetext{
${ }^{34}$ The papers of Colonel Robert R. McCormick are housed at the First Division Museum at Cantigny in Wheaton, Illinois. These papers were first used by Richard Smith Norton for his biography on Colonel McCormick published in 1990s. Others historians have used this archive to write biographies of the entire McCormick and Medill family.

${ }^{35}$ The company papers of the New York Times are located at the New York Public Library in New York City. Most of their records are from the $20^{\text {th }}$ century; however, they also have some records before Adolph S. Ochs brought the newspaper in 1896. The library also has the personal papers of the owner Arthur Ochs Sulzberger.

${ }^{36}$ The collection of Sigrid Schultz's papers is held at the Wisconsin Historical Society. These papers were donated to the society in the 1980s after Schultz passed away.

${ }^{37}$ Both of these newspapers are viewed through the ProQuest Database.
} 
borders. Lastly, I compare how individual reporters were able to communicate their news to their respective papers and what it meant for the American public. ${ }^{38}$

Based on the newspapers' articles and foreign correspondents' papers, I argue that the correspondents' reporting in published newspapers was a product of a highly intricate system of information distribution from Europe to the media outlets of the United States. Some of the European nations wanted to have total control over the flow of information and used tactics such as censoring communication, expelling troublesome correspondents from their countries, or limiting press briefings. The correspondents had to learn how to avoid issues with the European governments, while being able to send accurate news back home. However, the amount of information published was dependent on the opinions and political leanings of editors and newspaper owners. They were the ones who blended all of the articles together in order to present a coherent source of information for the American public and thus directly affected the narrative of the war. The main question for this thesis is what image of Europe was published in these newspapers based on the foreign correspondents' ability to work within both sides of this information system, the one in Europe and the one once their articles reached the United States.

I approach this question by examining how correspondents across Europe examine significant events relating to Germany over the course of three chapters. The first chapter argues that correspondents were already facing some governmental censorship in Germany by 1930. It also shows how the editors did not assign a lot of importance to articles from Germany. The second chapter describes how these new press rules became harsher from 1933 to 1939. It becomes apparent that after the Nazis consolidated in their power from 1933 to 1934, the press

\footnotetext{
${ }^{38}$ The public's reception of the news cannot be examined from the sources I collected for this thesis and also falls outside its scope.
} 
had to work under different rules. In many of the cases, the correspondents' reporting became directly connected with their safety.

The final chapter starts when the German army invaded Poland on September 1, 1939. The invasion changed the entire situation for foreign correspondents, because most of them were now reporting from a war zone. The correspondents had to make a choice about how far they were willing to risk their safety in order to report a story. This time period ends on December 11, 1941 when Germany declared war on the United States, which altered the entire situation for all correspondents in Europe once again. Ultimately, it ushered in the new journalistic era of governmental press and censorship. 


\section{CHAPTER II}

\section{THE JOURNALISTIC EVALUATION OF HITLER'S INTENT FROM 1930 TO 1934}

"There is no better way to avoid unfriendly propaganda than to let the press have free play. If stories appear censored people will believe propaganda."

-Geo Scharschug (Cable Editor for the Chicago Tribune) ${ }^{39}$

In the early 1930s, the Chicago Tribune's foreign correspondent for Germany, Sigrid

Schultz, and many other American correspondents realized that governmental censorship and expulsion were work hazards for any foreign reporters in Germany. On November 23, 1932, Schultz wrote a letter to Colonel Robert McCormick explaining how she had death threats in anonymous letters and a summons by the German Foreign Office Ministry, because of how she described Franz von Papen's actions in the newspaper. More importantly, the authors of the letters were upset about her lack of understanding Hitler's greatness in her articles for the Chicago Tribune. She recalled how she warded off the government's attempt to expel her by stating to the German official, "he was losing his time threatening me with expulsion, since my expulsion would make a dramatic story and leave no doubt in anybody's mind that Germany was run by Junker government." ${ }^{, 40}$ Schultz's statement showed that she had immense confidence that her position in Germany was secure. However, not all journalists were secure in their position nor had the power to protect themselves from their host governments.

This happened at the time when all of Europe and the United States were dealing with the fallout from the American stock market crash in October of 1929 and the collapse of the international trading market. The Western leaders were trying to keep their respective countries

\footnotetext{
${ }^{39}$ Mr. Scharchug to Sigrid Schultz March 27, 1933, Wisconsin Historical Center (WHC), Sigrid Schultz's Papers, Box 4, Folder 3.

${ }^{40}$ Sigrid Schultz to Robert McCormick November 23,1932, WHC, Sigrid Schultz's Papers, Box 4, Folder 8. The archive only had the carbon copy of this letter, which means it was not signed by Schultz. Most likely, she was the author of the letter, because the subject was about Herr von Papen. She wrote several articles about him a couple of days before the letter was dated. There was also no other Chicago Tribune correspondent that wrote about him.
} 
from falling completely into economic and political chaos. This led to most of the Western governments to withdraw from international politics at the start of the 1930s in order to address the economic fallout within their respective countries. Germany was hit particularly hard by the economic slump from the stock crash. The United States had heavily invested in Germany prior to the 1930s in order to help its economy and the rest of Europe recover from World War I, but the loans started to dry up at the beginning of 1930. Thus, Germany was thrown into dire economic troubles with no visible signs of improvement for the German people. Coupled with the weaknesses of the Weimar Republic, this led to the rise of radical nationalist groups, such as the Nazi party. ${ }^{41}$

March 27, 1930 marked the beginning of the Weimar Republic's downfall in Germany. This was the day that the moderate coalition broke apart, because the government could not agree how to move forward with the failing economy. Since no political party could gain a majority in the Reichstag, Germany was thrown into political chaos from 1930 to 1933 . This allowed the ultra-conservative right political parties to gain more influence in the government. Much of this can be contributed to their position of influence over President Hindenburg. This gave them the ability to push the President to use presidential decrees in order to drive Germany towards more of an authoritarian government. The various decrees took most of the power away from the Reichstag and invested it into the presidency, but still allowed Germany to masquerade as a democracy. ${ }^{42}$ This helped to set the stage in 1933 for the Nazis to destroy all of the other political parties, to form a coalition with the army, and to take the power away from Reichstag. This set Germany on the path to be a one party state. Hindenburg was the only person that stood

\footnotetext{
${ }^{41}$ Richard Overy, Origins of the Second World War, $3^{\text {rd }}$ ed., Seminar Studies in History, (Harlow, England and London: Pearson Longman, 2008), 9, 14.

${ }^{42}$ Richard Evans, The Coming of the Third Reich (New York: The Penguin Press, 2004), 247-251.
} 
in the Nazis' way of having complete control; however, he had little recourse to stop the Nazi Party. $^{43}$

When the Nazis began to gain power between 1930 and 1933, the American foreign correspondents found themselves increasingly watched and pressured by the German government and even in some cases, the United States' government, to censor their reporting. ${ }^{44}$ The journalists soon realized that they could not simply send stories from Germany, because of the possible repercussions from the German government. These journalists had to make a choice on how far they were willing to risk their careers and positions in Germany to send their uncensored articles. In contrast, the other journalists in Europe faced, at most, communication difficulties from their newspaper's shrinking budget and some governmental monitoring of cable services. Most of these problems were solved by changing communication services, which had no real impact on their reporting. Ultimately, the Chicago Tribune's and New York Times's foreign correspondents across Europe did not face the same difficulties in reporting the news, which influenced what articles were sent back to the newspapers from 1930 to 1933 . The factor that defined the correspondents' reporting was their reaction to the press changes by their host government.

At the start of 1931, foreign correspondents were gradually affected by new governmental press rules that attempted to influence and control their reporting back to the United States. This forced them to become creative with their communication methods to send relevant and uncensored articles back home, while at the same time abiding their hosts' governmental press rules in order to remain welcome in its borders. The foreign correspondents had to make a choice on how far they were willing to go for truth, while Europe was engulfed

\footnotetext{
${ }^{43}$ Evans, The Coming of the Third Reich, 367-374.

${ }^{44}$ Deborah E. Lipstadt, Beyond Belief: The American Press and the coming of the Holocaust 1933-1945 (New York: The Free Press, 1986), 6-7.
} 
into political issues. Essentially, not all correspondents were willing to push their luck as far as Sigrid Schultz in Germany in order to send their articles back home. Their individual answers defined what sort of information was provided to their editors and, subsequently, to the general American public in their daily newspapers.

I investigate this first by analyzing how the Chicago Tribune Berlin correspondent and then the New York Times Berlin correspondents functioned in Germany from 1930 to about 1932. The following sections examines the brief transitional period for these journalists, while the Nazis consolidated their power from 1933 to 1934. The correspondents' reactions are again highlighted by first examining the Chicago Tribune Berlin correspondent and then the Times correspondents. The main intention is to show the increasing difficulties that foreign correspondents encountered in Germany.

The Berlin News Bureau has often been defined as a challenge or near impossible assignments for foreign correspondents after Hitler and the Nazi Party consolidated power in Germany between 1933 and $1934 .{ }^{45}$ However, the foreign correspondents had difficulties with their reporting even before, as the German government kept a watchful eye over media in order to protect its image in Germany and in the world. ${ }^{46}$ Bernhard Fulda argues that these restrictions were an attempt to keep the media from undermining the legitimacy of the government through their partisan reporting. ${ }^{47}$ However, little is known about how the German government dealt with foreign correspondents before the Nazis.

\footnotetext{
${ }^{45}$ Laurel Leff, Buried by the Times: The Holocaust and America's Most Important Newspaper (Cambridge: Cambridge University Press, 2005), 50-51.

${ }^{46}$ An article in the Chicago Tribune discussed that the German government continued its attempts to censor Fascist news to the German public in July of 1931. There was no mention of the government worrying about censoring the foreign correspondents. See Chicago Tribune Press Service, "Germany Suspends Hitler's Paper in War on Fascisti," Chicago Tribune, ProQuest Historical Newspapers (PHN), July 13, 1931, 1. Richard Evans states that the press freedom was seriously compromised before the Nazis came to power. He identified foreign correspondents has affected by the press regulations. See Evans, The Coming of the Third Reich, 251-252.

${ }^{47}$ Bernhand Fulda, Press and Politics in the Weimar Republic (Oxford: Oxford University Press, 2009), 222-224.
} 
The experience of Chicago Tribune's Berlin correspondent, Sigrid Schultz, represents how the Weimar Republic attempted to shape the foreign correspondents' reporting, because her reporting in the early 1930s brought her into conflict with the German government. More importantly, her conflicts with the German government showed that the foreign correspondents' writing became enough of an issue for governmental restriction and regulation by the end of 1931. This means that the German government already began centralizing governmental control over information and the press at least one year before the Nazis gained full control over Germany.

Sigrid Schultz was uniquely qualified to cover Germany as a reporter, because most of her childhood and adult life was spent in Europe. When she was eight years old, her family moved from Chicago to France in 1901, because her father was a famous portrait painter in Europe. Most of her education took place in French schools and her father encouraged Schultz to become fluent in French, German, English, and Norwegian. He also personally schooled her in European upper class culture. ${ }^{48}$ Eventually, the entire Schultz family moved to her father's studio in Germany just before World War I broke out across Europe. The family was treated as possible foreign hostiles throughout the entire war, which required them to check in daily with the local German police. Schultz became the sole financial provider during the war, because her father was extremely ill and the demand for portrait paintings diminished. She was able to find work as a translator for foreign diplomats residing in Germany. This position provided an opportunity for her to meet and to form relationships with important diplomats and journalists, which paved the way for her to become one of the most knowledgeable journalists in Berlin. ${ }^{49}$

\footnotetext{
${ }^{48}$ Cynthia C. Chapman, "Psychobiographical Study of the life of Sigrid Schultz" (PhD diss., Florida Institute of Technology, 1991), 28-29.

${ }^{49}$ Chapman, "Psychobiographical Study of the life of Sigrid Schultz," 31-32.
} 
Her war job helped her to gain work as a translator for Richard Little, a Chicago Tribune foreign correspondent, who was temporarily reporting on the war's aftermath in Germany. He was impressed with her work to the point where he offered her a job as a foreign reporter for the Chicago Tribune in Germany ${ }^{50}$ By 1926, Schultz was in charge of the entire Berlin News Bureau for the Chicago Tribune; she was one of the first women given such a responsibility. ${ }^{51}$ She rose quickly through the media ranks, because her education and cultural knowledge gave her the tools to understand events in Germany on a better cultural level than most other reporters from the United States.

Schultz was not the only correspondent who spent an extensive period of time in Europe or in Germany. There were still plenty of veteran reporters from the 1920s, such as Larry Rue, on the Chicago Tribune's foreign staff. However, she was one of the few foreign correspondents who received a "byline" or authorship credit for her stories and spent most of her life in Europe. This does not mean that the other correspondents were not important. They did not receive a byline for their articles and were simply labeled as Chicago Tribune Press Service. These articles have no indication of ownership, which makes it near impossible to identify who wrote them. Most likely, Schultz received a byline, because of her natural abilities as a journalist. She had all of her fathers' contacts across Europe from his years as a painter for the wealthy Europeans, which provided an extremely wide base of informants and sources for her reporting. She also understood events from more of a European perspective. Thus, Schultz was in a good position to adapt and maneuver around the press regulations in Germany throughout the 1930s.

Hitler and the Nazi Party started to make it into Sigrid Schultz's reporting beginning in 1930, because of their political success in the Reichstag election in September of 1930. The

\footnotetext{
${ }^{50}$ Chapman, "Psychobiographical Study of the life of Sigrid Schultz," 32.

${ }^{51}$ Frederick S. Voss, Reporting the War: The Journalistic Coverage of World War II (Washington, D.C.: Smithsonian Institution Press for National Portrait Gallery, 1994), 3.
} 
Nazis gained almost 100 seats in the Reichstag, which made it a strong political force and, subsequently, they announced themselves as one to Germany and the rest of the world. ${ }^{52} \mathrm{~A}$ political party did not necessarily gain public notoriety by merely gaining seats in the Reichstag though. Case in point, not all foreign correspondents recognized Hitler and the Nazi party as a serious political threat, even with the large increase of seats. Many of the correspondents either briefly mentioned their presence in Germany or ignored them from 1930 to 1933. Schultz was one of the few who found Hitler troubling enough to provide warnings in her reporting.

By the end of 1932, she had written about 166 articles for the Chicago Tribune on Hitler's and the Nazi Party's rise in political power. ${ }^{53}$ She was one of the only Chicago Tribune correspondents who wrote about them from 1930 to 1932 at all. ${ }^{54}$ Early on, she reported that Hitler was more of a political nuisance with only some prospects of political strength. This changed between 1931 and 1932, because Hitler became a political threat towards the German government after gathering more political power from German public's support. In reaction, the government enforced press regulations to curb Hitler's influence on the German public. The government thought by minimizing his interaction with the public it would stop or diminish his political power. ${ }^{55}$ Therefore, the press had limited interactions with Hitler, but Schultz was not

\footnotetext{
${ }^{52}$ Evans, The Coming of the Third Reich, 257-259.

${ }^{53}$ This statistic was taken from ProQuest Chicago Tribune Historical database. It was calculated by using Sigrid Schultz as the author key term and Hitler as the subject term in order to narrow down the article entries.

${ }^{54}$ The other foreign correspondents who wrote about Hitler and his rise power were John Steele in London and Henry Wales. John Steele wrote an article about how the Soviet Union was combating German Fascism see John Steele, "Reveal Russian Plan to Combat German Fascisti," Chicago Tribune, PHN, October 2, 1930, 17. Henry Wales reported from Berlin in 1931 and most likely worked with Sigrid Schultz for this short time period. He wrote several articles on Germany's situation. For examples see Henry Wales, "Causes of Germany's Financial Crash Are Traced Since End of World War," Chicago Tribune, PHN, July 16, 1931, 2; Henry Wales, "German Crisis Spreads Over All of Europe: France Stands Pat on Demands," Chicago Tribune, July 15, 1931, 1. The other articles written about Germany in the Chicago Tribune were by the AP. They do not have bylines, which makes it difficult to trace the author. For an example see "New Party Would Nominate Royal German President," Chicago Tribune, PHN, July 5, 1931, B13.

${ }^{55}$ Fulda, Press and Politics in the Weimar Republic, 200-203.
} 
hampered by these rules. She was able to get a rare interview with Hitler on December 5, 1931 and provided some early insight into Hitler as German leader to the American public. ${ }^{56}$

Sigrid Schultz's early awareness of Hitler can be seen in her letters and reporting in 1930, which showed signs of a highly critical attitude towards him. She wrote a letter to Colonel McCormick on October 29, 1930, in which she described her opinion of Hitler and his current political stance. In the letter, she referred to Hitler as a "fascist bugbear" and poor at outmaneuvering the communists party in the Reichstag. ${ }^{57}$ Schultz suggested that Hitler did neither have the numbers in his party nor the ability to influence how the Reichstag operated in 1930, because the Communists outmaneuvered them with their 77 votes. She went on to describe how Hitler was only as dangerous as the last man who spoke to him, because that person directed his thoughts and ideas towards the audience. She thought that the German voters would start to question Hitler's political motivations, because he had an erratic message in his speeches. ${ }^{58}$ Her description of Hitler suggests that he was more of a nuisance with only some political power and influence, but possessed very little political skill to inflict any serious damage to Germany or to the rest of the world.

It is also important to note that Schultz was most likely free to write and report about any event in 1930 based on the letter. She did not write about press censorship or German governmental pressure for her to spin any articles. This is supported by her discussion of sources in her letter to McCormick, because she provided a lot of information about them and even

\footnotetext{
56 Sigrid Schultz, "Hitler Pledges to Pay Berlin's Debts to World: Nazi Chief Predicts He'll Be in Power Soon," Chicago Tribune, PHN, December 5, 1931, 3. Another foreign correspondent wrote an article for the New York Times that interviews with Hitler were difficult to get, because the German government was trying to curb his influence. See Guido Enderis, "Prussia Threatens Hitler's Expulsion: Leader of National Socialists Barely Escapes Deportation as "Undesirable Alien," New York Times, PHN, December 12, 1931, 1.

57 Sigrid Schultz to Colonel Robert McCormick October 29, 1930, WHC, Sigrid Schultz's Papers, Box 4, Folder 8. This letter was unsigned by Schultz. Most likely this letter was written by Schultz, because of the sources discussed within it. She was one of the few correspondents that could gain access to a high official like Brüning

${ }^{58}$ Sigrid Schultz to Colonel Robert McCormick October 29, 1930.
} 
though she did not mention their full names. She described their occupations and what information was given to her, which leads one to think she had no worry about the letter being read by German government officials and possible backlash. For example, she stated that German Chancellor Heinrich Brüning's secretary showed her a secret report given to German industrialists in order to help their trade negotiations with the Russians. ${ }^{59}$ She also discussed that Hitler's confidential aid told her Hitler found a legal loophole for him to get German citizenship even with being born in Austria. ${ }^{60}$ This sheer lack of vague language about her sources coupled with her negative comments about Hitler and her discussion of Brüning's governmental plans indicates that she had the ability to write freely about Germany for the time being.

It should be kept in mind that this letter was written in October of 1930 and early on in Hitler's rise to power. This was a time when no one knew the full extent of his potential for destruction and chaos, which meant there was little need for press regulations against him. Hitler also lacked the authority to enforce his will on the press. Schultz's commentary on Hitler showed her contempt for his political ideas with some concern about what he could do in Germany. This concern about Hitler's actions and potential political power remained a constant in her reporting, especially in the early 1930s. A couple of months before she sent the letter to Colonel McCormick, she had already written several articles about Hitler's rise to political power. ${ }^{61}$ Schultz's reporting should reflect this strong negative attitude towards the Nazis in her letter, however, the Tribune's editors changed her work and distorted her early insights on Hitler.

\footnotetext{
${ }^{59}$ Heinrich Brüning was appointed as the Chancellor of Germany in 1930. He was chancellor of the Weimar Republic for two years, but had to step down in May of 1932 after he could not retain mass public support for his leadership. His lack of public support can be contributed to his political isolationism from the rest of Germany. Evans, The Coming of the Third Reich, 250-252, 282-289.

${ }^{60}$ Sigrid Schultz to Colonel Robert McCormick, October 29, 1930, WHC, Sigrid Schultz's Papers, Box 4, Folder 8.

${ }^{61}$ For examples of her articles about Hitler's rise in power in 1930 see Sigrid Schultz, "Hindenburg Asks Peace Sacrifice Equal of War's: Appeals for Unity to Rebuild Fatherland," Chicago Tribune, PHN, March 16, 1930, 22 and Sigrid Schultz, "Reichstag Riots Feared; Berlin Masses Police," Chicago Tribune, PHN, December 3, 1930, 3.
} 
Most of her articles after the Reichstag election in September of 1930 focused on how the existing German government began to address Hitler and his promises as a political threat for Germany's future. These articles remained largely off the front page in 1930 expect for an announcement about the Reichstag election results on September $15,1930 .{ }^{62}$ There was also a front page article on December 4 that discussed the political reaction to the fights between the unemployed and Berlin police. ${ }^{63}$ The other articles had one of the earliest warnings that Hitler and the Nazis party had potential for destruction; however, they were published in the bulk of the paper. The reason for this cannot be fully explained, because of the lack of sources about editors. Most likely, it can be attributed to Nazi activism not being important enough for the front pages of American newspapers--nor should it have been at this early stage. The Nazis were simply a source of political tension and of some chaos for the Weimar government.

For example, her article about the Reichstag election and its aftermath was published on page five of the newspaper on September 16, $1930 .{ }^{64}$ At this time, the Communists, Nationalist Socialist Party (Nazis), and other German political parties were in a political battle for control over the Reichstag and Germany's future. ${ }^{65}$ The Nazi party and Communist party (KPD) also gained a large number of seats in the Reichstag, which required any governmental coalition to include them. This created a political dilemma for Germany, because the Nazi and Communist

\footnotetext{
${ }^{62}$ Sigrid Schultz, "Republic's Foes Make Big Gains in German Vote: Dictatorship Party Wins 103 Seats," Chicago Tribune, PHN, September 15, 1930, 1.

${ }^{63}$ Sigrid Schultz, "Jobless Stone Berlin Police; Shops Lock Up," Chicago Tribune, PHN, December 5, 1930, 1. ${ }^{64}$ Sigrid Schultz, "Von Hindenburg Defies Fascist Dictator Plan: Will Fight Plot to Wreck German Republic," Chicago Tribune, PHN, September 16, 1930, 5

${ }^{65}$ After the election of 1930, a political party did not have clear majority in the Reichstag to rule the government alone. Therefore, the political parties had to form a coalition in order to govern. The Nazis attempted to gain the political upper hand by getting votes through the destruction of the communists. See Evans, The Coming of the Third Reich, 259-265.
} 
party were on the opposite sides of the political spectrum. This meant a coalition was impossible as there were too many political parties on the fringe. ${ }^{66}$

Schultz's article highlighted this political dilemma in Germany to the American public. She discussed how the Communists and Nationalist Socialist Party differed over political ideals. She also explained that this meant any attempt by the National Socialist party to form a coalition government would be opposed by their political enemies in the Center and DNVP. ${ }^{67}$ She even described how President Von Hindenburg picked a side through his statement, "let it be known tonight that he would fight to the last ditch any attempt of the Hiterlites to usurp power.",68 Schultz's article suggest that the two political parties would not agree on anything and attack each other's political agendas and be source of tension. ${ }^{69}$

Another one of Schultz's article about the German political situation published on October 13, 1930 also received similar treatment by it being placed on page four of the newspaper. She reported that the German political parties were resorting to violence in order to secure their respective position of power. In early October, the German Social Democrats held a demonstration to show the "fascists" their level of strength. According to the article, this demonstration was led by Dr. Paul Loebe, the Social Democratic President of the Reichstag. This erupted into fist fights on the street and the police arrested 38 people. Schultz also reported that the "fascists" reacted to the fighting by defying the Prussian laws and wearing their brown shirts in the Reichstag. ${ }^{70}$ A clear indication of political unrest was emerging from Germany in

\footnotetext{
${ }^{66}$ Evans, The Coming of Third Reich, 259-265, 275-79.

${ }^{67}$ Schultz, "Von Hindenburg Defies Fascist Dictator Plan."

${ }^{68}$ Schultz, "Von Hindenburg Defies Fascist Dictator Plan."

${ }^{69}$ Schultz, "Von Hindenburg Defies Fascist Dictator Plan."

70 Sigrid Schultz, "100,000 Shake Fists at Fascist Party in Berlin: Defy Hitler on the Eve of Reichstag Opening," Chicago Tribune, PHN, October 13, 1930,4.
} 
Schultz's reporting; however, the page placement showed that Chicago Tribune's editors thought that other news, such as New York gang violence, was more important at the time. ${ }^{71}$

This early political unrest helped Hitler to gain massive popular support among the middle-class voters by the beginning of 1932 . These voters were becoming more radicalized and discontented with the Weimar Republic, because of its failure to improve the low standard of living. ${ }^{72}$ Schultz's interview with Hitler in December of 1931 is an illustrative case of her early anxiety over his growing political power. In the article, she introduced him as "the 'bogey man' of Germany's finances" and "leader of the National Socialists, otherwise known as fascists." These terms are not typically used to describe a possible future leader that wants peace and prosperity. In fact, it almost projected a sense that Hitler could be a nightmare for at least Germany. Schultz's interview and description of Hitler are almost acting as an initial warning to the US citizens about Hitler's true intent for Germany's future.

Schultz supported this portrayal in the interview by discussing how the Nazi party was the strongest political party in Germany and how it gave Hitler immense confidence in himself. Schultz went as far as stating, "Hitler is convinced that absolute power will be his in Germany in the course of a year at the latest." She even used the subtitles such as "Nazi Chief Predicts He'll be in Power Soon" and "My Will Be Done." "74 This may not have been intentional, but with the last subtitle Schultz made a reference to the Lord's Prayer, possibly creating an image of Hitler as thinking of himself like a god. This was made worse when she coupled it with his quote, "The communists are the scourge of nations. The war we are carrying on is not a platonic war, it is a

\footnotetext{
${ }^{71}$ Chicago Tribune, PHN, October 13, 1930, 1.

${ }^{72}$ Evans, The Coming of Third Reich, 281-282.

${ }^{73}$ Schultz, "Hitler Pledges to Pay Berlin's Debts to World."

${ }^{74}$ Schultz, "Hitler Pledges to Pay Berlin's Debts to World."
} 
bloody one. ${ }^{, 75}$ Schultz may not have intended this for her interview to be an early warning, but it painted Hitler as a strong political presence in Germany who was obsessed with gaining more power by any means necessary. Unfortunately, the interview was tucked away on page three of the newspaper next to a story about two sets of twins being born. The placement makes it more of a human interest story instead of a serious analysis of potential leader of Germany.

Schultz's conclusion is the polar opposite to the other famous interview of Hitler by New York Post and the Philadelphia Ledger foreign correspondent Dorothy Thompson, which was published in Cosmospolitan in March 1932. ${ }^{76}$ Peter Carlson argues that Thompson described Hitler as "much-hyped demagogue [who] was too peculiar to be a threat to Germany, much less to the United States." ${ }^{, 77}$ He suggests that Thompson was not "prepared for the man she met, who seemed so.. pathetic." ${ }^{78}$ Thompson's interview with Hitler was done around the same time as Schultz's, but was published on a later date. It can be said that Thompson grossly underestimated Hitler, because he took control of Germany within a year of the interview. She spent much of the next decade attempting to fix her reporting mistake by writing critical articles about Hitler and the Nazi Party, which eventually got her the honor of being the first journalists expelled from Germany in $1934 .{ }^{79}$ Evidently, Schultz, who had helped Thompson to get the interview with Hitler, had a different understanding of Germany's political situation from 1930 to $1932 .{ }^{80}$ Both

\footnotetext{
${ }^{75}$ Schultz, "Hitler Pledges to Pay Berlin's Debts to World."

${ }^{76}$ Historian John Maxwell Hamilton describes Dorothy Thompson as one of the ablest journalists in Europe. She was a graduate of Syracuse University in 1914. She ventured over to Europe during one of the largest waves of American journalists in 1920. Like Schultz, she became the chief of the news bureau in 1925. She left Germany for a short time in order to spend time with her husband Sinclair Lewis in the United States. She came back to Germany in 1930, because of the rise in fascism. After her interview in 1931, she spent most of her career trying to fix her mistake with her perception of Hitler's power. Her critical articles of Nazis Germany led to expulsion in 1934. For more information, see John Maxwell Hamilton, Journalism's Roving Eve: A History of American Foreign Reporting (Baton Rouge: Louisiana State University Press, 2009), 265-276. For more biographical information on Dorothy Thompson see Peter Kurth, American Cassandra: the Life of Dorothy Thompson (Boston: Little, Brown, 1990).

${ }^{77}$ Peter Carlson, "Dorothy Thompson Underestimates Hitler," American History 50, no. 4 (Oct 2015): 17.

${ }^{78}$ Carlson, "Dorothy Thompson Underestimates Hitler," 16.

${ }^{79}$ Carlson, "Dorothy Thompson Underestimates Hitler," 17.

${ }^{80}$ Hamilton, Journalism's Roving Eve, 276.
} 
women were journalists, but Schultz has the experience in Germany to write a warning about Hitler's political power.

Their different conclusions emphasize the original question of how Schultz was able to report from Germany with the emerging governmental press rules. The fact Schultz even received a rare interview with Hitler is a testament to her abilities as a reporter. A couple of days after Schultz's interview with him was published on December 5, a New York Times article stated that "Hitler barely escaped expulsion from Germany today when he attempted to stage another interview with foreign correspondent as a retort to Chancellor Brüning's radio castigation." ${ }^{81}$ This article does not provide any indication of how Hitler would be expelled or the identity of the correspondent. It may have been Schultz's interview that triggered Hitler's drive and the German government's reaction, but it does suggest that the government was attempting to curb Hitler's influence on the media and his ability to political attack the current government. The threats of expulsion also showed to what length the government was willing to protect the peace and their rule in Germany.

This New York Times article suggested that Sigrid Schultz and the rest of the foreign correspondents in Germany experienced little or no harassment from the German government for their reporting until the end of 1931. It was more of a question on how the foreign correspondent evaluated the political situation in Germany. Clearly, Schultz and Thompson initially had two different views over Hitler. Most likely, Schultz was able to get the interview, because of her connections in Germany and her negative tone matched the German government's press goals with Hitler. The issue for Schultz at this early stage was that most of her articles about Germany's political situation were not seen as front-page material by editors in Chicago. One

\footnotetext{
${ }^{81}$ Guido Enderis, “Prussia Threatens Hitler's Expulsion,” New York Times, PHN, December 12, 1931, 1.
} 
cannot definitively determine why they did not appear on the front page expect for the fact other news was seen as more important at the time. ${ }^{82}$

The New York Times reporters in Germany faced a similar situation with their editors, however, on average more stories about Germany’s general situation appeared on the front page. ${ }^{83}$ This newspaper had more reporters located in Germany at the start of 1930 , but most of them did not receive a byline for their articles. ${ }^{84}$ The main reporter for the New York Times in Germany with a byline was Guido Enderis, who became chief of the Berlin News Bureau in 1930. The Times had hired Enderis in 1928, because they thought he would be culturally adaptable to Germany. He was Swiss-born and, more importantly, had experience reporting from in Germany during World War I. Laurel Leff argued that the issue with Enderis's reporting was his extreme German sympathies, which became apparent to his editors by $1935 .{ }^{85}$ Leff's argument is lacking an analysis of his reporting from 1930 to 1933 before Nazis took control of Germany. Enderis's sympathy for Germany does not come through in his reporting from 1930 to 1931. His reporting is comparable to Sigrid Schultz's reporting with only some writing style differences in how he critically described the events unfolding in Germany.

Enderis's reporting on the election results for Germany in September of 1930 is an illustrative case in point. In one article on September 15, he discussed how the election was a surprise for everyone, but he devoted very little space to what the election results meant for

\footnotetext{
${ }^{82}$ Sigrid Schultz only had 35 front articles from 1930 to 1931. For examples of them see Sigrid Schultz, "Battle Rioters in Prussia," Chicago Tribune, PHN, August 9, 1931; Sigrid Schultz, "Paris Becomes Germany's Ally in Trade Fields," Chicago Tribune, PHN, September 29, 1931, 1; Sigrid Schultz, "Berlin Police Raid Student Dueling Orgy," Chicago Tribune, PHN, November 27, 1930, 1.

${ }^{83}$ For examples of front page articles see Guido Enderis, "Bruening Staves off Moratorium Moves by Reichstag Foes," New York Times, PHN, October 29, 1930, 1; Guido Enderis, "Bruening is Victor in Reichstag Voting; Disorders Continue," New York Times, PHN, October 19, 1930, 1; Guido Enderis, "Reich to End Dole, Conscript Jobless; League is Disturbed," New York Times, PHN, September 26, 1930, 1.

${ }^{84}$ For examples of this type of article see "Germany Denies Meddling in China," New York Times, ProQuest Historical Newspaper, January 11, 1930, 6; and "Citizenship for Hitler: He May Be Naturalized to Stay in Germany," New York Times, ProQuest Historical Newspaper, July 15, 1930, 8.

${ }^{85}$ Leff, Buried in the Times, 55.
} 
Hitler and his party. Rather, he focused on providing an overview of the political parties involved in the election. The only issue he discussed at length was how the fascists and communists could join together as a group in order to block any unfavorable laws from passing. There were also about three short paragraphs that were devoted to Hitler's message and support base, but little in way of an analysis. A small glimpse of it was in Enderis's description of how Hitler attracted his followers. He wrote, "Herr Hitler also kindled the imagination of millions of young voters by the fiery nature of his oratory, while the more mature electorate was fed with anti-Semitic, anti-reparations and anti-parliamentary haranguing." ${ }^{\prime 86}$ The subtitle for this article provided some indication of the fascists' goals and what Enderis thought about them, which was "Fascists Oppose the Young Plan- Stand for Extreme Nationalism and Curb on Foreigners." His article provided a brief assessment of Hitler's intentions and some facts on his rise to power in the German government. Many of his other articles followed a similar pattern with a couple of exceptions. ${ }^{88}$

One of the rare articles that Enderis wrote exclusively on Hitler and the Nazi party was published on the New York Times's front page on September 26, $1930 .{ }^{89}$ This article was published shortly after Reichstag election of September 14, 1930, which was when the Nazi Party received 6.4 million votes and seated 107 deputies as the second largest party. ${ }^{90}$ Enderis's front-page article gave a good indication of Hitler's political ideas. It was entitled "Hitler Would

\footnotetext{
${ }^{86}$ Guido Enderis, "Fascists Make Big Gains in Germany, Communists Also Increase Strength as Moderates Drop in Reich Election," New York Times, PHN, September 15, 1930, 1.

${ }^{87}$ Enderis, "Fascists Make Big Gains."

${ }^{88}$ For examples see Guido Enderis, "Bruening Staves off Moratorium Moves by Reichstage Foes," New York Times, PHN, October 29, 1930, 1; Guido Enderis, "Moderates Shape Coalition to Hold Power in Germany," New York Times, PHN, September 15, 1930, 1.

${ }^{89}$ Guido Enderis, "Hitler Would Scrap Versailles Treaty and Use Guillotine," New York Times, PHN, September 26, $1930,1$.

${ }^{90}$ This was a large political usurp in Germany, because it indicated a polarization of its politics. Many of the middle political parties lost some of their support, which made them political weak. For more information, see Klaus Fisher, Nazi Germany: A New History (New York: Continuum, 1998), 227-228.
} 
Scrap Versailles Treaty and Use Guillotine," which was most likely intended to capture the readers' attention, because the word guillotine is often associated with mass murder and political revolution. ${ }^{91}$ Enderis' description on Hitler's testimony during his trial for treason against the German government in 1924 gave the reader a base in his political ideology. Enderis quoted Hitler as saying, "We National Socialists refuse to recognize the treaties concluded over the heads of the German people as of permanent duration and also propose to fight the war guilt lie."${ }^{92}$ This description clearly described Hitler's early political ideology in plain language, and pointed about his hindsight for Germany

His other articles about Hitler and the Nazi party focused on the many feuds with the other German political parties, and the political violence that followed. ${ }^{93}$ In an article published on October 15, 1930, Enderis described an interesting situation when Hitler was being accused of inciting riots in Berlin that damaged the business district. ${ }^{94}$ This article was written a couple of days after the Reichstag meet for the first time since the election in September of 1930. The Nazis incited political chaos throughout Berlin by wearing their brown shirts in parliament and defying the law. Joseph Goebbels also organized the first attacks on Jewish businesses, while other Nazi supporters fought with communists in the streets. ${ }^{95}$

In the October article, Enderis quoted Hitler as denying any connection to these riots by challenging how the police handled the rioters and suggested that communists were provoking them in order to discredit the Nazi party. Enderis described this further by saying, "To him [Hitler] the two extreme radical parties, the National Socialists and the Communists, constitute

\footnotetext{
${ }^{91}$ Enderis, "Hitler Would Scrap Versailles Treaty and Use Guillotine."

${ }^{92}$ Enderis, "Hitler Would Scrap Versailles Treaty and Use Guillotine."

${ }^{93}$ For examples see Guido Enderis, "Dr. Bruening Warns Reichstag Deputies," New York Times, PHN, December 6, 1930, 10; Guido Enderis, "Bruening Succeeds in Forming Cabinet," New York Times, PHN, October 10, 1931, 8; and Guido Enderis, “"Nazi' Vote Alarms Reich Government," New York Times, PHN, November 17, 1931, 9.

${ }^{94}$ Guido Enderis, "Hitler Hints Reds Led Riot in Berlin," New York Times, PHN, October, 15, 1930, 14.

${ }^{95}$ Fisher, Nazi Germany, 229.
} 
symbols of the coming development, a Bolshevistic or a Nationalist Germany."96 This article described the political unrest in Germany, especially between the Nazis and Communists, and did not point towards a bright future. Enderis's articles showed very little favoritism towards Hitler and his role in Germany's political difficulties. If Enderis had been pro-Nazi, he would have described a more positive future for Germany with the Nazi Party. ${ }^{97}$

Most likely, Enderis was also actively trying to get more information about Hitler; however, the German government was attempting to curb Hitler's potential power by denying him a public platform to spread his ideas in Germany. On December 11, 1931, Enderis described how Hitler was denied the chance to give an interview to a foreign correspondent by the German government. ${ }^{98}$ The German government was also becoming worried about how the press could undermine its economic reform plans from 1931 to $1932 .{ }^{99}$ Enderis's reporting may have also been influenced by the New York Times 's clamp down on stories about anti-Semitism, in general, as Hitler rose in power. Leff argues that the Times banned the use of any letters to the editor about Hitler's rise in power, because the owner did not want his newspaper to become a running commentary of the Jews' situation in Germany. This would make the newspaper appear to focus only on the Jewish issue, because the owner was also Jewish. ${ }^{100}$

Nevertheless, the other New York Times journalists without a byline in Germany did not seem to pay much attention to the policy or the German government. They almost reported

\footnotetext{
${ }^{96}$ Enderis, "Hitler Hints Reds Led Riot in Berlin."

${ }^{97}$ For examples see Guido Enderis, "Reich Cabinet Stays; Socialists to Aid It," New York Times, PHN, September 17, 1930, 1; Guido Enders, “Bruening Dominant in Reich After Year: Germany's Strong Man,” New York Times, PHN, April 5, 1931, 51; Guido Enderis, "Germany Prepares to Crush Plotters," New York Times, PHN, November $30,1931,11$.

${ }^{98}$ Guido Enderis, “Prussia Threatens Hitler's Expulsion: Leader of National Socialists Barely Escapes Deportation as "Undesirable Alien,” New York Times, PHN, December 12, 1931, 1.

${ }^{99}$ Fulda, Press and Politics in the Weimar Republic, 170.

${ }^{100}$ Leff, Buried by the Times, 30-32.
} 
entirely on Hitler and his rise in political power from 1930 to $1932 .{ }^{101}$ These articles were more detailed and explicit about discussing Hitler's intent for Germany's future. An article published on September 30, 1930 provided their readers with a complete discussion on Hitler's political, economic, and social goals for Germany. For example, it stated one of Hitler's goals was “a nation-wide campaign to disfranchise or drive from Germany all the Jews." ${ }^{\text {102 }}$ It also goes on to describe how "all journalists must be German citizens, and all productions of art and literature contrary to the principles of true Germanism are to be suppressed." ${ }^{103}$ This statement foreshadowed the Nazis' attitude towards journalists after they gained full control over the government between 1933 and 1934.

Unfortunately, most of these articles were placed in the back of the newspaper. These reporters, including Enderis, had only about 49 front page articles and 104 editorials about Hitler and the Nazi party from 1930 to $1931 .{ }^{104}$ The lack of front page news articles cannot be explained by a lack of articles from foreign correspondents or what was published in The Times. It also cannot be clarified based on the archival sources, because the lack of communication among editors and correspondents. Like the Chicago Tribune, it can only indicate that Hitler and the Nazi party were not on the newspaper's front page for lack of importance instead of a lack of reporting.

The lack of front page articles does not change for the New York Times's or Chicago Tribune reporters until late 1931. This can be contributed to Hitler gaining more political power in Germany from the political unrest, which caused the Western governments to be concerned.

\footnotetext{
${ }^{101}$ According to the ProQuest historical database, there were about 500 articles not written by Guido Enderis that appeared in the New York Times about Germany and its election.

102 "Fascists Glorify Pan-German Ideal," New York Times, PHN, September 15, 1930, 2.

103 "Fascists Glorify Pan-German Ideal," 2.

${ }^{104}$ This statistic was taken from ProQuest New York Times Historical newspaper database by entering in Germany and Hitler or Nazis.
} 
Hitler also acquired a full time foreign press chief, Ernst "Putzi" Hanfstaengl, in early 1932 to communicate with foreign press. ${ }^{105}$ Therefore, the correspondents had more access to information channels and their articles became more relevant news for the West. ${ }^{106}$ In 1932, Hitler's and the Nazi Party's media image across the world became an important factor for their rise to power, which meant they needed to project a strong and stable persona for the other Western countries. This meant that the correspondents' press freedom in Germany also began to change after 1931.

The Reichstag was slowly descending into political violence and chaos by the end of 1931, because of political tensions caused by the polarized electorate. This situation became even more precarious in 1932, because Germany had a presidential election with Paul von Hindenburg approaching his final year of his seven-year term. Most Western nations were watching to see who would emerge from not only the violence, but also the campaign. At the age of 84 , Hindenburg decided to run, yet again, in order to stop Hitler from gaining more momentum and posing a threat to the standing government. This developed into run off for votes between Hitler, Hindenburg, and Ernst Thälmann of the Communist Party. Hitler was not able to unseat Hindenburg from the presidency; however, he continued to gain strength and political influence with him earning 37 percent of the vote. ${ }^{107}$ The foreign correspondents were in the midst of this political battle that heavily influenced the direction of Germany's future, but were they able to publish detailed stories about the tension among political parties as their freedom of the press slowly disappeared?

\footnotetext{
${ }^{105}$ David George Marwell, "Unwonted Exile: A biography of Ernst "Putzi” Hanfstaengl” (PhD diss., State University of New York, 1988), 109-112.

${ }^{106}$ Peter Conradi, Hitler's Piano Player: The Rise and Fall of Ernst Hanfstaengl, Confidant of Hitler, Ally of FDR (New York: Carroll \& Graf Publishers New York, 2004), 83-86.

${ }^{107}$ Evans, The Third Reich Coming to Power, 275-283.
} 
Sigrid Schultz was one of the first foreign correspondents in Germany to mention any sort of difficulties with her reporting after the presidential and Reichstag elections in early 1932. ${ }^{108}$ She was the journalist that used her political connections to get an interview with Hitler before 1931 and showed a negative attitude towards the Nazi Party. ${ }^{109}$ On November 23, 1932, Schultz mentioned in a letter to Colonel McCormick how the German Foreign Office was pressuring her to "color news" in favor of Herr von Papen. ${ }^{110}$ In May of 1932, Hindenburg appointed his aristocrat friend, Papen, as the new Reich Chancellor and successor to Brüning, because he thought Brüning's government was too unpopular. Papen was known for his conservative values and his anti-democratic policies. Papen attempted to align himself with the Nazis in order to gather mass support for his agenda, and decided to influence Hitler with a political concession of dissolving Reichstag in July for another election in order to gain his support. $^{111}$

On July of 1932, the SA caused a mass riot in Altona near Hamburg in order to influence the election. Papen used these riots as an excuse to disband the Prussian state government, because he claimed that it could not handle the violence. This dealt a crushing blow to Weimar Republic as a democracy, because the German government became more centralized. This did not quell the political chaos in the Reichstag, which led to Papen requesting it to be dissolved and new elections scheduled for November 6. Many of the political parties including the Nazis

\footnotetext{
${ }^{108}$ Most of the other articles were written by the Chicago Tribune Press Service or the Associated Press, which does not have a byline. For examples of these articles, see Associated Press, "Hitler Declares "Hour at Hand" to Squelch Reds," Chicago Tribune, PHN, June 25, 1932, 9; and Chicago Tribune Press Service, "Berlin Spurns 'Secret Deal' as Price of Pact," Chicago Tribune, PHN, July 12, 1932, 1. One other article appeared in the newspaper by Cousin Eve, who received an interview with Von Papen. This interview was focused on social aspects of his life. For more information, see Cousin Eve, “An Interview with Germany's Franz von Papen,” Chicago Tribune, PHN, August 21, 1932, G1.

${ }^{109}$ For more information about Schultz's interview, see page 25 to 28.

${ }^{110}$ Sigrid Schultz to McCormick November 23,1932.

${ }^{111}$ Fisher, Nazi Germany, 244-246.
} 
were upset about having to pay for yet another election. ${ }^{112}$ Schultz's letter to McCormick was written a couple of weeks after this Reichstag election, which was when Papen was the most unpopular. ${ }^{113}$ Schultz was most likely pressured by the German government, because Papen needed a good media image in order to help keep control of Germany. This was one of the signs that the German government attempted to centralize its control over the domestic and foreign press for its own needs and purposes.

Richard Evans argues that Papen attempted to shape the German press's account of these riots by banning democratic newspapers. This would have helped him to gather more support in Germany. Evans did not mention anything about foreign newspapers and their correspondents' reporting of these events. ${ }^{114}$ Schultz's letter suggests that the German government did not want these riots discussed in the American press unless it was written in a positive light, justifying Papen's actions. However, Schultz did not pay much attention to the German government's wishes in her articles and showed how the government had little control over the foreign press in 1932.

Schultz wrote a couple of articles immediately after Reichstag election in November that showed her negative opinion of Papen's leadership. On November 6, 1932, Schultz published an article that described how "Germany found itself engaged in a bitter four cornered political fight for seats in the [R]eichstag." 115 She identified the four as Republicans, Chancellor von Papen, Adolf Hitler, and the Communists. She discussed how "Von Papen is preaching respect for law, yet his high handed dealings with the Prussian government and his violation of the rulings of the

\footnotetext{
112 Evans, The Third Reich Coming to Power, 284-289.

${ }^{113}$ Sigrid Schultz to McCormick on November 23,1932.

${ }^{114}$ Evans, The Third Reich Coming to Power, 284.

115 Sigrid Schultz, "Germany Votes Today; 4 Parties Fight for Power: Fate of Republic at Stake in Bitter Battle," Chicago Tribune, PHN, November 6, 1932, 11.
} 
Supreme Court have resulted in a conflict with strong forces in Prussia and Bavaria." ${ }^{116}$ In her article on November 13, 1932, Schultz argued that Von Papen's governing style was equal to a dictatorship. She even described that Von Papen was losing the support of Hitler and the Nazi party, because his actions were seen as dictatorship to most of Germany. ${ }^{117}$ Clearly, Schultz had a negative attitude towards Papen's leadership and lacked respect for his agenda. Papen's pressure evidently did not influence her into writing any positive news stories about his leadership in Germany.

Both of Schultz's articles were describing the problems of Papen's government, which hurt his and Germany's image on the international stage. More importantly, it suggests that the German government had attempted to influence foreign correspondents even before Hitler rose to power, but had little to no success. This governmental pressure can be dated back to at least to the end of 1931 as previous discussed with limited press access to Hitler. ${ }^{118}$ Schultz also mentioned in her letter on November 23, 1932 that the German Foreign Office had a department that took care of the foreign press and summoned them for significant infractions against the German government in their reporting. Most likely, this department had very little power in 1932, because Schultz was able to fend them off by stating that the ministry "was losing his time threatening me with expulsion, since my expulsion would make a dramatic story and leave no doubt in anybody's mind that Germany was run by Junker government." ${ }^{119}$ However, this does not mean that other American foreign correspondents had such an easy experience with the German government or even reacted in the same manner as Sigrid Schultz.

\footnotetext{
${ }^{116}$ Schultz, "Germany Votes Today; 4 Parties Fight for Power: Fate of Republic at Stake in Bitter Battle,”.

${ }^{117}$ Sigrid Schultz, "Von Hindenburg Clings to Papen as his Dictator: President Is Expected to Dissolve New Reichstag," Chicago Tribune, PHN, November 13, 1932, 14.

${ }^{118}$ For more information about the early interviews with Hitler, see page 28 to 31 .

${ }^{119}$ Sigrid Schultz to McCormick November 23,1932.
} 
The New York Times reacted to the political chaos in Germany by hiring a British journalist, Fredrick Birchall, as chief Foreign Correspondent of Europe in 1932. Birchall traveled around all of Europe, but focused on reporting events from Germany. At the time of his employment, he was already in his sixties and had worked as an editor for The New York Times in London from 1926 to 1931. He was known for his dedication to his employer and work, because he would sleep in the office so he would not miss a phoned in story. In 1934, Birchall was awarded a Pulitzer prize for his observant coverage on the Nazi regime. His excellent reporting was often credited to his understanding of the New York Times 's fragile position in Germany from it being owned by a Jewish family. The German Jewish community's situation was progressively becoming worse and the American Jewish community expected the Times to publicize or be accused of white washing the situation in Germany. ${ }^{120}$ Therefore, the Times needed a journalist that could report the news about the Jewish situation in Germany without making it appear as the sole focus of the paper and protect its reputation.

Birchall's reporting in 1932 showed that he had an ability to balance promoting awareness of events in Germany without glossing over important facts, but it does not always come through in each of his articles. This can be seen in his description of Germany's presidential and general Reichstag elections throughout 1932. One of his first articles published on March 13, 1932 was titled, "Republic is in Balance," with subtitles of "Opponents of Hindenburg Seek to Overthrow Democratic Rule, All of Europe is Worried, Future Courses of Half Its Nations Will be Affected by the Outcome."121 His title fostered awareness that not only Germany had a stake in the upcoming presidential election, but also Europe and the United States. Birchall was intent not only to catch all of Europe's eyes, but also in the United States,

\footnotetext{
${ }^{120}$ Leff, Buried in the New York Times, 52-53.

${ }^{121}$ Frederick T. Birchall, "Republic is in Balance," New York Times, PHN, March 13, 1932, 1.
} 
when, he wrote, "the result will affect the future course of half the countries of Europe, and its repercussion cannot but reach distant America." ${ }^{122}$ In the rest of his article, Birchall explained how this election would influence the Germany's political landscape. One of his foci was to explain why the working class was discontent with the current government. ${ }^{123}$ This article was intended to showcase the importance of the potential, political chaos brewing in Germany. However, most of his other articles in 1932 did not follow this pattern of a detailed political and opinionated discussion.

Most of his other articles in 1932 did not take on such a crusade, but Birchall did not provide an explanation for any change in his reporting. It could have been that Birchall did not think the situation called for it anymore, because after the first presidential election in early March of 1932 no party had a majority in the Reichstag and Hindenburg barely edged out Hitler for the presidency in the run-off election a month later. ${ }^{124}$ Birchall may have thought Hitler was only a minimal threat at this point, because the presidency was secure. Therefore, it makes sense that most of his other articles focused on providing information about the political fallout, party violence, and Germany's future instead of warning about Hitler. ${ }^{125}$

As a case in point, Birchall's article on March 20, 1932 described the Nazi Party as still having a strong support base, but politically plateauing in its power for the next couple of years. He described Germany's political situation as a "season for considering the danger from which

\footnotetext{
${ }^{122}$ Birchall, "Republic is in Balance." This article was published after the first presidential election in March of 1932. There was no clear majority among the candidates in Germany. This required Germany to hold a runoff election in order to have a candidate with the majority of votes. For more information, see Fisher, Nazi Germany, 226-228.

${ }^{123}$ Birchall, "Republic is in Balance."

${ }^{124}$ Evans, The Coming of the Third Reich, 279-281.

${ }^{125}$ For examples of his articles see, Frederick Birchall, "Hilerites Push on; Win State Election," New York Times, PHN, June 6, 1932, 7; Frederick Birchall, "Another Stalemate is Likely in Germany," New York Times, PHN, July 25, 1932, 5; Frederick Birchall, "Election Gives Reich New Kind of Regime," New York Times, PHN, August 2, $1932,1$.
} 
she has temporarily escaped and the extent to which it will last during the next few years."126 This showed that Birchall clearly thought the recent president election indicated Hitler was unable to gain enough public support to be dangerous. Essentially, Birchall saw Hitler's loss and the future run-off election as a sign of the Nazis losing public support. He described the Nazis as "it is probably wrong to call it a "party"; it is just a well-organized[,] semi-hysterical assembly of the discontented- has come out of this election with a depleted exchequer but with enthusiasm and hopes of its devotees almost undimmed." ${ }^{, 27}$ Birchall did not ignore the fact that the Nazi Party was strong, because he clearly stated that Hitler posed a threat before the presidential election in March of 1932. He presented the idea that the Nazis were not yet able to grain any significant political strength in the German government by the lack of support and votes in the presidential election.

Nevertheless, Birchall was not the only reporter in the New York Times 's Berlin News bureau. The news chief, Guido Enderis, still reported heavily on events in Germany, and the gist of his articles largely remained unchanged from 1930 to 1931. For example, his article published on February of 1932 described Hindenburg's announcement of his campaign for presidency as clearly drawing the political lines in Germany. He stated that "Hindenburg has brought confusion to the reactionary and Fascist forces, and competent political observers predict he will be reelected."128 This quote indicated that the President was the candidate for the Weimar Republic, because of his fighting for a system that only caused problems for Germany. ${ }^{129}$ Therefore, Enderis' reporting was providing a sense of what was happening in Germany by describing the

\footnotetext{
${ }^{126}$ Frederick T. Birchall, “Germany’s Faction Begin 'Truce of God,” New York Times, PHN, March 20, 1932, E3.

127 Birchall, "Germany's Faction Begin 'Truce of God."

${ }^{128}$ Guido Enderis, "Hindenburg Agrees to Seek Re-Election; Nazis to Fight Him,” New York Times, PHN, February $16,1932,1$.

${ }^{129}$ Enderis, "Hindenburg Agrees to Seek Re-Election."
} 
deep political divides emerging in Germany. More importantly, this article appeared on the front page of the New York Times and it was not a unique case.

The New York Times did not only hire Birchall in 1932 to cover the events in Germany. The bylines of several other correspondents appeared in the newspaper who reported from Berlin and had no connection to other news services appeared in the Times. ${ }^{130}$ Even though, they were not used often in the newspaper, however, it showed that the Times started to expand its coverage on Berlin and Germany. In fact, the New York Times had nearly double the number of front page articles from 1930 and 1931, which included new perspectives from the other journalists. ${ }^{131}$ The reason for changes cannot be fully contributed to one factor; however, it showed that Times recognized that Germany was becoming important enough to world events.

Both of the newspapers paid attention to the political tensions developing in Germany at the start of 1932. The only differences between the news coverage was how the correspondents reacted to the events, which can be attributed to their journalistic abilities and opinion. It is also important to note that 1932 was the time when foreign correspondents started to experience press regulation and censorship by the German government. Both Schultz and Enderis alluded to new rules in either their personal letters or articles. Schultz even mentioned that an entire department existed within the Foreign Office in order to watch over the foreign press in her letter to Robert McCormick on November 1932. ${ }^{132}$ The Nazis were not the ones that instituted such rules. Rather Germany was slowly descending into authoritarian rule even before 1933 . This is not to say that the foreign correspondents' situation did not worsen under the Nazis' rule in Germany. In fact,

\footnotetext{
${ }^{130}$ For examples of journalists see, Harold Callender, "The Nain Mind: A Study in Nationalism," New York Times, PHN, January 3, 1932, SM3; Hugh Jedell, “German Labor Held as Force for Peace,” New York Times, PHN, January 3, 1932, E3; R.C. Long, "Hindenburg's Vote Helpful to Market," New York Times, PHN, March 21, 1932, 28.

${ }^{131}$ This statistic was calculated by using the ProQuest database for the New York Times. The terms used in the search engine was Germany, Hitler, or Nazis. This showed that 49 front page articles were published between 1930 to 1931 and 78 articles in 1932.

132 Sigrid Schultz to McCormick November 23,1932; and Enderis, “Prussia Threatens Hitler's Expulsion.”
} 
the correspondents found themselves in a completely different situation by the time Nazis fully consolidated their power in 1934. By then, their journalistic freedoms had deteriorated and it had happened quickly.

The foreign correspondents in Germany did not immediately lose all of their rights as journalists when Hitler became chancellor in early 1933, because the Nazis did not have full control over the government. Over the next two years, the Nazis would increase the levels of political violence and intimidation in order to crush their political rivals' power. The most pointed example was how the Nazis used the Reichstag fire on February 27, 1933 to attack and demolish the Communists' and Social Democrats' power by blaming them for it. This fire allowed the Nazis to push through a questionable proposal written the day before that would limit civil liberties and stop future political protest. Therefore, the Nazis' mass arrests of communists were legally sound. ${ }^{133}$ This meant that the civil liberties and freedoms in Germany also disappeared for much of the German public, which changed the situation for foreign correspondents rather quickly from 1933 to 1934.

The correspondents experienced somewhat of a "transitional period," while the Nazis attempted to consolidate their power in the German government from 1933 to 1934. The Nazi press regulations largely remained hands off or indirect, which can be contributed to them wanting to avoid an international issue. In fact, the Nazis at first continued much of the same censorship and press regulations towards foreign correspondent as the Weimar Republic, but with a stricter resolve and force. Most of the correspondents' troubles revolved around trying to find a safe communication route to send their articles out of Germany. They also had to figure

\footnotetext{
${ }^{133}$ The Reichstag fire was started by Marius von der Lubbe. He was a Dutch communist that was attempting to work his way across central Europe in order to cross the border into the Soviet Union. He wanted to make a political statement by setting one of the governmental buildings on fire, which he planned without any help from the communist party. For more information, see Evans, Coming of the Third Reich, 321-333.
} 
out how to sort through the information provided to them by official governmental sources, such as the Propaganda Ministry, the Foreign Office, or the Nazi Party Press Chief. ${ }^{134}$ More importantly, they had to be weary of what news was being reported about the German government and the Nazi party in their respective newspapers, because it could incur negative repercussions from the German government. The correspondents had to decide in these years if they were willing to risk their journalistic careers and, in some cases even their life, in order to report accurate news from Germany.

Sigrid Schultz was one of the foreign correspondents who was willing to take a risk with her career in order to send her uncensored articles back home. It took courage and ingenuity to get around the Nazi press system. She never fully explained her drive and reasoning to report all of the news from Germany. Most likely, part of it can be attributed to her upbringing in Europe and experience in Germany during the first war, but nothing can be said for certain expect for one fact: Sigrid Schultz remained in Germany after 1933 and reported heavily on the Nazi government without showing much signs of censorship or wavering from her anti-Nazis stance.

At the start of 1933, Sigrid Schultz alluded to more censorship issues in her letters back home. A Chicago Tribune cable editor, George J. Scharschug, told Schultz in a letter on March 27,1933 not to worry about the censorship, because she was doing "an excellent job on the German situation." ${ }^{135}$ Schultz most likely sent him a letter or cable earlier in the month that discussed the troubles she was having with Nazi censorship and how it affected her reporting. Her message was written at the time when the Nazis started to consolidate their power in Germany. This might explain why Schultz had difficulties and worries with the Nazi censoring her articles, because civil liberties were basically being demolished in Germany. Most likely, the

\footnotetext{
${ }^{134}$ Marwell, "Unwonted Exile," 114.

${ }^{135}$ Mr. Scharschug to Sigrid Schultz March 27, 1933.
} 
German government was progressively limiting the press's freedom, because Schultz was not the only Chicago Tribune reporter to complain about German censorship.

Edmond Taylor, who was normally reporting from France, traveled around Germany for several of days in 1933 to provide some more mailer stories on the current revolution in Saar. ${ }^{136}$ Taylor wrote in a letter to Colonel McCormick on April 25, 1933 about how he could not get a detailed report on events past the German censors; however, Taylor did not describe how the Germans would censor his material. ${ }^{137}$ Taylor only came to Germany for news stories occasionally and, thus, did not have to worry about German censors completely ruining his career; however, in subsequent years, the French government would institute press regulations as well. ${ }^{138}$ Sigrid Schultz's career and reporting, on the other hand, depended heavily on finding a way around the German system.

Sigrid Schultz sent several letters and cables to Colonel McCormick and Mr. Scharschug that discussed how she worked in the Nazi press system. Most of these letters were dated from late December of 1933 and throughout 1934. This does not mean she made no attempt of working around the Nazi censorship prior to these letters. These documents are simply the earliest ones that mention how she changed her reporting in reaction to the Nazis' policies. Essentially, these letters allude to a structure that Schultz set up within Germany and its neighboring countries in order to send articles back home with the least amount of censorship

\footnotetext{
${ }^{136}$ The meaning of "mailer story" is unclear in the letter. Taylor was only correspondent to use the term in his letter from my research in the archives. This term does not seem to be a commonly used journalist today. "Mailer Story" may mean human interest story based on the context of the letter.

${ }^{137}$ Edmond Taylor to Colonel McCormick April 25, 1933, First Division Museum, Chicago Tribune Archive, XL 317 Kirkland \& Ellis Files II, Box 3, Folder 2.

${ }^{138}$ In another letter to McCormick on April 30, 1935, Taylor described how censorship was becoming a large deal in France. He had to deal with several court cases brought against him by the French government. Taylor alluded to McCormick asking him to write an article about his situation, but anonymously. This is discussed further in the next chapter. Edmond Taylor to Colonel McCormick April 30, 1935, First Division Museum, Chicago Tribune Archive, XL 317 Kirkland \& Ellis Files II, Box 3, Folder 3.
} 
and problems. This system changed throughout 1933 and 1934, because the Nazis tightened their control over the foreign press's freedom.

The first time she mentioned how she worked within the Nazi new press system was in her letter to McCormick on December 1, 1933. Her main focus in this letter was to describe the current state of journalism and politics in Germany through several different events. In the letter, she noted, "I just discovered a friend who will be leaving Germany in a few hours and I seize this opportunity to rush off a few uncensored notes to you!" ${ }^{139}$ She might even be referencing this very letter. She does not describe who the friend was or what was on the pages, but it showed that the Nazis were not taking material from people who were leaving Germany. She goes on to describe how German reporters would not risk talking to a foreigner let alone a foreign correspondent, because of the regime change. She also described how the previous German generation of newspapermen were forced out. She stated that, "[i]t is ridiculous to speak of the men running German newspapers nowadays as newspapermen. They are low ranking state officials." She even goes as far to describe them "file-clerks."140 Therefore, local news sources could not even be considered as news, but the official German government's point of view. The important question to ask did the foreign correspondents have the same reporting problem. Schultz's letter and articles do not confirm that any of her rights had been compromised, but it does show how the German government influenced her ability to report in an indirect way by limiting the available information.

This letter from December of 1933 also mentioned an incident about documents from the German Propaganda Ministry being published by Le Petit Parisien, a local French paper. The documents were two secret directives by Joseph Goebbels on how to shape the news about

\footnotetext{
${ }^{139}$ Sigrid Schultz to McCormick December 1, 1933, First Division Museum, Chicago Tribune Archive, I-62 Foreign Correspondents 1914-1955, Box 8, Folder 8.

${ }^{140}$ Sigrid Schultz to McCormick on December 1, 1933.
} 
France in a negative fashion. ${ }^{141}$ The incident itself is not important, but how the German government treated the revelation is relevant. Schultz described in the letter how the German newspapermen were commanded to pump foreign correspondents on any information about the event and then had to give up the names of foreign correspondents who talked too much about the details relating to Petit Parisien. ${ }^{142}$ Schultz did not clearly describe what happened to those correspondents or how the German reporters reacted to the command, but it showed how the Nazis attempted to watch the foreign correspondents without directly interacting with them.

Sigrid Schultz's reporting, however, showed no signs of slowing down from any censorship or sources issues. In an article, shortly after the Reichstag fire in February 1933, Schultz provided a detailed assessment of exactly what the presidential decree, Protection of People and State, did for the general German population's civil liberties. The decree virtually eliminated the civil liberties in Germany and extended the state of emergency. ${ }^{143}$ She stated that, "The decree virtually puts Germany under martial law with extraordinary powers placed in the hands of the police." 144 By using the words "martial law," Schultz was painting a picture of how the German government handled the social and political situation in Germany.

She enforced her opinion of the government by calling the decree a "reprisal" instead of a plan. Later on, Schultz used a quote by an unnamed spokesman, "In a few months the world will realize the great service Chancellor Hitler is rendering by stamping out communism. The parliamentary democratic regime is not coming back." ${ }^{145}$ This speaker was intent on supporting the Nazi regime; however, Schultz inclusion of it drove home the idea that Germany was not a

\footnotetext{
${ }^{141}$ Karen Fiss, Grand Illusion: The Third Reich, the Paris Exposition, and the Cultural Seduction of France (Chicago \&London: The University of Chicago Press, 2009), 14-15.

${ }^{142}$ Sigrid Schultz to McCormick on December 1, 1933.

${ }^{143}$ More precisely, the decree suspends the civil liberties, and allows police to arrest suspects for "protective custody." See Fisher, Nazi Germany, 626.

${ }^{144}$ Sigrid Schultz, "German Decree Annuls Liberty and Civil Rights: 'Martial Law' Set Up to Crush Reds," Chicago Tribune, PHN, March 1, 1933, 1.

${ }^{145}$ Schultz, "German Decree Annuls Liberty and Civil Rights."
} 
democracy anymore. This was reinforced by her description of how civil liberties were restricted for the Communists. Schultz could not have written it any clearer in this article, unless she spelled out that Hitler was a dictator and Germany was in trouble. Clearly, the editors of the Tribune supported her assessment, because this article appeared on the front page of the newspaper. More importantly, it also showed how confident Schultz was that she would not face any negative repercussions from the German government at this time.

In another article on April 8, 1933, Schultz continued to describe how Hitler took complete control over Germany and created a dictatorship. She stated, "While absolute control by Hitler and his allies over Germany is being enforced politically [,] a similar realignment is being effected in all walks of life with an enthusiasm and thoroughness that is breathtaking."146 She made an argument that no one was safe from the Hitler's political overhaul, which effectively made Germany a centralized state. This article failed to mention how the Jews were being phased out of the civil service at this time. She explained how, "the ministry of labor is drafting measures to eliminate Jewish physicians from insurance jobs and as medical examiners." ${ }^{147}$ Her use of "eliminate" does not leave any hope of them returning to their jobs. Most of Schultz's articles in 1933 were openly discussing Germany's social and political issues without positively slating them toward the Nazi government. ${ }^{148}$ Clearly, she found a way around German press regulation to send these articles with minimum amount of intervention in 1933. By the start of 1934, Schultz had more issues with reporting since she set up separate communication routes in Holland and Czechoslovakia in order to avoid German censors. She

\footnotetext{
${ }^{146}$ Sigrid Schultz, "Hitler Seizes Control of All German States: Dictatorship Extended by His Cabinet," Chicago Tribune, PHN, April 8, 1933, 3.

${ }^{147}$ Schultz, "Hitler Seizes Control of All German States."

${ }^{148}$ For examples, see Sigrid Schultz, "3 Killed, 312 Hurt in German New Year's 'War': Nazis and Reds Open '33 with Political Clashes," Chicago Tribune, PHN, January 2, 1933, 5; Sigrid Schultz, "Catholics Scrap German Parties; Nazis Supreme: Hitler in Sole Possession of Political Arena," Chicago Tribune, PHN, July 5, 1933, 7.
} 
first discussed these routes in a letter to Colonel McCormick on January 7, 1934. This letter discussed how she was happy to be also assigned to report on Holland and Czechoslovakia, because it gave her a chance to avoid the German censors and take in news from the outside world. ${ }^{149}$ This letter signaled the fact that correspondents had to leave Germany in order to perform their duties as correspondents and to receive the basic news from the world. It also showed that one of the most secure ways to get articles or papers out of Germany was to physical walk them across the border.

In a letter from March of 1934, Schultz also described how she was able to make a deal with Prager Presse in Prague for them to send her articles in exchange for copies of their news messages from London. ${ }^{150}$ This system of news exchange opened up another communication route for Schultz. It cannot be definitely said that other correspondents in Germany used the same communication routes, but the location made the most sense for anyone trying to avoid the prying eyes of the German censors. Prague is relatively close to Germany's borders and remained a strong democracy in 1934. Other cities like Paris would require a lengthy train ride, which would cost the newspaper a lot of money and time.

A couple of months later, there was a change in the tone of Schultz's letters to the Chicago Tribune. Her letter to Mr. Scharschug, the cable editor, on Aug 13, 1934 discussed how she was leaving Germany for a couple of days to "send out some treacherous mail or treasonable." 151 She also gave explicit directions not to have any of these articles to be published under her name, but did not provide any more information about her reasoning. Most journalists strive for their bylines and for space on the front page, because it gave them recognition for their

\footnotetext{
${ }^{149}$ Sigrid Schultz to McCormick January 29, 1934, WHC, Sigrid Schultz's Papers, Box 4, Folder 8.

${ }^{150}$ Sigrid Schultz to McCormick March 7, 1934 from Prague, First Division Museum, Chicago Tribune Archive, I62 Foreign Correspondents 1914-1955, Box 8, Folder 9.

${ }^{151}$ Sigrid Schultz to Mr. Scharschug August 13,1934, First Division Museum, Chicago Tribune Archive, I-62 Foreign Correspondents 1914-1955, Box 8, Folder 9.
} 
careers. If a story is missing its byline, it is almost impossible for anyone to track down the author. The only way would be to find the editor who placed the story for that edition; however, this was most likely the intent of Schultz. The Nazis would not have no legitimate way of connecting Schultz to her articles, which would protect her from any negative repercussions and allow her to continue her critical reporting.

Schultz's change in demeanor could also be contributed to an incident with the Chicago Tribune's Paris edition. Schultz briefly mentioned in the letter to the editor, George Scharschug, about how the German government reacted to a critical article of hers that had been published in Paris. She explicitly asked the editors in Paris to soften it, because of the effect it could have on her position in Germany. She wrote, "it would have gotten by if had been toned down a bit. Threats have been sizzling in the air ever since. ${ }^{1152}$ Schultz had to take steps in Germany to start protecting her identity on the more negative articles by 1934 , which at times required more than changing her name. Case in point, Schultz discussed how the telephoning stories through Paris remained unsafe, because of mistakes made by the colleagues in Paris. She wrote one of her articles contained "[c]omradly assassination" instead of "cowardly assassination." 153 These terms did not necessarily cause issues for this particular story, but Schultz pointed out that it could ruin her position in Germany in the future. Ultimately, Schultz's complaints about the telephone operators in Paris and issues over the attribution of articles to her showed how one infraction against the Germany government could cause a foreign correspondent to lose her position or, even worse, to be arrested.

Sigrid Schultz was not the only correspondent who had to learn how to operate in this precarious position in Germany. The New York Times journalists had to interact with German

\footnotetext{
${ }^{152}$ Sigrid Schultz letter to Mr. Scharschug August 13,1934.

${ }^{153}$ Sigrid Schultz letter to Mr. Scharschug August 13,1934.
} 
government very carefully, because the owner of the paper was Jewish. The Jewish heritage of the New York Times owner played a progressively larger factor in their correspondents' position in Germany, because the German government already had negative opinion of the Jewish owned newspaper. Therefore, any New York Times correspondent had to be aware of how his reporting would affect the newspaper's fragile relationship with the German government. ${ }^{154}$ The correspondents were clearly conscious of their situation, because Frederick Birchall wrote to Mr. Sulzberger on March 21, 1933 about how Times was pretty much doomed in Germany. ${ }^{155}$

Laurel Leff states that the New York Times Berlin News Bureau protected this fragile relationship with Germany and its reputation by hiring Otto Tolischus. Leff argues that Tolischus and Birchall's investigative reporting would balance Enderis's sympathies for Germany; however, she ignored Enderis's previous experience with the German government during World War I. ${ }^{156}$ In fact, The New York Times editor Edwin L. James described in a memorandum from 1940 how Enderis had remained in Germany for the last 30 years with short breaks for vacation and had some experience working under wartime conditions. It is unclear what exactly Enderis did immediately after the Nazis consolidated power in 1933 in order to help the Times remain open. The memorandum from 1940 was one of the first times Enderis's role was acknowledged in keeping the bureau open after 1933. James described that Enderis had become more of a negotiator with the government. ${ }^{157}$ The aspects of this relationship do not come to light until the New York Times correspondents got into trouble with the government after 1934; however, this

\footnotetext{
${ }^{154}$ Leff, Buried in the New York Times, 52-53.

${ }^{155}$ Frederick Birchall to Mr. Sulzberger March 21, 1933, New York Public Library, New York Times: Arthur Hays Sulzberger Papers, Box 6, Folder 26.

${ }^{156}$ Leff, Buried in the New York Times, 55-56.

${ }^{157}$ Memorandum on Mr. Enderis by Edwin L. James October 23, 1940, New York Public Library, New York Times: Arthur Hays Sulzberger Papers, Box 112, Folder 7.
} 
does not mean that Enderis did not play the negotiation role during the Nazis' rise and consolidation of power, as well.

Leff's characterization of The Times's Berlin News Bureau does have some merit and logic. It would have been a logical choice for the New York Times to hire Tolischus in reaction to the Nazis' rise in power. Based on the date of the memorandum, The Times most likely was completely unaware of Enderis's emerging role as negotiator. Tolischus also had a solid cultural background in Germany, because of his family connections and since he had lived there until he was 17 years old, when he immigrated with his parents to the United States. He graduated from Columbia School of Journalism by 1916, and afterwards served in the United States Army during World War I. He remained in Europe as a freelance journalist throughout the 1920s until he was hired by the Times in 1933 to work in Berlin. ${ }^{158}$

Much of Tolischus's reporting in 1933 and 1934 is comparable to that of Schultz, because of its detailed and critical attitude towards the Nazis. On July 15, 1933, he reported how Hitler was seizing all of his enemies' property in order to solidify his power over Germany. He showed his opinion of Hitler's actions by comparing him to the communists. Most likely, Tolischus purposely did this to insult the Nazi party, because at the time they were having mass arrest of communists in reaction to the Reichstag Fire. He also does not whitewash any of the effects on the people in Germany, "the government also undertook to silence all German critics in foreign lands by applying the policy of seizing their relatives." ${ }^{\prime 159}$ This article is clearly showing how the Nazi regime took away the civil liberties of people and lumping them together

\footnotetext{
${ }^{158}$ Leff, Buried in the New York Times, 55-56.

${ }^{159}$ Otto D. Tolischus, "Hitler Will Seize Property of Foes," New York Times, PHN, July 15, $1933,1$.
} 
with their political enemy, the communists. His reporting does not veer away from this type of critical nature. ${ }^{160}$

In another article on November 5, 1933, Tolischus discussed the trial of the people who set the Reichstag on fire, which was essentially the trial of Dimtroff. He was the alleged mastermind beyond the Reichstag fire in early $1933 .{ }^{161}$ Tolischus titled it, "Goering and A Red Exchange Taunts in Reich Fire Case," with a subtitle of "Battle of Invective Terminates." $162 \mathrm{He}$ did not outright discuss his opinion of the court case, however, an idea of it comes through simply by his titles. His use of red in the title directly relates to the Nazis and Communists yet again. Tolischus also belittles the entire event by saying everyone involved was a termite. Like Schultz, his critical reporting does not let up on the Nazis' actions from 1933 to 1934.

These articles or News Bureau's hearsay cannot provide any decisive indication of how and why the New York Times decided to react towards the Nazis rise in power at the start of 1933. It cannot be argued that the New York Times remained open after 1933. From 1933 to 1934, all of the reporters had equal representation of their work on the front page. This does not necessarily mean that all reporters were seen has equals by The Times. It does show however that The Times had not made a clear choice to silent or completely ignore one of the reporters. More importantly, the combination of reporters assigned to the Berlin News Bureau kept the Times from shutting down in 1933.

\footnotetext{
${ }^{160}$ For examples of his critical articles see Otto D. Tolishus, "400,000 Germans to be Sterilized," New York Times, PHN, December 21, 1933, 1; Otto D. Tolishchus, "Reich is Pressing War on Liberties," New York Times, PHN, December 31, 1933, E1.

${ }^{161}$ The trial was held in Germany from September 21 to December 23, 1933. The German Communist leader Ernst Torgler and three Bulgarian Communists, Georgi Dimitroff, Wassil Taneff, and Blagoi Popoff were put on trial with Marinus van der Lubbee. They were not convicted or executed like Marinus van der Lubbee. For more information see Fisher, Nazi Germany, 271-272.

${ }_{162}$ Otto D. Tolischus, "Goering and A Red Exchange Taunts in Reich Fire Case," New York Times, PHN, November $5,1933,1$.
} 
The foreign correspondents experienced different levels of press regulation from the German government between 1930 and 1934. Initially, the foreign press was able to report almost anything about events in Germany. They did not face the same regulations as the German press, which already had part of their freedom curtailed at the start of 1930. Foreign correspondents began to have issues with reporting in 1931, which was the same time that Hitler gained in political strength. The standing German government attempted to curb Hitler's popularity through the press, which included curtailing foreign and domestic press. This is an important case study of how a government's well intentioned idea to start centralizing its control can set a bad precedent for later governments.

The foreign correspondents' situation did not change again until Hitler and the Nazi Party began to consolidate their power after 1933. At first, the German government restricted the foreign press in an indirect way by limiting the available information. This method was intended to avoid any international incidents due to the treatment of a foreign correspondent. This brief period of hand-off regulation did not last long with the German government, because of the Nazis' concerns over their media image. Over the course of a year, this progressed into a complicated German press system focused on keeping track of foreign correspondents' articles about the German government.

The foreign correspondents who survived in the German press system were the ones who recognized how their situation was changing day by day. Sigrid Schultz had a deep understanding of how European and, especially, German culture operated, which gave her the necessary tools to sense the political changes. Schultz's articles were constantly drawing out the German social and political issues from 1930 to 1934. More importantly, she also reacted to the events by starting to develop new methods of reporting. This is not to say that the other 
correspondents assigned to in Germany were unable to write on the unfolding political chaos. The New York Times journalists produced similar articles to that of Sigrid Schultz. Unfortunately, the foreign correspondents' situation only gets progressively worse from the end of 1934 as Europe's overall political situation becomes more tense. 


\title{
CHAPTER III
}

\section{THE NAZIS’ TIGHTENING CONTROL OVER JOURNALISTS’ TYPEWRITERS FROM}

\author{
1934 TO 1939
}

"I am proclaiming most loudly that I know nothing of the story because I believe we are on the eve of very interesting developments of vital importance for the future of Europe. I would prefer not to make it too easy for Nazi friends to oust the Tribune Correspondent... , 163 -Sigrid Schultz (Chicago Tribune Correspondent) on October $3^{\text {rd }}, 1936$

At the start of 1934, foreign correspondents in Germany found themselves in a situation where their reporting and safety were directly connected. Sigrid Schultz wrote a report that described how a Czechoslovakian correspondent, Ludwig Popper, was arrested secretly by the Stormtroopers (SA) and taken to their prison, "Columbia House," describing this place as "one of the best known beating up quarters in town." ${ }^{164}$ According to her, he seemed to be fine, but he pushed for the Foreign Press Club to gain a promise from the German government that no correspondent be imprisoned at the Columbia House. Schultz stated that the club could not even set up a meeting with Reich Marshal Hermann Goering. Later on in the report, she wrote, however, "if one is a little careful, I'm sure there is no need to be nervous." ${ }^{165}$ Schultz had confidence in the security of her position in Germany, but most correspondents did not. The possibility of being arrested, expelled from Germany or, even worse, sent to Columbia House

\footnotetext{
${ }^{163}$ Sigrid Schultz to Robert McCormick October 3, 1936, First Division Museum, Chicago Tribune Archive, I-62 Foreign Correspondents 1914-1955, Box 8, Folder 9.

${ }^{164}$ Confidential Report, First Division Museum, Chicago Tribune Archive, I-62 Foreign Correspondents 1914-1955, Box 8, Folder 6. This report was unsigned and undated by Sigrid Schultz. The only marking on the document is "confidential." Most likely, this report was written by Schultz in early 1934, because it mentioned Paul von Hindenburg was near death. He died in August of 1934, which means the report had to be written before August. The Columbia House was used as a Gestapo prison in Berlin, which was taken over by the Inspektion der Konzentrationslager (IKL) or Inspectorate of Concentration Camps in December 1934. The IKL was led by Theodor Eicke and in charge of organization and administration of the concentration camps. Hundreds of Jews, Social Democrats, and Communists were taken to this prison and tortured before being sent to concentration camps. It closed down in 1936, because it did not have enough space for all prisoners. See Klaus P. Fisher, Nazi Germany: A New History (New York: Continuum, 1998), 274 and Nikolaus Wachsmann, Kl: A History of the Nazi Concentration Camps (New York: Farrarr, Straus and Giroux, 2015), 86, 97.

${ }^{165}$ Confidential Report, First Division Museum, Chicago Tribune Archive, I-62 Foreign Correspondents 1914-1955, Box 8, Folder 6.
} 
would have caused concern. This left the correspondents with the choice of appeasing the Nazis by publishing positive stories about them or taking a risk with critical reporting.

Foreign correspondents were not the only ones who had to face this question about the Nazi party. Western nations had to evaluate the Nazi party and decide how to work with them by 1934, because the Nazis had consolidated its power in Germany. The Nazis had the political power to transform Germany's political structure from a multi-party state into a one party system. They were able to gain power by using strategies such as inciting violence in the streets, secret imprisonments, and murder to stop political enemies. Richard Evans argues that Hitler intended to create an atmosphere of fear and chaos in the Germany, while promoting Nazis' ideals with a constant stream of propaganda. This created a new German culture based only on Nazi values, which would then foster little opposition from the German population. ${ }^{166}$

The Nazis' known actions were seen as justifiable by the public, because the German press painted the Nazis' political enemies as threats. ${ }^{167}$ This provided the Nazis with the legitimacy to address their political enemies with acts of violence. A well-known example is how Nazis used the Reichstag fire on February $27^{\text {th }}, 1933$ to round up and crush the communists in Germany. Hitler argued that it was the start of a communists' revolution and scared most of the German governmental officials into passing laws similar to that of martial law. ${ }^{168}$ The Nazis' last political restraint was lifted when President Hindenburg died in August of 1934. This allowed Hitler to consolidate the office of the chancellor and presidency, thus, making him the head of state and the most powerful German political leader. ${ }^{169}$ This paved the path for Hitler to test the boundaries of the Versailles Treaty by doing such things as introducing openly rearmament

\footnotetext{
${ }^{166}$ Richard J. Evans, The Third Reich in Power 1933-1939 (New York: The Penguin Press, 2005), 38-40, 118.

${ }^{167}$ Evans, The Third Reich in Power 1933-1939, 38.

${ }^{168}$ Evans, The Third Reich in Power 1933-1939, 67-68.

${ }^{169}$ Evans, The Third Reich in Power 1933-1939, 42-45.
} 
programs in 1935; remilitarizing the Rhineland in 1936; the Anschluss of Austria in 1938; and the take-over of Czechoslovak Sudeten territories after the Munich conference in September $1938 .^{170}$

In 1934, foreign correspondents across Europe became an important gateway of information for the American public about how the German and European political situation shifted because of the Nazis. ${ }^{171}$ Correspondents in Germany were not the sole source about Europe's politics, because other European countries grew concerned about Hitler and the Nazis as well. These reporters' articles were a window into whether or not Europe's political would descend into another war. However, reporters outside of Germany were not always free of censorship and governmental influence either. The correspondents' ability to report on the Europe's situation depended completely on how their host country reacted to the political situation, and the individual correspondents' capability to work with their respective governments.

By 1935, other European countries became concerned about how released information to the media could affect their political position on the international stage and, thus, the safety of their country. Nevertheless, the Germans were at the forefront of limiting the press's freedom to report on events after 1934. The Nazis made it difficult for any reporter to write critical articles about Germany by limiting the available information. There was only a brief moment of relief from direct German censorship in 1936, because it hosted the Olympics. Essentially, the Germans wanted the flood of visiting foreigners to leave with a good impression of Nazi Germany. Therefore, correspondents in Germany and its surrounding European countries came under new governmental press rules, which partially defined what information was provided to

\footnotetext{
${ }^{170}$ Fisher, Nazi Germany, 396-402, 408-409, 414-431.

${ }^{171}$ Selig Alder, The Isolationists Impulse: Its Twentieth-Century Reaction (New York: The Free Press, 1957$), 117$.
} 
the American public. However, the most defining factor was how willing a correspondent was at pushing the boundaries of the governments' press rules and risking their careers and in some cases their lives.

This chapter explores how the German press system and rules changed after the Nazis' consolidation of power in 1934 up to 1936 . The different aspects of the press situation are highlighted by examining Chicago Tribune Berlin correspondent, Sigrid Schultz, and then all of the New York Times Berlin correspondents. The next section discusses how correspondents in England, France, and the Soviet Union were affected by new governmental press rules. The final section examines how the German press rules became even tighter from 1936 to the start of the war.

Reporting from Germany was seen as one of the most difficult assignments for any foreign correspondents in 1933. Leff argues that the German government kept a tight watch over any information made available to the press. This made it difficult for any reporters to find reliable sources and to send their news reports through the wireless. ${ }^{172}$ This was not a new situation to the correspondents in Germany, because the Weimar government started to centralize the state's control over the press as a way to maintain its control. ${ }^{173}$ The Germans further developed these controls to impose their will on domestic and foreign press while Hitler consolidated his power from 1933 to 1934 . Once the Nazis had control over the German government, the correspondents had to learn how to function in an authoritarian state which had little tolerance for public opposition.

The important question to ask is how the correspondents responded to the German press system after 1934. What factors would lead to correspondents taking a risk with their careers and

\footnotetext{
${ }^{172}$ Leff, Buried by The Times, 50-52.

${ }^{173}$ Bernhand Fulda, Press and Politics in the Weimar Republic (Oxford: Oxford University Press, 2009), 200-203, 222-224.
} 
in some cases their lives to report the truth? A simple answer does not exist for these questions, because of the correspondents' complex situation. The correspondents' reports were heavily shaped by their ability to work in the German press system. It was fairly complicated, because of the multiple state and party organizations involved and changes made to the Nazi press leadership in 1937. The correspondents had to work in this multi-organizational, complex system of censorship to continue their stay in Germany. Ultimately, the reporters had to find the middle ground among the German news system and the requests by their respective newspapers. This system cannot be found in any Nazis governmental handbook, but can be gleamed from how the correspondents described their encounters with the government over their articles.

In simple terms, the system was fully established after the Nazis consolidated their power between 1933 and 1934. One section of the press system was led by Section IV of the Propaganda Ministry and responsible for non-party press in Germany. Walter Funk led this section of the Propaganda Ministry until 1937; thereafter, the press chief of the Nazi party, Otto Dietrich, took over. Most likely, the foreign correspondents dealt with Wilfred Bade, because he was the head of the Foreign Press Section of Section IV. ${ }^{174}$ Unfortunately, it remains unclear how Funk and Bade worked with the American foreign correspondents at the start of the Nazis regime.

By 1937, Bade was replaced by Karl Bömer who led the department until 1941. Historian Bramsted describes Bömer as well liked by the correspondents, because of his liberal press rules, such as talking to them about Hitler's girlfriend Eva Braun in order to give them a "human interest story." Bramsted contributes this to Bömer's extensive travel in the United States and

\footnotetext{
${ }^{174}$ David George Marwell, "Unwonted Exile: A biography of Ernst “Putzi” Hanfstaengl," (PhD diss, State University of New York, 1988), 113-115. There was not a clear reason why Walter Funk left his position or why Otto Dietrich was chosen as his replacement. This change does correspond with a foreign press liaison, Ernst Hanfststaengl, leaving his position in 1937.
} 
other experiences with foreign press around the world. Essentially, Bömer understood how correspondents operated in foreign countries and how to develop a working relationship with them. $^{175}$

There was also a press section in the Foreign Ministry, which shared the responsibility of taking care of any foreign press matters with the Propaganda Ministry. This press section was the mirror image of the Propaganda Ministry's section in terms of having an expert assigned to each country's press. It remains unclear who headed their foreign press division, but its envoy for press conferences was Paul Schmidt. This most likely meant he was head of the press division in the Foreign Ministry under Joachim von Ribbentrop. The reporters commonly described him as "charming, but mostly ruthless and arrogant and in addition a poor linguist," which made his press conferences were unpopular. ${ }^{176}$ It remains unclear from the correspondents' writings how the Foreign Ministry press section interacted with the Propaganda Ministry. One can be certain that German government made it difficult for foreign correspondents to gather information.

This German press system provided the foreign correspondents and domestic press with a couple of options to collect daily information about German policy and to ask questions.

Historians Derrick Sington and Arthur Weidenfeld state that the Propaganda Ministry and Foreign Office provided three daily briefings for the press; however, these were only useful if one spoke German. American correspondents also found the ministries presented little

\footnotetext{
${ }^{175}$ Karl Bömer was fired in 1941, because he drunkenly spilled information about the possible top secret invasion of the Soviet Union at a Bulgarian legation in the spring of 1941. He was given a prison sentence after Joseph Goebbels stepped in with evidence to save him from the death penalty. Dr. Ernst Brauweiler took over his position after 1941. See Ernst K. Bramsted, Goebbels and National Socialist Propaganda 1925-1945 (United States of America: Michigan State University Press, 1965), 115-16.

${ }^{176}$ Bramsted, Goebbels and National Socialist Propaganda 1925-1945, 116 and Ronald Smelser, "The Holocaust in the Popular Culture: Master-Narrative and Counter- Narratives in the Gray Zone," in Gray Zones: Ambiguity and Compromise in the Holocaust and its Aftermath, ed. Jonathan Petropoulos and John K. Roth (New York: Berghahn Books, 2005), 276.
} 
information that could be useful for their newspapers. ${ }^{177} \mathrm{~A}$ reason for the lack of information at these conferences was not given. It also remains unclear if any of the correspondents from the Chicago Tribune or New York Times attended all of these press briefings. Probably, someone from the news bureau attended them in order to gather the information from the German government.

There also existed the position of the Reichpressechef who was the press liaison for the “party organs." ${ }^{178}$ Otto Dietrich held this position from 1931 to 1940 ; however, the foreign correspondents most likely did not interact with him. Ernst Hanfststaengl lead the Foreign Press section under the Reichpressechef, which meant he "was responsible for representing the Nazis party to the foreign press." ${ }^{179}$ The relationship he had with the foreign press remains unclear based on the correspondents' writing and articles. A definitive conclusion about their lack of writing cannot be made; however, most likely the correspondents had little interaction with him. If they had extensive meetings with him, it would have appeared in their writings or articles. Overall, the German press structure reinforces the idea that Germany was a dual state when the Nazis took control over the government. This meant that both the state and party organizations remain intact in order to govern Germany; however, both organizations were still based on Nazi ideology. ${ }^{180}$

Clearly, the German press structure was designed to be complex and difficult to navigate. This system allowed the state to control information being made available to the domestic and foreign press, but also had experts keeping track of what was being written about Germany and the Nazis. Thus, it was another indirect way to protect the Nazis' media image in the foreign

\footnotetext{
${ }^{177}$ Derrick Sington and Arthur Weidenfeld, The Goebbels Experiment: A Study of the Nazi Propaganda Machine (New Haven and Yale University, 1943), 101-102.

${ }^{178}$ Marwell, "Unwonted Exile," 114.

${ }^{179}$ Marwell, "Unwonted Exile," 114

${ }^{180}$ Fischer, Nazi Germany, 310-311.
} 
press without directly taking action against the foreign correspondents. Unknowingly, the many press divisions were also a source of opportunity for the correspondents, because it was difficult for them to coordinate and work together. Essentially, the German's large and complex press system was a collective of press divisions without one leader to direct everything. It can be argued that the press division simply could not work together, because of their rivalry to attract more correspondents to their press conferences. ${ }^{181}$ The correspondents would need to have a full understanding of these organizations and departments in order to work around their press rules. This knowledge would have allowed them to find the loopholes in the system in order to manipulate it for their own means. More importantly, they needed to be aware of how the German press divisions collected information on them and their writing, because it could easily result in being expulsion from Germany

The Chicago Tribune's Berlin correspondent, Sigrid Schultz, continues to be the best example for how a correspondent operated in the German press system. She had multiple encounters with the Nazis over her critical reporting as early as 1934 and remained in Germany throughout the 1930s. From August of 1934 to 1939, she published about 1,000 news stories with 251 as front page articles about Germany. ${ }^{182}$ The increase in her front page articles is most likely related to the Nazis' rise in power, but it cannot be fully explained through the political change. Probably, the political situation in Germany became more important for the United States; thus, the Chicago Tribune reported more news on its development.

\footnotetext{
${ }^{181}$ The press divisions competed with each other to have their press conferences mentioned the most by reporters' articles. This was seen as a mark of honor or status for the press divisions. They also had a rivalry over the best press club. In fact, Goebbels took seven million dollars to remodel his club, Auslands Club, in 1940. For more information, see Bramsted, Goebbels and National Socialist Propaganda 1925-1945, 116-117; and Sington and Weidenfeld, The Goebbels Experiment, 101.

${ }^{182}$ These numbers were taken from ProQuest Historical Newspapers database. The terms used were Sigrid Schultz as author and Germany as subject term.
} 
Schultz's volume of reporting meant she found a way to operate in the Nazis press system without giving them a reason to expel her. One should remember that Schultz was fluent in German and had an extensive network of contacts. This allowed her to develop relationships with important officials, such as United States Ambassador William Dodd and Reich Marshal Hermann Göring. Schultz rarely discussed in letters or articles on how her network informed her reporting, but it is clear how it helped her to avoid some conflicts with the German government. ${ }^{183}$ The Germans commonly used the threat of expulsion to silent any highly critical journalists. They also used written warnings; denial of telephone rights; suggestions to leave; expulsion for a couple of days; and threats of being charged for high treason. ${ }^{184}$ These punishments aimed to create an atmosphere of fear and obedience among the foreign journalists, but these punishments were highly dependent on the journalist's nationality and gender.

Schultz had layer of protection from the Germans' wrath, because she was an American and a woman. If the Nazis caused any harm to an American citizen, it would cause an international incident between the two countries. ${ }^{185}$ In fact early on, the Nazis attempted to gain the approval of American correspondents by doing them favors, such as giving them extra rations. ${ }^{186}$ The aim was to influence the American correspondents into writing positive stories about the Nazis and Germany for the American public. Schultz was also protected as a woman, because of Nazis' gender norms. Typically, the Nazis persecuted the men, while leaving the

\footnotetext{
${ }^{183}$ For information about her fluency in several different languages see Chapter One page 21. Most likely, Schultz had a friendly relationship with William Dodd. They exchanged a couple of letters between them and she appeared in his published diary. For an example of an exchanged letter see William Dodd to Sigrid Schultz July 17, 1934, Wisconsin Historical Center (WHC), Sigrid Schultz's Papers, Box 11, Folder 3; Dear Little lady from unknown author February 28, 1935, WHC, Sigrid Schultz's Papers, Box 11, Folder 3; and William E. Dodd, Jr and Martha Dodd, ed., Ambassador Dodd's Diary (New York: Harcourt, Brace and Company, 1941), 59,115, 170, 198. It is more difficult to define the relationship between Schultz and Göering, because of her hatred for Nazis. She notes a couple of times about how she had dinner with him. She does not provide any more information about the type of relationship they had. See Meet Your Neighbor, WHC, Sigrid Schultz's Papers, Box 2, Folder 4.

${ }^{184}$ Bramsted, Goebbels and National Socialist Propaganda 1925-1945, 122.

${ }^{185}$ Evans, The Third Reich in Power 1933-1939, 337-342.

${ }^{186}$ Bramsted, Goebbels and National Socialist Propaganda 1925-1945, 118-119.
} 
women largely alone to handle the aftermath and fend for herself. ${ }^{187}$ Schultz learned how far she could push these layers of protection in her reporting, while also developing other ways around the Nazis' rules.

By 1934, Sigrid Schultz recognized the need for new approaches to survive in Nazi Germany as a reporter. Schultz purposely set-up a communication outlet in Prague by the start of 1934 to get around some of the censorship. She chose to go through Prague, because CzechoSlovakia was a stable democratic country which made no attempt to censor her work and it was fairly close to Germany. This allowed her for a brief period of time to send detailed reports about Hitler and the Nazi Party from Prague. ${ }^{188}$ Schultz also realized quickly that she needed to increase further her security and to diversify her reporting methods to keep her articles wellinformed and remain off of the German radar.

Schultz's realization can be seen in her confidential letter written on July 20, 1935 to another foreign correspondent, George Seldes, in which she described how other reporters functioned in Germany and their situation. ${ }^{189}$ Seldes left the Chicago Tribune in 1928 to become a freelance reporter and writer so his location remains unclear, because he had no professional ties to any large newspaper. This letter was labeled as confidential and sent from CzechoSlovakia in an attempt to avoid the Nazis' prying eyes. This meant Schultz most likely discussed freely the events in Germany, because the letter would probably not be read by the German government. In fact, she seemed more worried that all of her previous letters to him from the last winter only just arrived. Seldes also seemed to have been a friend of Schultz, because he was a

\footnotetext{
${ }^{187}$ Marion A. Kaplan, Between Dignity and Despair: Jewish Life in Nazi Germany (New York and Oxford: Oxford University Press, 1998), 5-10.

${ }^{188}$ See Chapter One page 50-51 for a detailed analysis of the communication route through Prague.

${ }^{189}$ Letter to George Seldes July 20, 1935, Wisconsin Historical Center (WHC), Sigrid Schultz's Papers, Box 4, Folder 4. Only the first two pages of this letter was found in this archive. Therefore, it was not signed by Sigrid Schultz, but addressed to George Seldes. Most likely, she wrote this letter to him, because she was one of the few correspondents who sent letters from Czechoslovakia in order to avoid censorship.
} 
former Chicago Tribune's foreign correspondent and due to her friendly demeanor toward him throughout the letter. She mentioned such things as reading his book and gave him some friendly professional advice about what he should write for his next article. ${ }^{190}$ Therefore, Schultz would not be afraid of being highly critical or to provide an accurate picture of the current reporting situation in Germany in this letter from 1935. She probably had the aim of gathering advice from a fellow veteran reporter on how to approach her situation.

Schultz described how the Nazis were able to shape some of the other correspondents' reporting through bribery and intimidation. Schultz's basic observation was that the ordinary reporters could easily be influenced by the Nazi press system, even if they had the intention to report accurate news. An example of a subtle form of influence by the Nazis was providing Reichmarks to new reporters. The local currency was difficult for veteran journalists to find since their salaries were typically paid in dollars. Schultz contributed this to the Nazis trying to establish some rapport with the foreign reporters. ${ }^{191}$

Schultz also explained her theory that some of the American news services were being paid by the Nazis to send back their approved news stories. Her evidence for the accusation was her previous negotiations with the German news services during the Weimar Republic. She attempted to set up an exchange of news stories with local German news services; however, it fell apart when the Germans demanded her to send "messages which they deemed of vital

\footnotetext{
${ }^{190}$ George Seldes was a famous foreign correspondent who protested the suppression of news and businesses' influence over newspapers. After he left the Chicago Tribune in 1928, he wrote several books about how governments attempted to censor the news. He campaigned for reporters to have a set of ethical guidelines, which did not become standard until after World War II. For more information, see William Dicke, "George Seldes is Dead at 104; An early, Fervent Press Critic," The New York Times (NYT), July 3, 1995, http://www.nytimes.com/1995/07 /03/obituaries/george-seldes-is-dead-at-104-an-early-fervent-press-critic.html.

${ }^{191}$ Letter to George Seldes July 20, 1935.
} 
importance" to the United States. ${ }^{192}$ She stated that the agreement with the government has some benefits, but it does come with the price of Nazi intimidation.

Schultz speculated that at least William Randolph Hearst's newspapers and United Press service (U.P.) had a news exchange with the Nazi government. This required the American news companies to follow Nazis' press requests in order to remain in Germany and their favor.

Schultz's evidence of the Nazis' influence was how each organization refused to hire Jews in Germany, because it would not meet with the approval of the Nazis. She also argued that the United Press would slip a sentence of Nazi propaganda into their reports. Her evidence was from her conversations with U.P. customers in Hungary, Switzerland, and Czechoslovakia. ${ }^{193}$ This was only her observation about news services in Berlin and she even stated in reference to Hearst's contract with the German government that "not seeing the Hearst Papers I do not know how it works out." ${ }^{, 194}$ Her observations in this letter support her theory about the two newspaper services having a relationship with the Nazis, but they cannot be proven based solely on her word. The important aspect to consider about Schultz's letter is that it speaks to the developing press situation in Germany, because it describes the type of pressures faced by the correspondents.

More research needs to be done in order to establish this extreme of a case against any press service residing in Germany during the 1930s. It was only recently that historian Harriet Scharnberg made a connection between the Associated Press (A.P.) and the Nazis. She was able to use sources in Germany in order to describe the news exchange agreement between them. Essentially, the A.P. made an agreement with the Nazis to give them their news stories and

\footnotetext{
${ }^{192}$ Letter to George Seldes July 20, 1935.

${ }^{193}$ Letter to George Seldes July 20, 1935.

${ }^{194}$ Letter to George Seldes July 20, 1935.
} 
photos in order to remain in Berlin. ${ }^{195}$ This does not mean that the Hearst's newspapers or the United Press services had the same agreement as the A.P-as Schultz charges-, but it shows that the Nazis were at least approaching these news services and their reporters with some sort of offer in order to influence what was written by the foreign correspondents.

Schultz's negative attitude towards this type of reporting indicates that she most likely avoided making any such agreements with the Nazis for the Chicago Tribune. She even stated that "the agencies which want to sell services in dictator infested countries [were] the really obedient people." ${ }^{196}$ Schultz was avoided needing such an agreement with the Nazis and survived in Germany as a reporter. This was a testament to her abilities as a journalist, because her writing remained unchanged while the Nazis tighten a noose around the press's freedom.

A blunt example of her critical nature is her article published on August 26, 1934, which was about Dorothy Thompson being asked to leave Germany in 1934 due to one paragraph in her interview with Hitler from 1931. Schultz's article outright questioned Hitler's press policy and actions by pointing out their inconsistencies through Thompson's experience. Essentially, the German officials were able to argued based on the passage that Thompson wanted to hurt Germany's reputation. A press law had been passed in 1932 that any person could be expelled if their intent was to harm Germany’s reputation can be proven. In the article, Schultz described Thompson's view on her being asked to leave Germany by using multiple statements from Thompson. She quoted Thompson as saying, "I cannot forget that people were sent to concentration camps for saying about certain Strom Troop leaders the same things which Hitler

\footnotetext{
${ }^{195}$ Harriet Scharnberg, "Das A und P Der Propaganda: Associated Press und die nationalsozialistishch Bildpublizistik," Studies in Contemporary History (2016), accessed April 3, 2016, http://www.zeithistorishcheforschungen.de/1-2016/id\%3D5324.

${ }^{196}$ Letter to George Seldes July 20, 1935.
} 
had later to say to the whole world in the [Reichstag]." ${ }^{\text {,197 }}$ Thompson was referring to the Night of Long Knives, which was when Hitler ordered the murder of the Stormtroopers' leaders to minimize them as a political threat to his power. ${ }^{198}$ The act of Schultz reprinting Thompson's statements on her front page article for the Tribune showed her unwavering support from Thompson's point of view.

Schultz reinforced Thompson's conclusion by stating, "her departure was ordered despite the fact that the foreign office and the secret police were fully aware of the impression it was bound to create" for the world. ${ }^{199}$ She discussed how French and Soviet correspondents were expelled from Germany, but their respective governments also retaliated by expelling German correspondents from their countries. ${ }^{200}$ Clearly, Schultz was not afraid to question the Nazis' policies or actions despite the fact that their power was only growing in Germany. Her criticisms of the regime did not soften either, but only became more critical in the next years. More importantly, the Chicago Tribune editors did not silent her criticisms by placing her articles on the front page. Many of them had fiery titles, such as the article on January 3, 1936, "Hitler Warns League to Mind Own Business" or the one on July 20, 1935, "Nazis Open New Drive to 'Purge' Berlin of Jews.', 201

The Chicago Tribune editors would not have showcased Schultz's articles if they did not have trust in her abilities as a journalist. Sigrid Schultz was one of the most well-informed American foreign correspondents, which allowed her to write critical articles at a time when the German censored and blocked others. A case in point was Schultz's extensive knowledge about

\footnotetext{
${ }^{197}$ Sigrid Schultz, “Sinclair Lewis' Wife Banished from Germany: Expulsion Based on Hitler Interview,” Chicago Tribune, ProQuest Historical Newspaper (PHN), August 26, 1934, 1.

${ }^{198}$ Evans, The Third Reich in Power 1933-1939, 20-41.

199 Schultz, "Sinclair Lewis' Wife Banished from Germany."

${ }^{200}$ Schultz, "Sinclair Lewis' Wife Banished from Germany."

${ }^{201}$ Sigrid Schultz, "Hitler Warns League to Mind Own Business," Chicago Tribune, PHN, January 3, 1936,1 and Sigrid Schultz, "Nazis Open New Drive to 'Purge' Berlin of Jews," Chicago Tribune, PHN, July 20, $1935,1$.
} 
Hitler's future war plans. In a letter to Colonel McCormick on July 22, 1935, Schultz specifically stated that, "Germany does not want war right now."202 This statement indicates that Schultz thought Germany had the aim to eventually wage war after 1935, which few people realized as Hitler's intent. She based this conclusion on her talks with leaders of the German military forces, such as General von Beck and General von Reichenau. All of them told her it would take Germany several years to build up its power, but none of them denied the idea of war. ${ }^{203}$

A couple of paragraphs later in this letter, Schultz hypothesized Hitler's war plan for Europe. She argued that "Hitler want[ed] to swallow Lithuania, the main part of Poland, Bohemia and Austria." ${ }^{204}$ She supported this theory with a suggestion that Germany was trying to reach a peace agreement with France in order to support the plan. ${ }^{205}$ Another article a year later had the title, "Germany seeks Deal on Austria with Mussolini: Coup in Vienna Excites Nazi Chieftains. ${ }^{206}$ Schultz described Nazi Germany as aggressively attacking Eastern Europe, which was most likely based on her conversations with higher Nazis officials and observations of the European political landscape. Her letter or articles would not have been possible in 1935 if she did not develop her extensive sources of information. There was no way of knowing how many sources Schultz had in Germany, but her well-informed articles indicate that she had a lot of them.

The average foreign correspondent in Germany from 1934 to 1936 would not be as wellinformed as Schultz about Hitler's plans for Germany. As discussed, Schultz had the necessary network of contacts to provide her with the wealth of information and communication lines. It

\footnotetext{
${ }^{202}$ Letter to McCormick July 22, 1935, WHC, Sigrid Schultz's Papers, Box 4, Folder 8. This letter was not signed by Sigrid Schultz. For a detailed explanation on why see previous footnotes.

${ }^{203}$ Letter to McCormick, July 22, 1935.

${ }^{204}$ Letter to McCormick, July 22, 1935.

${ }^{205}$ Letter to McCormick, July 22, 1935.

${ }^{206}$ Sigrid Schultz, "Germany Seeks Deal on Austria with Mussolini: Coup in Vienna Excites Nazi Chieftains,"

Chicago Tribune, PHN, May 15, 1936, 2.
} 
also gave her the ability to socialize with the high Nazi officials in order to gain some insider information on events. Schultz was prepared to operate in the fully established Nazis press system, because of her language skills, journalistic drive, and cultural background. ${ }^{207}$ However, many of the other correspondents did not have Schultz's background or upbringing to protect themselves from the Nazis. This left many of the reporters with a difficult choice of following the Nazis to at least get some of the news or to risk their careers with critical reporting. Ultimately, this was the choice of the New York Times correspondents who had very little protection, because of their owner's Jewish heritage.

The New York Times News Bureau in Berlin after 1933 was operating under the assumption that the Nazis would shut them down any day. Its bureau at the start of 1933 consisted of three main journalists with a couple of freelancers depending on the budget. Guido Enderis was still the Berlin Bureau's chief. Frederick Birchall had recently been hired as the Times' European Correspondent. He travelled all over Europe, but focused on Germany. Otto Tolishchus was also a recently hired as journalist in order to balance the bureau's writing staff. These correspondents would produce the core of articles from Germany in the 1930s. ${ }^{208}$

Frederick Birchall wrote a letter to the Times' publishers, Mr. Sulzberger, in 1933 that he “confidently expect[ed] to see circulation of both The New York Times and The London Times prohibited in Germany."209 The Times also had the added pressure of operating another business called Wide World Photos Inc. in Berlin, which sold photographs to other newspapers. By 1935, the German government started to ask the Times to prove their stockholders were of "Aryan"

\footnotetext{
${ }^{207}$ For more information, see Chapter One page 20-21.

${ }^{208}$ For a discussion on how the New York Times Berlin News Bureau developed see Chapter One.

${ }^{209}$ Frederick Birchall to Mr. Sulzberger March 21 ${ }^{\text {st }}, 1933$, New York Public Library, New York Times: Arthur Hays Sulzberger Papers, Box 6, Folder 26.
} 
descent and to replace their employees with Aryans in order to comply with German law. ${ }^{210}$ The Times also had to endure a negative campaign against their reporting. Case in point, a New York Times's staff member wrote a letter on August 12, 1935 to an editor about how some of the New York Times editions were secretly confiscated by the Germans. ${ }^{211}$ The reason was not fully explained in the letter, but it shows the German government's attitude towards the Times. A political cartoon also appeared in German that depicted the Times as a "Jewish foreign bully.", 212 In that, the New York Times had a very uneasy relationship with the Nazis from the beginning, which would have left the foreign correspondents on thin ice.

Most of this can be contributed to the fact that the New York Times was owned and published by a Jewish family. This meant that the Nazis already had prejudices against them, because they saw it as another Jewish threat in its borders. ${ }^{213}$ This only added more pressure to the journalists' situation in Germany, because it limited the available sources of information to them. Most likely, they were subjected to the same rules as Jewish journalists, who were unable to use official Nazi channels for gathering news. ${ }^{214}$ This caused the New York Times correspondents to be in an impossible situation, because any wrong move would close down the bureau.

Guido Enderis as the chief was, therefore, tasked with the job of keeping the doors open and correspondents' safe with the Nazis breathing down their necks. In some sense, this is not a figure of speech. On April 30, 1934, Birchall wrote a very causal letter to Colonel Adler about

\footnotetext{
${ }^{210}$ Translation of a letter on September 7, 1935 from the National League of German Correspondence and New Bureaus, New York Public Library, New York Times Company Records: General Files, Box 199, Folder 1.

${ }^{211}$ Robert Minner to Mr. Emery August 12, 1935, New York Public Library, New York Times: Arthur Hays Sulzberger Papers, Box 175, Folder 1.

${ }^{212}$ German political cartoon, New York Public Library, New York Times: Arthur Hays Sulzberger Papers, Box 176, Folder 5; and For another example see Der Stuermer's article on July $27^{\text {th }}, 1936$ on James Abbee (NYT photographer), New York Public Library, New York Times: Arthur Hays Sulzberger Papers, Box 174, Folder 9.

${ }^{213}$ Leff, Buried by The Times, 52-53.

${ }^{214}$ Bramsted, Goebbels and National Socialist Propaganda 1925-1945, 122.
} 
the Nazis' shopcell in their workroom and a Nazis' banner above their rented office. ${ }^{215}$ The way Enderis operated the bureau heavily influenced how the New York Times reported from Berlin, because he helped to manage what news was sent back to the United States. Most likely, he would have had the power to kill any story or at the very least delay any correspondents' stories in order to make it less relevant to the situation in Germany. This would help him manage the relationship between the New York Times and the Nazis, because he could have shaped the reporting to be moderately critical on Germany and stay off the Nazis' press radar. Ultimately, the answer to how moderate he was on the Nazis' actions lays with his reporting after 1933.

Leff argues that Guido Enderis was known for being sympathetic towards the Nazis' point of view, which she contributed to his long residency in Berlin since World War I. ${ }^{216}$ This cannot be deduced fully from his articles, and more importantly, Leff ignores the full effects of him staying in Germany during the first World War. The fact that Enderis remained in Germany during it meant that he had some experience working with a hostile government. Enderis was classified as an internee after the United States entered the war; however, he was only required to live in the Adlon Hotel and report to the police once a day. ${ }^{217}$ Clearly, he had the skills to work with the government in order create a tolerable situation for himself and his newspaper. The reason Enderis may appear has pro-German was the fact he chose to work within the press rules in order to remain in Germany, while other correspondents pushed against them. Leff did not

\footnotetext{
${ }^{215}$ Frederick Birchall to Colonel Adler April 30, 1934, New York Times: Arthur Hays Sulzberger Papers at the New York Library, Box 112 Folder 7. Birchall does not provide the first name of the Colonel. Most likely, it was Julius Ochs Adler, who served in the army during the first World War I. After he returned to the United States, he was made the general manager of the New York Times. For more information, see David W. Dunlap, "1935: A Family Battle for Succession," NYT, November 5, 2015, https://www.nytimes.com/2015/11/05/insider/1935-a-familybattle-for-succession.html?_r=0

${ }^{216}$ Leff, Buried by The Times, 55.

${ }^{217}$ E.L.J. [Edwin L. James] to Mr. Sulzberger October 23, 1940, New York Times: Arthur Hays Sulzberger Papers at the New York Library, Box 112 Folder 7.
} 
entertain this possibility about Enderis; whiles less active and vocal as a journalist, his efforts helped to keep the New York Times open.

The number of articles Enderis published on Germany dropped from about 84 articles in 1933 to 40 in 1934 and his demeanor towards the German situation softened. ${ }^{218}$ In August of 1934, Enderis published an article directly after Hitler consolidated his power in Germany in the aftermath of President Hindenburg's death. This article described how Germany was slowly descending into political uncertainty. For his opening line, he stated, "The constitutional physiognomy of the Third Reich is quietly but unerringly resolving into an image of Adolf Hitler set in the frame of a one-party totalitarian State." ${ }^{219}$ This does not describe Hitler's rise to power as beneficial for Germany. Enderis only reinforces this image by questioning Hitler's understanding "of fortifying his personal regime now that he decided to assume complete and undivided personal responsibility. ${ }^{, 220}$ Clearly, Enderis had doubts about Hitler's leadership for Germany based on his description of Hitler's rise to power. He did not outright accuse Hitler of lacking the leadership skills for his position in Germany, but his language points to Enderis' uncertainty.

In the next two years, Enderis avoided being highly critical of Hitler and the German government. The lack of criticisms about Hitler is best seen in how he portrayed Hitler's foreign policy from 1935 to 1936. In an article on February, 11, 1935, Enderis explained how Hitler reacted to a possible Anglo-French alliance by focusing on security concerns with the Soviet Union. He stated that Germany would only be concerned with the East, because it was "a

\footnotetext{
${ }^{218}$ This number was taken from the New York Times ProQuest Historical Newspaper. Guido Enderis was used as the author with Germany as the subject term.

${ }^{219}$ Guido Enderis, "Hitler Solidifies His Hold On the Reich," New York Times, PHN, October 21, 1934 , E3.

${ }^{220}$ Enderis, "Hitler Solidifies His Hold On the Reich."
} 
traditional foe of communism. ${ }^{221}$ This makes it sound naturally that Germany would have conflict with Eastern Europe and provided a reasoning to Hitler's demand for more leeway with the Treaty of Versailles.

Another article published on October 12, 1935 described how Germany was not consulted by the League of Nations on the League's sanctions against Italy. ${ }^{222}$ This article was published around the time Italy invaded Ethiopia in 1935. The League decided to impose sanctions on Italy in order to stop its aggression towards Ethiopia. ${ }^{223}$ Enderis did not address the fact that Germany already left the League in 1933 . He argued that Germany may follow Roosevelt's new principle of neutrality, where the US could trade with "all belligerents," in reaction to the lack of consultation. ${ }^{224}$ Enderis legitimized Germany's reaction by referring to Roosevelt's and Hitler's foreign policy together. In both of these articles, Enderis was less critical of the Third Reich and showed his new, softened stance on German foreign policy.

There is no definitive reason why Enderis started to pull back on his critical writing. Before making a judgement on Enderis's reporting, it is important to note that he did criticize the Nazi Party in some of his published articles. His article on March 8, 1936 directly questioned Hitler's long-term goals for the Rhinelands. Enderis described Hitler's speech about the Rhineland as the "boldest utterance on German foreign policy." ${ }^{225}$ Enderis also stated, "that the Rhineland zone would be Hitler's next point of attack after the proclamation of conscription a year ago was no secret to those familiar with the intense passion with which he pursued his goal of completely restored German territorial integrity." ${ }^{226}$ His description of Hitler's foreign policy

\footnotetext{
${ }^{221}$ Guido Enderis, "Hitler Sees Soviet as Peace Menace," New York Times, PHN, February 11,1935, 6.

${ }^{222}$ Guido Enderis, "League Firmness Surprises Berlin," New York Times, PHN, October 12, $1935,10$.

${ }^{223}$ Fischer, Nazi Germany, 409-410.

${ }^{224}$ Enderis, "League Firmness Surprises Berlin."

${ }^{225}$ Guido Enderis, "Versailles Curb Broken," New York Times, PHN, March 8, 1936, 1.

${ }^{226}$ Enderis, "Versailles Curb Broken."
} 
goal clearly shows that Hitler intended to continue grabbing land and to challenge the other Western nations. It also showed that he understood the implication of Hitler's actions. However, this is only a couple of paragraphs among many that discussed how Germany continued to work with other Western nations to keep the peace through collective security. ${ }^{227}$ Enderis's reporting cannot be clearly defined as supporting the Nazis regime. It can be seen as uncritical, which may have been his intention so he could work with the Nazis and keep the New York Times operating in Berlin.

Enderis chose to work with the German press rules instead of challenging them, which can be seen in his lackluster, uncritical articles about Germany. It is also very different from Schultz's choice to work around the German press system. Enderis's choice should not be solely defined as too pro-German like in Leff's argument, because his working relationship with the Germans helped to keep the Times open. ${ }^{228}$ Enderis's experience showed that somewhat following the Nazis' rules could be a useful method of reporting. The fact remains that Enderis's efforts allowed the bureau to remain open in the mid-1930s; thus, allowing other New York Times correspondents to keep reporting.

The New York Times correspondents, Otto Tolishchus and Frederick Birchall, were meant to balance Enderis's reporting by providing articles with a critical perspective on the Nazi regime. ${ }^{229}$ It is important to note that between 1934 to 1936 most of their critical articles were not "buried" in the back of the Times. Tolischus had 52 front page articles about Germany's situation, while Birchall had 77 front page article in the New York Times. ${ }^{230}$ This does not mean that Germany's situation was fully described in the newspapers, because it averaged to about 43

\footnotetext{
${ }^{227}$ Enderis, "Versailles Curb Broken."

${ }^{228}$ Leff, Buried by The Times, 53-56.

${ }^{229}$ Leff, Buried by The Times, 53-56.

${ }^{230}$ This number was created by using the ProQuest Historical Newspaper for the New York Times. I searched each of the correspondents' name as the author and Germany as a key term.
} 
front page articles a year. Leff argues that the New York Times purposely avoided publicizing Jewish issues in Germany, because it would cause the paper to appear as a Jewish newspaper focused only on the Jewish plight in Germany. ${ }^{231}$ This argument is true, but it ignores what actually appeared on the front page of the New York Times and how it came to be published in the newspaper. A correspondent does not need to write about all political, social, and economic issues in Germany in order to signal its descent into an authoritarian state.

An illustrative case in point is Otto Tolischus's front page articles about foreign press issues in Germany. His article published on January 5, 1935 explained how foreign leaders were becoming worried about Germany, because the foreign press was “accused of spreading 'lies' about Nazi Germany or exaggerating “incidents."232 Tolischus had a strong, detailed description on how the Nazis were treating some of the foreign press. He depicted the situation by describing it as "a violent campaign against the foreign press." 233 Later on, he stated that a "similar campaign against the foreign press preceded the anti-Jewish boycott in 1933 and the purge of June 30, 1934. ${ }^{, 234}$ His article indicates that he was aware of pattern emerging against the foreign press in Germany, which influenced their reporting. It also shows that he thought more antiJewish policy might be on the horizon. Tolischus does not provide any details on how far the Nazis censored the press, but it highlights why and when they decided to influence the news. Therefore, Tolischus showed how the Nazis were attempting to legitimize their actions for the other Western nations by keeping the public opposition to a minimum through the media.

A couple of months later, Tolischus published other articles that described how freedom of the German press was disappearing under the Nazis. This did not directly affect the foreign

\footnotetext{
${ }^{231}$ Leff, Buried by The Times, 52-53.

${ }^{232}$ Otto D. Tolischus, “Germany Nervous After Nazi Rally as Rumors Spread,” New York Times, PHN, January 5, 1935,1 .

${ }^{233}$ Tolischus, "Germany Nervous After Nazi Rally as Rumors Spread."

234 Tolischus, "Germany Nervous After Nazi Rally as Rumors Spread."
} 
correspondents, but an important source of local information. On April 26, 1935, Tolischus's published an article about how the Nazis were dismissing local editors and closing the remaining independent local newspapers. He argued that the newspapers were crushed by three press laws, because the German government thought that these newspapers were control by "special and anonymous interests. ${ }^{, 235}$ Tolischus was precise about how this would affect the German press. In his opening line, he stated the orders were "designed to make the National Socialist press supreme" in Germany. ${ }^{236}$ Tolischus also asserted that "a morsel of news or argument [could] not [be] found in any Nazi newspaper." ${ }^{237}$ He even stated that, "German press is not the voice of the German people." ${ }^{238}$ Essentially, Tolischus described how Germans lost the freedom of their press, which, in turn, compromised the local information available to correspondents. His criticism of the Nazis' press policy did not stop either, in fact it only grew in the next year. Tolischus critical reporting was also made possible by Enderis's work with the Nazis, which kept the New York Times Berlin bureau open.

In August of 1935, Tolischus published another article that described how the Economic Minister, Dr. Hjalmar Schacht, complained to Hitler about his speech being censored in the German press. According to Tolischus, his speech "denounced the disturbances of German business by National Socialist extremists, economic dilettantes and saboteurs.. ${ }^{239}$ Tolischus argued that it "developed today into a thinly disguised conflict between Dr. Schacht and Dr. Joseph Goebbels, Propaganda Minister," over freedom of speech. ${ }^{240}$ The German government

\footnotetext{
${ }^{235}$ Otto D. Tolischus, "Germany Begins a Drive to End Non-Nazi Press," New York Times, PHN, April 26, 1935, 1. Schacht did not fully disagree with the Nazis' policy to pharse out Jews from the German economy. He preferred the government to take legal action against them instead of destroying them. See Evans, The Third Reich in Power, 384385 .

${ }^{236}$ Tolischus, "Germany Begins a Drive to End Non-Nazi Press."

${ }^{237}$ Tolischus, "Germany Begins a Drive to End Non-Nazi Press."

${ }^{238}$ Tolischus, "Germany Begins a Drive to End Non-Nazi Press."

${ }^{239}$ Otto Tolischus, "Dr. Schacht Defies Reich's Censorship," Chicago Tribune, PHN, August 24, 1935, 7.

${ }^{240}$ Tolischus, "Dr. Schacht Defies Reich's Censorship."
} 
clearly wanted to project an image of peaceful governing and its policies being whole-heartedly supported to the press. Therefore, Tolischus provided the evidence to question if the German newspapers or even the official Nazi government message reflected the situation in Germany. It also showed that there was some disagreement among the German governmental official about the Nazis' agenda. More importantly, the German government was attempting to keep it silent.

These articles show how the local German press was manipulated to follow the Nazis' guidelines. There is no definitive way of knowing who read these Tolischus's articles in the newspapers, but they were attacking how the Nazis shaped its media image of Germany to the world. Tolischus would not have been able to write these articles if he had not been an observant reporter and capable of working around the press system. The New York Times showed its support by placing almost all of these articles on the front page of its newspaper expect for the last one discussed. ${ }^{241}$ It was attempting to communicate some aspects of how the Nazis were changing Germany into an authoritarian state despite its risky situation. But, Otto D. Tolischus was not the only journalists it employed who wrote critical articles of the Nazis and Germany.

Frederick T. Birchall was the other New York Times foreign correspondent whose reports from Nazi Germany often appeared on the front page. Leff described his reporting as being wellknown for its criticism of Nazi Germany. In fact, Arthur Sulzberger commented that Birchall's writing added a sense of legitimacy to the New York Times, because of the Pulitzer Award he received in 1934 for his reporting in Germany. ${ }^{242}$ An illustrative case is his article published on July 25, 1935, in which he accused the Nazis of abusing foreign correspondent in order to cover

\footnotetext{
${ }^{241}$ Another example of Tolischus's critical articles examine the ones about the German economic situation. He examines how the rearmament program affected the economy. See Otto D. Tolischus, "Berlin Issues Bids to April 27, talk on the Reich's Debts," New York Times, PHN, April 15, 1934, 1.; Otto D. Tolischus, "Germany Seizes Revenue Pledged for Dawes Loan," New York Times, PHN, July 18, 1934, 1; and Otto D. Tolischus, "Reich Threatens British Trade Ban," New York Times, PHN, June 22, 1934, 1.

${ }^{242}$ Mr. Sulzberger to Mr. Birchall on May 1, 1933, New York Times, New York Times: Arthur Hays Sulzberger Papers, Box 112 Folder 7.
} 
up anti-Semitic events. Birchall argued that the German press described themselves as victims of "the foreign campaign of lies." ${ }^{243}$ He goes on to state that "some form of reprisal may be attempted upon some who have reported what they saw plainly. ${ }^{244}$ Reprisal was not fully defined by Birchall in his article; however, it indicated that the German government was taking some action against foreign correspondents. More importantly, it suggests how the Times legitimized its general reporting about Germany through the use of Birchall's notoriety and article placement.

Another article by Birchall on April 21, 1935 described how the Nazis claimed that other Western nations lacked the right to judge Germany. This article was published when the League of Nations attempted to place sanctions on Germany due to its rearmament program, which Hitler decided to speed up. Birchall explained how Germany position has been "converted into open, active antagonism." ${ }^{245} \mathrm{He}$ argued that "nothing [was] left to prevent the division of Europe into tow hostile camps each arming to top capacity." ${ }^{246}$ This article described how Hitler challenged the status quo in Europe and how it caused political instability. Thus, Birchall's reporting became more observant of what was happening in Germany after Hitler solidified his power in August of 1934. His articles detailed how the Nazis aggressively implemented their goals; however, how did he avoid the German censors?

Birchall was the Chief European Correspondent for the New York Times, which meant he had to travel in and out of Germany to cover the rest of Europe. Some of the other cities he

\footnotetext{
${ }^{243}$ Frederick T. Birchall, "Nazis Threaten Foreign Reporters for 'Lies' on Anti-Semitic Drive," New York Times, PHN, July 24, 1935, 1.

${ }^{244}$ Birchall, "Nazis Threaten Foreign Reporters for 'Lies' on Anti-Semitic Drive."

${ }^{245}$ Frederick T. Birchall, "Germany Rejects Verdict of League on Arms Violation," New York Times, PHN, April $21,1935,1$.

${ }^{246}$ Birchall, "Germany Rejects Verdict of League on Arms Violation."
} 
frequented were Geneva and London. ${ }^{247}$ Leff did not fully analyze Birchall's unique traveling situation and what it meant for the New York Times. She simply wrote that Enderis's relationship with the German government helped Birchall to travel around Europe and still report from Germany. ${ }^{248}$ Essentially, Leff acknowledges the correspondents' situations and roles, but failed to explore the full implications on their articles. Birchall's traveling put him in an awkward position, because he needed the German government's permission to travel back and forth to Germany. If the Nazis were to take one of his articles the wrong way, his career in Germany could be ended, because the Nazis could easily deny him reentry. However, traveling also allowed him to send his material in other countries and avoid any censors. He was one of the few New York Times correspondent who mentioned sending confidential material to the US after leaving Germany's borders. ${ }^{249}$

Birchall also attempted to protect his name in 1936 by having the publisher use other names or remove his byline from the articles. He never mentioned his aliases, which means that many of his articles cannot be traced. ${ }^{250}$ Nevertheless, his continuation of critical articles under Birchall is proof that the New York Times's relationship with the German government was at least functional at the start of the Nazi regime. More importantly, it showed that the relationship and Enderis's role needs to be examined closely in order to understand fully how the Times reported from Berlin. Leff only examined the final product of the newspaper without considering how correspondents changed their reporting in respects to this relationship. The number of

\footnotetext{
${ }^{247}$ For examples of articles published in other cities see Frederick T. Birchall, "League Censures Germany: Moves to Apply Sanctions for Future War Threats," April 18, 1935, New York Times, PHN, 1; Frederick T. Birchall, "Widespread Air Alliances are Developing at Geneva as League Gets Arms Issue," April 16, 1935, New York Times, PHN, 1; Frederick T. Birchall, "Reich Held Ready to Strike Bargain on Arms at Geneva," New York Times, PHN, 1; and Frederick T. Birchall, "Vienna Quiet Again; Nazis Woo Rebels," New York Times, PHN, 1.

${ }^{248}$ Leff, Buried by the Times, 55-61.

${ }^{249}$ Sulzberger to Birchall on January 10, 1936, New York Public Library, New York Times: Arthur Hays Sulzberger Papers, Box 174, Folder 9.

${ }^{250}$ E.LJ [Edwin James]. to Mr. Sulzberger on January 4, 1936, New York Public Library, New York Times: Arthur Hays Sulzberger Papers, Box 174, Folder 9.
} 
articles about Germany by Birchall, Tolischus, and Enderis showed how the Times needed to change its reporting after Hitler took full control.

The only aspect that can be certain is 134 articles were published on the front page of the newspaper by two critical journalists, which does not amount to much for a daily newspaper. One should consider, though, that the New York Times first priority was to cover domestic news. The entire bureau's staff was also well aware of their situation with the German government's anti-Jewish policies. Each one played a defined role in this situation that affected their individual reporting. Overall, the New York Times was able to fight off any ban, expulsion, and arrest by the Nazis; however, it came at the cost of having fewer critical articles available for the newspaper.

The correspondents in Germany were not the only ones that faced press restrictions from 1934 to 1936 due to Europe's political situation. Hitler kept violating the terms in the Versailles Treaty throughout the 1930s in order to make Germany strong again and solidify his power with the German people. European countries depended on the Treaty's terms to protect the fragile peace. France and Great Britain attempted to work with Hitler by appeasing most of his demands, because domestic issues from the Great Depression were more pressing. ${ }^{251}$ These countries' relationships with Germany were an important indicator of how strained Europe's political atmosphere was becoming in the 1930s. The way foreign correspondents were treated in other European countries showed how concerned they were about Germany and for the chance of war.

Both the Chicago Tribune and the New York Times had large news bureaus in London; it was one of the few cities that did not show signs of attempting to control foreign correspondents'

${ }^{251}$ Evans, The Third Reich in Power, 615-617. 
articles. $^{252}$ It seemed to be an avenue for correspondents to send censor-free communications in the early 1930s. In fact, Sigrid Schultz described in a letter from 1934 how the Chicago Tribune's London office was efficient at cabling her stories back to the United States with the correct wording. ${ }^{253}$ London correspondents did not mention any issues about producing stories expect for ones about the British Royal family. In the mid-1930s, the British Royal family was experiencing a scandal, because King Edward VIII was courting Wally Simpson who was American and divorced. The Chicago Tribune's chief London correspondent, David Darrah, published an article on October 23, 1936 that described how the British government threatened the British press in order to enforce an "unofficial" censorship. ${ }^{254}$ Besides local censorship, the London correspondents did not voice any real concerns about their reporting situation; thus, making it a life line for correspondents in heavily censored areas like Germany. Nevertheless, few correspondents were able to use the lifeline.

The simple answer is that London was off on an island; thus, correspondents could not easily send material to their respective countries. Schultz would not have set up a communication route to the US in Prague if she could simply phone her stories to London from Berlin. Most likely, a correspondent in continental Europe would send a human messenger to London or travel outside of their respective country for an uncensored communication line to Great Britain. Safe

\footnotetext{
${ }^{252}$ For a list correspondents stationed in London for the New York Times see Leff, Buried in the Times, xiv-xv. For examples of correspondents stationed in London for the Chicago Tribune see David Darrah, "By David Darrah," Chicago Tribune, PHN, December 11, 1936, 1; John Steele, "20,000 Jobless Riot in London; Police Stoned," Chicago Tribune, PHN, October 28, 1932, 1; Sam Brewer, "London Eases Congestion," Chicago Tribune, PHN, September 26, 1937, b8; Ann Whittigham, "London Offers Gay Spectacle at Tulip Time," Chicago Tribune, PHN, May 31, 1936, d6; and Frank Swinnerton, "London's Kindest of Editors Lauded as Memorial Tribute," Chicago Tribune, PHN, August 2, 1930, 10.

${ }^{253}$ Sigrid Schultz to Mr. Scharachug August 13, 1934, First Division Museum, Chicago Tribune Archive, I-62 Foreign Correspondents 1914-1955, Box 8, Folder 9.

${ }^{254}$ David Darrah, "Reveals Threat to British Press in Simpson Suit: How Unofficial Censorship was Imposed is Told," Chicago Tribune, PHN, October 23, 1936, 3. Darrah started with the Chicago Tribune when he succeeded Floyd Gibbons as editor of the Paris Tribune in 1927. In the 1930s, he would report from such countries as London and France. He was one of the few reporters that remained in France after Germany occupied its borders. For more information on Darrah, see Wendt, Chicago Tribune, 473, 603-605.
} 
communication resources in continental Europe became crucial for all correspondents in order to publish uncensored news and to stay ahead of the developing events. Ultimately, the individual correspondents had to evaluate their available communication outlets on whether or not they could be trusted.

For many correspondents, France became their cheap and quick communication route, but it did have another cost. France implemented several ways to censor foreign correspondents by 1935 . The Chicago Tribune Paris correspondent, Edmund Taylor, described in a letter on April 30, 1935 how the French government thought that censorship could help prevent foreign attacks. He stated that "the French are apt to fall into occasional fits of hysteria in which they lock upon every foreigner as a probably spy." ${ }^{255}$ The reason for the censorship and other press rules in 1935 could be contributed to France's and Germany's tense relationship after World War I. Throughout the 1920s and 1930s, France attempted to secure itself from another potential German attack on their land. ${ }^{256}$ It could also be attributed to France's host of domestic issues from the Great Depression that the government struggled to solve and the country's reluctance to be pulled into yet another war. ${ }^{257}$

The effects of French censorship on the correspondents' writing remain unclear based on the correspondents' articles and private papers; however, they say plenty about their communication lines. The Paris News Bureaus of the New York Times and Chicago Tribune had limited options to communicate articles back to the United States by 1935. In 1934, Schultz wrote a letter that explained how the New York Times correspondent, Frederick Birchall, sent his articles through Paris with orders to the cable editors not to have any of his writing touched or

\footnotetext{
${ }^{255}$ Edmund Taylor to Colonel April 30, 1935, First Division Museum, Chicago Tribune Archive, XL 317 Kirkland \& Ellis Files II, Box 3, Folder 3.

${ }^{256}$ Richard Overy, Origins of the Second World War, $3^{\text {rd }}$ ed., Seminar Studies in History, (Harlow, England and London: Pearson Longman, 2008), 3-10.

${ }^{257}$ Evans, The Third Reich in Power, 573, 617.
} 
changed. ${ }^{258}$ Clearly, the New York Times at least had some issues with the French office changing their text while cabling it back to the US. For the correspondents in Germany, one wrong word could have meant expulsion or, even worse, being arrested by the Nazis.

The Chicago Tribune correspondents in Paris did not fare much better than the Times. About a year later, the Tribune correspondent for Paris, Edmund Taylor, wrote several letters that explained how he could avoid French censorship by phoning stories to London. ${ }^{259}$ He was the correspondent discussed earlier who had issues with getting his "mailer stories" across German borders in France. ${ }^{260}$ In this letter, he does not provide a reasoning why the French government left the phone lines still available; in fact, he does not understand it himself. ${ }^{261}$ Ultimately, the French government was simply getting ahead of itself by placing restrictions on foreigners, which would not be abnormal in a war situation. This showed the kind of anxiety the French had over the political atmosphere in Europe by 1935, but also how it affected communication lines for foreign correspondents. This did not only impact correspondents in France, but rippled across to other news bureaus who had limited communication lines.

The correspondents assigned to Soviet Union were the ones with the most limited communication lines and source networks. It is well-known that the Soviet government heavily censored its domestic newspapers throughout the 1930s in order to control information in it's the country. ${ }^{262}$ The foreign correspondents had to work within a strict press censor system enforced

\footnotetext{
${ }^{258}$ Sigrid Schultz to Mr. Scharachug August 13, 1934.

${ }^{259}$ Edmund Taylor to Colonel [McCormick] April 30, 1935; Edmund Taylor to Colonel [McCormick] May 2, 1935 , First Division Museum, Chicago Tribune Archive, XL 317 Kirkland \& Ellis Files II, Box 3, Folder 3. Edmund Taylor, Two-page document about French press censorship, n.p., First Division Museum, Chicago Tribune Archive, XL 317 Kirkland \& Ellis Files II, Box 3, Folder 3. This document was unsigned and not dated. It may have been a draft of an article. Most likely, Edmund Taylor wrote this document in 1935, because he mentioned the issue in his other letters about French censorship.

${ }^{260}$ For a detail discussion of this incident see Chapter One page 48 to 49 .

${ }^{261}$ Edmund Taylor, Two-page document about French press censorship.

${ }^{262}$ For general information on Soviet censorship see Jan Plamper, “Abolishing Ambiguity: Soviet Censorship Practices in the 1930s," Russian Review 60, no. 4 (Oct 2001): 526-44.
} 
by the Soviet government, but the Chicago Tribune and New York Times correspondents had minimal interaction with it throughout the 1930s. Both of them were unable to assign a steady correspondent to the Soviet Union throughout the 1930s. ${ }^{263}$

The Chicago Tribune did not have a correspondent stationed in the Soviet Union, because the assigned one, Donald Day, could not enter the country. Therefore, Day became the Northern European foreign correspondent for the Chicago Tribune. He would report from countries such as Poland and Latvia in order to get the news from the Soviet Union. ${ }^{264} \mathrm{He}$ argued that the Soviet government refused to allow him in the country since 1920, because of his critical writing and attitude towards communism. He also did not sign the press agreement that he would submit his work to Soviet censors. ${ }^{265}$ However, this was Day's opinion on why he could not enter the country. The Soviet government could have had any number of issues with Day's reporting. At any rate, the Chicago Tribune was unable to receive direct news about how the Soviet Union reacted to Nazis' policies unless it was filtered through Latvia. The New York Times did not fare much better with keeping a correspondent in Moscow. Their correspondent Harold Denny was expelled from the Soviet Union in 1937. It remains unclear why Denny's articles were cause for him to be unwelcomed in the Soviet Union. ${ }^{266}$ Ultimately, it left the Times without a steady reporter in Moscow until 1939.

The treatment of reporters in other European countries is somewhat of an indicator of how tense the political atmosphere was becoming in the 1930s. The shifts in the political

\footnotetext{
${ }^{263}$ For list of reporters in Eastern Europe for the New York Times see Leff, Buried in the Times, xiv-xv.

${ }^{264}$ For an example of Day's article from the cites see Donald Day, "Moscow Masses Two Armies for Invasion of Poland," Chicago Tribune, September 28, 1938, 1; Donald Day, "Polish-German Alliance Forms Against Russia," Chicago Tribune, February 24, 1938, 4; Donald Day, "Russian Drive Checked After 8 Day Battle," Chicago Tribune, February 10, 1940, 1.

${ }^{265}$ Donald Day, Onward Christian Soldiers: 1920-1942: Propaganda, Censorship and One Man's struggle to Herald the Truth (Torrance, Calif: Noontide Press, 1982), iv-v, 107-109.

${ }^{266}$ Sulzberger to Denny October 6, 1937 and Telegram on September 29, 1937, New York Public Library, New York Times: Arthur Hays Sulzberger Papers, Box 208, Folder 16.
} 
situation of Europe strongly affected correspondents' positions and, subsequently, communication outlets. France became worried that the country maybe infested with correspondents as foreign spies. The Soviet Union did not provide an opportunity for the newspapers' correspondents to report directly from the country. Great Britain was a lifeline for censor-free communication; however, it was out of reach for most correspondents. Ultimately, this era of appeasement measures began to change in 1936. This was when the European political atmosphere became politically tense, because the countries descended into a fast pace rearmament race.

By the end of 1936, Europe's political atmosphere reached a crucial turning point that set it on path for war. On March 29, 1936, Hitler remilitarized the Rhineland with the approval of the German people. A few month later, Spain was in the middle of a Civil War. Mussolini and Hitler provided support to the Spanish Fascist; therefore, it helped to cement a friendship and alliance between Germany and Italy. More importantly, the Nazis were becoming more aggressive in their foreign policy by the start of 1937, because they shifted their focus from maintaining peace with other European to gaining new "living space" and quickened their rearmament. Hitler's aggressive foreign policy can be contributed to his perception that other European nations would do anything to avoid war. This led to such events as the annexation of Austria in 1938, Germany's seizure of the Sudetenlands and eventual full invasion of what remained of Czechoslovakia in early $1939 .{ }^{267}$

The press regulations and censorship also increased progressively, but did not start until after the Nazis finished hosting the Olympics of 1936. The Nazis used the Olympics as a stage to influence the world's image of Germany by hiding their treatment of Jews. The foreign press regulations increased substantially after the Olympics concluded in Germany. The foreign

\footnotetext{
${ }^{267}$ Fischer, Nazi Germany, 410-415.
} 
correspondents in Germany were one of the few groups of foreigners able to see the effects of Hitler's foreign policy; however, it did not necessarily mean they were able to report it. ${ }^{268}$

Sigrid Schultz's reporting illustrates how reporters after 1936 needed to take even more extreme measures in order to keep writing critical articles, while being allowed to remain in Germany. ${ }^{269}$ It should be kept in mind that Schultz already used networks of sources and communication outlets outside of Germany. Her letters and articles after the summer Olympics indicated how much the press situation had changed in Germany. On October 1936, Schultz wrote a letter to the Tribune cable editor George Scharschug that described what happened to her editorial story on the "June Blood Purge's" history and its effects. ${ }^{270}$ This letter is referring to the Night of Long Knives in June of 1934, which was when Hitler ordered the killing of Röhm and other top SA leaders. This order allowed Hitler to further consolidate Nazis' power in Germany, because he eliminated political enemies and instilled fear. ${ }^{271}$ Schultz knew that this type of story would put her into trouble with the Nazis; therefore, she had to take steps in order to hide her authorship.

In Schultz's letter on October 1, 1936, she described how she could end up in trouble with the Nazis, because they may have been informed about her order to write the "June Blood Purge's" article and her plan to avoid being accused. First off, she planned to send a separate letter stating "no new material [was] available in Germany [,] I can't see my way to writing the

\footnotetext{
${ }^{268}$ Evans, The Third Reich in Power 1933-1939, 570-573.

${ }^{269}$ She wrote about 8 articles about the Olympics in Nazi Germany. This number was taken from Proquest Historical Newspaper by searching Sigrid Schultz as the author and Olympics as the subject.

${ }^{270}$ Sigrid Schultz to George Scharschug on October 1, 1936, WHC, Sigrid Schultz's Papers, Box 4, Folder 4. This letter was not signed by Schultz, because it described how she was avoiding the Nazis' censors. Most likely, she wrote this letter, because there was an article about the purge published about a month later and written by her pseudonym John Dickson. See John Dickson, "Democracy Surrenders: Dictatorship Crushes Freedom in Germany," Chicago Tribune, PHN, November 1, 1936, E9.

${ }^{271}$ Evans, The Third Reich in Power 1933-1939, 29-31.
} 
Blood Purge.."272 She argued this was necessary, because the Tribune's London correspondent David Darrah's written order for her to write the article was intercepted by the Nazis. She also made a point to ask for the article to be published under a different name, which "sound pretty real to our dear Nazi snoopers. ${ }^{273}$ This was the first time Schultz mentioned using a different name in order to hide her identity from the Nazis. Her reason was that "[she] want[ed] to give our readers all the dope there is, but [she is] perfectly willing to hide behind somebody's name or coat. ${ }^{, 274}$ Ultimately, this meant Schultz needed to detach herself completely from any articles that would upset the Nazis in order to remain a reporter in Berlin. If the Nazis could connect her to the articles, Schultz would have been easily expelled or, even worse, arrested.

Schultz hid her identity by using a male pseudonym, John Dickson, to write some articles. She started using this name when she published her June Blood Purge article in November of 1936. Based on her letter in October, she did not seem to pick this name herself; however, she kept it until the end of $1939 .{ }^{275}$ The use of a male pseudonym showed how male reporters were more respected when it came to writing critical articles, because it would have been easy for someone to choose a female name. More importantly, the editors recognized the importance of her work, because few of these articles were not on the front page. ${ }^{276}$ The June Blood Purge article in 1934 argued that this was when democracy ended in Germany. She also described in detail how Hitler's rule changed the lives of the average German for the worse, because of the constant fear of being arrested by the Gestapo. She argued that their "relatives and friends are silent, but the rumor of mysterious disappearances is enough to enforce the silence

\footnotetext{
${ }^{272}$ Sigrid Schultz to George Scharschug on October 1, 1936.

${ }^{273}$ Sigrid Schultz to George Scharschug on October 1, 1936.

${ }^{274}$ Sigrid Schultz to George Scharschug on October 1, 1936.

275 John Dickson, “Pledge to Czechs Broken,” Chicago Tribune, PHN, December 17, 1939, 16.

${ }^{276}$ For examples of Dickson's first page articles see John Dickson, "Germany to Put 1,500,000 Men into 'War Game," Chicago Tribune, PHN, August 7" , 1938, 1; John Dickson, "Hitler Terror Grips Nation; Unrest Mounts," Chicago Tribune, PHN, September $14^{\text {th }} 1938,1$; and John Dickson, "When Liberty Dies!," Chicago Tribune, PHN, January 8, 1939, 1.
} 
desired by the men in power." ${ }^{, 277}$ Later on, she described how these executions of SA leaders were simply a way for lesser Nazis officials to "vent their blood lust and do away with those they fear or hate." 278 In this article she showed that the Nazis' rule was built on terror and fear for everyone to see if they took the time. She continued to provide evidence to support this conclusion by using Dickson's name throughout the late 1930s.

Schultz protected her pseudonym from the Nazis by trying to make Dickson a real person who lived outside of Germany. This would be crucial for her safety, because any hard evidence that Schultz was Dickson could have easily led to her arrest. She distanced herself by doing such things as writing in her diary "Trib front page that fellow Dickson wonder who he is." ${ }^{279}$ She also signed letters under his name and approved other journalists' articles. ${ }^{280}$ She even had the editors mark the articles as published in Denmark in order to keep the ruse with the Nazis that John Dickson was an actual Chicago Tribune correspondent outside of Germany. ${ }^{281}$ All of these precautions to protect her identity after 1936 showed that even Schultz was becoming fearful of being expelled or arrested based on her articles. It also showed that simple little changes were enough to elude the Nazis before the war and keep writing. The proof is in how Schultz's second byline allowed her the freedom to write about political chaos developing in Europe for the time being; however, the Nazis continued to keep her reporting under a microscope.

On May 11, 1939, Sigrid Schultz wrote a letter to Robert McCormick about how difficult it was to send her articles from Germany. She explained how many of her articles were arriving too late in order to be of any use for the newspaper. She had to trust a mail courier to forward the

\footnotetext{
${ }^{277}$ Dickson, "Democracy Surrenders: Dictatorship Crushes Freedom in Germany."

${ }^{278}$ Dickson, "Democracy Surrenders: Dictatorship Crushes Freedom in Germany."

${ }^{279}$ Sigrid Schultz's Diary, n.p., WHC, Sigrid Schultz's Papers, Box 33, Folder 1.

${ }^{280}$ John Dickson to Robert McCormick on June $26^{\text {th }}, 1939$, First Division Museum, Chicago Tribune Archive, I-62 Foreign Correspondents 1914, Box 8, Folder 10; Roger Williams's article approved by John Dickson, n.p., WHC, Sigrid Schultz's Papers, Box 25, Folder 22.

${ }^{281}$ See footnote 276 for examples of John Dickson's articles published outside of Germany.
} 
letters, because her mail would have been stopped by the Germans. This meant that she was dependent on mail instead of telephone or cabling, which created the lag in sending her material. ${ }^{282}$ Most likely, the problem was that Schultz did not have a safe communication route after Czechoslovakia was invaded and taken over by the Nazis. This had been Schultz's main communication outlet since $1934 .{ }^{283}$ Schultz had few options to send uncensored articles in an efficient and timely manner, which made her reporting less relevant to the situation. This was not due to her choices as a journalist, because Schultz actively attempted to find ways around the German press system. Schultz was severely limited by the options available to her in Germany. Unfortunately, this was also the time when her reporting and observations were becoming more important to Americans, because it provided insight into Germany’s readiness for war.

The situation for the New York Times correspondents in Germany did not significantly change after 1936, because the company already had a precarious relationship with Nazi Germany. ${ }^{284}$ Otto Tolischus and Fredrick Birchall kept attempting to report from Germany; however, it steadily became tougher for them not to be expelled. Together, Tolischus and Birchall had about 100 front page articles published between 1936 to September of $1939 .{ }^{285}$ The only change was the number of issues the reporters had with the Nazis, which can be attributed to the lack of protection they had from Nazis' wrath.

Leff describes, for example, how Birchall was almost not allowed back into Germany to cover the Olympics for the Times. Enderis was the only reason Birchall was able to re-enter Germany in 1936. He developed a plan where Birchall left Germany for a couple days to let

\footnotetext{
${ }^{282}$ Sigrid Schultz to Robert McCormick on May 11 ${ }^{\text {th }}$, 1939, First Division Museum, Chicago Tribune Archive, ,I-62 Foreign Correspondents 1914, Box 8, Folder 10.

${ }^{283}$ For information see Chapter One page 50-51.

${ }^{284}$ Leff, Buried by the Times, 50-51.

285 These numbers were taken from ProQuest Historical Newspaper for the New York Times by searching their names as the author and Germany as the subject term.
} 
things cool down. Birchall would then return to Germany in order to write some nonpolitical pieces that would please the Nazi officials. This would allow the Nazis to forget about Birchall's earlier articles. Leff argues that this plan worked at least for the Olympics, because Birchall was able to come back to Germany. ${ }^{286}$ Clearly, Birchall was on Nazis' radar for his previous articles, which meant one wrong move could expel him indefinitely. There was no clear reason why the Nazis did not expel him like the other journalists, such as Dorothy Thompson, expect for Enderis's ability to compromise. ${ }^{287}$

Otto Tolischus was not in a much better situation with the German government. Leff shows that Toliscchus was almost expelled several times, because of his articles about the German press's situation and his conclusions about Germany's foreign policy in 1937 and 1938. His articles were offensive enough for him to be called into the German Foreign Office's press department, which meant a possible expulsion. Again, Guido Enderis was the only reason Tolischus could remain in Germany for the time being. Leff describes that Enderis talked to several German officials who were willing to look the other way on Tolischus's reporting. ${ }^{288}$

The number of issues New York Times correspondents were having in Germany suggests that their days in Germany were numbered. Enderis could only protect the correspondents to a certain point. This means that the correspondents had a choice to either keep reporting with the same level of criticism or to find a way to work within the German press rules to remain in Germany. Clearly, the Birchall and Tolischus chose the former based on their many conflicts with the Nazis. This choice allowed the New York Times for a brief period of time to report some of the news about the reality in Germany; however, it only lasted as long as Enderis had a good relationship with the Germans.

\footnotetext{
${ }^{286}$ Leff, Buried by the Times, 57-58.

${ }^{287}$ For a discussion on how Thompson was expelled in 1934 from Germany, see Chapter One page 29 to 30.

${ }^{288}$ Leff, Buried by the Times, 58-59.
} 
It became crucial between 1934 to 1939 for the correspondents to learn how far they could push the press rules in their respective countries. From 1934 to 1939, it became clear to the foreign correspondents that they were faced with a choice because they were entering a new era of journalism. They could either follow the new state press rules throughout Europe or work around them. As one can see from the Chicago Tribune and New York Times correspondents, the answer was dependent on a lot of different factors. Schultz was able to provide accurate reports, because she had the capabilities to operate under the Nazis radar. Unfortunately, the New York Times correspondents were under the Nazis' microscope from the very beginning, because of its owner.

These foreign correspondents were also seen as a potential enemy in their host countries, because they were eye witnesses with a speaking platform that could influence people. The Nazis attempted to sway the American foreign correspondents' opinion to portray a stable government to the United States. However, much of this gave way after 1936, when Hitler's foreign policy became more aggressive. This then led to a harsher campaign against the press in terms of censorship and restriction of information in order to keep a tight watch over the information.

Ultimately, the correspondent who took the risk to work around the press system provided the most accurate news. The best example of this type of reporter was Sigrid Schultz who took the risk and initiative to inform fully the American public. However, the correspondents who worked within the rules should not be completely written off, because they remained in their respective countries and reported something. The German press rules were slowly spreading across Europe, because Germany took over lands in Eastern Europe. And when the Nazis invaded Poland on September 1, 1939, it caused a significant shift in the foreign correspondents' situation, because it transformed them into war correspondents. 


\section{CHAPTER IV}

THE WAR CORRESPONDENTS FROM 1939 TO 1941

"I was the last correspondent to leave Poland and have a most complete and exclusive eyewitness story of Poland's collapse, including 20 days' experience as a refugee in east Poland, cut off from all communication. "289

Alex Small (Chicago Tribune Correspondent) on September 28, 1939

The foreign correspondents' situation completely changed the moment when the

Wehrmacht crossed the border into Poland and began their campaign against the Polish army on

September 1, 1939. ${ }^{290}$ Most correspondents found themselves operating from waring countries, which meant harsh press regulations, and even in some cases threats against their lives. The correspondents came to be seen as foreign agents who needed to be controlled. The Chicago Tribune's correspondent, Sigrid Schultz, wrote a letter on October 8, 1940 that described how desperate her situation in Berlin had become in the last couple of months. She stated, "I have violated no laws, but this constant attempt to trap me at times seemed more than I could cope with. I was even denounced as being Jewish..." ${ }^{, 291}$ A couple of paragraphs later she wrote, "It is true it is not officially proclaimed censorship, but this kind of self-imposed censorship is exceedingly hard to cope with, especially when every few days we are told we must remember the high treason and treason legislation. ${ }^{, 292}$ Schultz was facing a new level of scrutiny by the Nazis, which caused her to doubt her ability to report from Berlin and even her safety.

This was one of the first times Schultz showed that her nerves were beginning to fray under the Nazis' pressure. If the pressure affected such a veteran reporter, other reporters most likely found themselves in a similar situation. This begs the question whether correspondents

\footnotetext{
${ }^{289}$ Alex Small to Col. McCormick September 28, 1939, First Division Museum, Chicago Tribune Archives, I-62 Foreign Correspondents 1914-1955, Box 9, Folder 5.

${ }^{290}$ The German military during the Nazis era is also referred to as Wehrmacht.

${ }^{291}$ Sigrid Schultz to Colonel McCormick October 8, 1940, First Division Museum, Chicago Tribune Archives, I-62 Foreign Correspondents 1914-1955, Box 8, Folder 10.

${ }^{292}$ Sigrid Schultz to Colonel McCormick October 8, 1940.
} 
could even report from Europe after September 1, 1939. Was there any value in them risking their lives in order to send reports home? These correspondents were the few foreign witnesses to the early events in World War II. They helped to shape how the war was perceived by the American public; however, their reporting capabilities were very much subjected to the tides of the war. The correspondents' communication network became more limited from 1939 to 1941 , because few countries allowed quick and uncensored telegraphing for journalists. This compromised their ability to report up to date news about the war in Europe.

For most of 1939 to 1941 , the German army was winning the war. Germany's military strategy-blitzkrieg- or lightening war allowed the army to easily overwhelm the majority of its enemies by striking quickly to catch its enemy off guard and, thus, overwhelm its defenses. ${ }^{293}$ This strategy was also supported by Germany signing a non-aggression pact with the Soviet Union in 1939. This agreement dictated that the two nation would not attack each other and split parts of Eastern Europe. ${ }^{294}$ This strategy quickly overwhelmed Poland's and France's defenses in the beginning of war. Parts of Poland were annexed by the Soviet Union and Germany at the end of September, while France's defenses failed to repel the German forces in May of 1940 after six weeks of fighting. This led it to part of France becoming a puppet state for the German government, which was known as Vichy France and led by Marshal Philippe Pétain. The other part of France had some autonomy from Vichy France. ${ }^{295}$ This effectively left Great Britain alone to wage a war against Germany in one of the most deadly aerial fights. By June of 1940, Great Britain's war efforts were only sustained by the United States' Lead-Lease Act of 1941

\footnotetext{
${ }^{293}$ Richard Overy, Origins of the Second World War, $3^{\text {rd }}$ ed., Seminar Studies in History, (Harlow, England and London: Pearson Longman, 2008), 3-4.

${ }^{294}$ Overy, Origins of the Second World War, 76.

${ }^{295}$ Richard Evans, The Third Reich at War 1939-1945 (New York: Penguin Books, 2008), 133-135.
} 
and modifications to the US Neutrality Laws, which provided access to the much needed military supplies. $^{296}$

By December of 1940, Hitler was confident enough to make plans for the invasion of the Soviet Union, otherwise codenamed as "Operation Barbarossa." This campaign was initially successful for the German army; it drove deeply into Soviet territory. Nevertheless, the Soviet Union never collapsed and continued to fight. The German army was also plagued by supply line issues. About a year after this invasion, this war became a true World War after the Japan's attack on Pearl Harbor. To support its alliance with Japan, Germany would declare war on the United States on December 11, 1941. ${ }^{297}$

The American public was desperate for any news about how the war was developing in Europe between 1939 and 1941. The newspapers were one of the few sources of information; however, the foreign correspondents' reporting was subjected to the tides of war. Many of them had to flee their respective countries for their own safety. This opens up the question how the correspondents could still report about Europe, while remaining in their respective countries. Ultimately, the correspondents, who remained in Europe, had a choice to make about their reporting. They could either conform to the government's press rules, which gave them some sense of security. The other option would be to find a way around them without being expelled.

A judgement should not be passed on either choice, because reporting from war engulfed Europe required journalists to step into a new role of war correspondent. This was not a simple change of title, but required the reporters to learn how to write under war conditions and with few resources. As the German army took over Europe, the countries with efficient and censorfree communication for journalists' articles decreased. The correspondents would have to leave

\footnotetext{
${ }^{296}$ Overy, Origins of the Second World War, 83-85.

${ }^{297}$ Overy, Origins of the Second World War, 85-88, 90-92.
} 
the German-occupied territories and travel to neutral countries, however, there was no guarantee of being allowed back into their respective countries. Even more so, the reports may never make it to the United States in time to be relevant news. This meant that most of the correspondents were operating in an impossible situation, which left many of them useless or barely able to report the basic news. Thus, the image of the war was shaped by not only the correspondents' choices in reporting, but also their luck and location.

The remaining correspondents of both the Chicago Tribune and New York Times Berlin News Bureaus were able to report until Germany declared war on the United States on December 11, 1941. After the declaration of war, the foreign correspondents were effectively enemy aliens, which forced the news bureaus to close. The next section highlights how the correspondents' situation changed after war was declared in 1939 and how chance influenced their ability to keep writing for the American public.

It should be no surprise how quickly Chicago Tribune correspondent, Sigrid Schultz, reacted to the German invasion of Poland and her efficiency in reporting the breaking news. She woke up another fellow American foreign correspondent, William Shirer, at 6 A.M. on September 1, 1939 by telephone in order to inform him that the war had begun. ${ }^{298}$ Clearly, she wanted to get the word out to other foreign correspondents. Schultz started her reporting on the war with the same level of enthusiasm and journalistic drive as beforehand. In fact, she wrote one of the first front page articles about the German invasion of Poland on September 1, 1939, which meant her report had to be written and sent before the newspapers were printed. ${ }^{299}$ Her

\footnotetext{
${ }^{298}$ William L. Shirer, Berlin Diary: The Journal of a Foreign Correspondents 1934-1941 (New York: Groseet \& Dunlap, 1940), 155.

${ }^{299}$ Sigrid Schultz, "Germany Takes Danzig; Navy Blockades Gdynia," Chicago Tribune, ProQuest Historical Newspapers (PHN), September 1, 1939, 1. It is important to note that this article was sent by Schultz with enough time for it to be published the day of the invasion. This would have required her to evaluate the situation and write an article in a manner of hours.
} 
journalistic energy quickly changed over the next months into depression and somewhat hopelessness from the strict press situation in Germany. Schultz had never exhibited such an attitude about her situation before 1939, which suggests that even veteran reporters could not function well under Nazis' wartime press rules.

Sigrid Schultz wrote fewer and fewer articles for the Chicago Tribune from 1939 to 1941. She published 375 articles about the situation in Germany in this time span. This number may seem large, but it does not even compare to her other years. Schultz wrote 936 articles from 1936 to 1939 and 812 articles from 1936 to $1939 .{ }^{300}$ This large decrease in her writing can be attributed to how quickly the press's situation fell apart in Germany due to the demands of war and the German wartime culture. The correspondents' ability to report from German-controlled territories was slowly restricted by its war time measure.

Schultz's situation in Germany was changed by its wartime measures over a couple of months. Firstly, the usual communication routes that served Schultz and the rest of the Chicago Tribune correspondents were cut off by October. Schultz wrote a letter to the Chicago Tribune editor, George Scharachug, on October 25, 1939 that discussed how "the whole of [her] carefully built up organization went to pieces. ${ }^{301}$ She described an incident where the Press Wireless, a local messaging company, claimed that her article could be sent to the United States from Berlin in a matter of an hour; however, it was delayed to the point where it became useless. A couple of hours after sending it, she received several phone calls from the post office about her article not being sent and there was also no way of contacting the Press Wireless about it. ${ }^{302}$ The post office

\footnotetext{
${ }^{300}$ These numbers were taken from the ProQuest Historical Newspapers database for the Chicago Tribune. These numbers were taken by inputting Sigrid Schultz as the author and Germany as the subject. The search does not include her articles for pseudonym John Dickson. She wrote about 27 known articles from 1933 to 1939 under the name John Dickson.

${ }^{301}$ Sigrid Schultz to Mr. George J. Scharschug October 25, 1939, First Division Museum, Chicago Tribune Archive, I-62 Foreign Correspondents 1914-1955, Box 8, Folder 10.

${ }^{302}$ Sigrid Schultz to Mr. George J. Scharschug October 25, 1939.
} 
had to be run by low level Nazis officials, who would had some sort of orders from the government to delay Schultz's message back to the US. Schultz's solution to avoid such issues was to set up a telephone line from Berlin to Copenhagen, Denmark. She had to pay a relay man in Copenhagen about 100 dollars a month to send Chicago Tribune's articles to the United States. Unfortunately, this was not the only issue Schultz encountered after the German invasion of Poland. ${ }^{303}$

Schultz also complained to Scharachug about how the OKH did not allow her to visit the front. This letter does not give an explicit reason why Schultz was kept away from the front, but suggests it may be an issue with the fact she was a woman. Therefore, Schultz had to hire a relatively unknown journalist, John Raleigh, to cover stories from the front. Raleigh could hardly speak German and had to ride a bicycle across Germany to even arrive at the Tribune's Berlin office. Schultz stated that he was knowledgeable about the military, but his lack of German hurt his ability to report. ${ }^{304}$ She did not have much of a choice since he was allowed near the front and she was denied. The Germans also may not have wanted Schultz on the front, because of her previous articles. These two reporting issues affected how Schultz was able to communicate and to find sources for her articles, which affected her ability to write them. It was up to the individual correspondent to find ways around them, even if it meant hiring a non-qualified, male journalist.

Schultz's other correspondence with Scharschug and Chicago Tribune editor Maloney illuminates a more important problem for the newspaper. Schultz wrote a telegram on November 29, 1939, in which she described her worry about the Chicago Tribune publishing a falsified report sent from Europe. She stated that the fabricated article was about "Hitler's bodyguards'

\footnotetext{
${ }^{303}$ Sigrid Schultz to Mr. George J. Scharschug October 25, 1939.

${ }^{304}$ Sigrid Schultz to Mr. George J. Scharschug October 25, 1939.
} 
bullet-proof vests and Fritsch's death., ${ }^{305}$ Based on her description, there is no way of knowing if the article was published by the newspaper. The publication of this article did not worry Schultz as much as its threat to the Tribune's telephoning privileges in Germany. She did not know who could be the imposter, but anything sent by him could endanger the foreign correspondents. ${ }^{306}$ If the Tribune lost easy access to the telephone, the last remaining express communication route would be firmly cut off. In the extreme case, a fake article could cause the correspondents to be faced with expulsion from Germany or criminal charges. This only added to the atmosphere of paranoia and worry for the correspondents. Unfortunately, the situation did not improve for Sigrid Schultz, but only became more dangerous.

In February 10, 1940, Sigrid Schultz wrote a letter under the name of John Dickson to McCormick that explained how correspondents were coming under heavy Nazi suspicion. There was no indication in the letter on why Schultz decided to use Dickson at this particular time. The very fact that Schultz did not sign this letter under her real name suggests a new level of press scrutiny in Germany. She only used the name John Dickson to disassociate herself from critical articles in order to protect her identity in Berlin. Clearly, the information provided in this letter worried Schultz enough to risk using her other name in order to hide her authorship.

In the letter, Schultz relayed how correspondents were viewed with more suspicion in Germany which put not only them, but also their friends and other acquaintances in jeopardy. She mentioned how some friends in November told her that McCormick's "Berlin correspondent was under military suspicion." 307 Most likely, Schultz was relaying information about herself in order to communicate how her position was being compromised. She stated that the Berlin

\footnotetext{
${ }^{305}$ Schultz message to Mr. Maloney and Mr. Scharschug November 29, 1939, First Division Museum, Chicago Tribune Archive, I-62 Foreign Correspondents 1914-1955, Box 8, Folder 10.

${ }^{306}$ Schultz message to Mr. Maloney and Mr. Scharschug November 29, 1939.

307 John Dickson to Colonel McCormick February 10, 1940, First Division Museum, Chicago Tribune Archive, I-62 Foreign Correspondents 1914-1955, Box 8, Folder 10.
} 
correspondents' friends and casual acquaintances were being cross-examined by the German government. She contributed her trouble to her reporting news that was considered as restricted German military information. Unfortunately, she does not discuss the article that caused the problem with the German military. By the end of the letter, Schultz questioned if she should still attempt to report from Germany. She described that "[correspondents] run up against things that [were] so incredible, it seems useless to write about them, because the casual reader far away [would] think they [were] inspired by prejudice or hate and simply won't believe them."”308 However, this self-doubt did not stop herself from still reporting. She ends her letter with the statement "I don't think that I am allowing the black side of things to affect my determinations to be as factual as humanly possible." ${ }^{, 309}$ Schultz understood what type of risk she was taking by remaining in Germany. More importantly, this was a shared risk by any correspondent that dared to be critical.

To Sigrid Schultz's credit, many of her articles kept the same critical tone against the Nazis and were well informed about the current situation in Germany and the rest of Europe. ${ }^{310}$ An illustrative case in point is her article on May 17, 1940 that discussed how "idle" German women were seen as traitors. ${ }^{311}$ From 1939 to 1941, the German Labor Front attempted to increase the women labor force in the arms industry to improve the labor shortages brought about by the draft. ${ }^{312}$ The way Schultz's worded this article showed that the unemployed German

\footnotetext{
${ }^{308}$ John Dickson to Colonel McCormick February 10, 1940.

${ }^{309}$ John Dickson to Colonel McCormick February 10, 1940.

${ }^{310}$ For other examples of her harsh and informed articles see Sigrid Schultz, "Historical Past Will Be Signed Soon, Nazis Say," Chicago Tribune, PHN, March 17, 1940, 1; Sigrid Schultz, "Red Envoy Files Home As Berlin Spurs Axis Deal," Chicago Tribune, PHN, March 21, 1940, 1; Sigrid Schultz, "Germans Speed Secret Supplies to Swedish Port," Chicago Tribune, PHN, April 19, 1940, 1.

${ }^{311}$ Sigrid Schultz, "Idle Women are Traitors; That's [sic] View in Germany," Chicago Tribune, PHN, May 17, 1940, 3 .

${ }^{312}$ Richard Evans, The Third Reich at War 1939-1945 (New York: Penguin Books, 2008), 358-361.
} 
women may have been highly criticized. Her title literally stated, "Idle Women are Traitors." 313 Schultz also used several quotes in local German magazine that described how "no women has the right to object for the sake of her own wellbeing while soldiers are dying for her."314

Magazine and other local sources were strictly under the control of the Nazis party, which meant Schultz quoted the German government's position. Clearly, Schultz wanted to show that the German government was attempting to pressure women into their war plans.

One should note that Schultz's description of German labor was not entirely accurate. The Germans were starting to use foreign labors in large numbers from countries such as Poland and Italy in May of 1940 to fill the void left by the men. ${ }^{315}$ Schultz may not have recognized this based on her position in Berlin and had no additional evidence contrary to the magazines and the German women's situation. This does not mean that Schultz's critical nature in this article should be ignored. It also showed she still had the capacity of producing critical and inform above articles about Germany’s situation.

Another example of Schultz's famous critical writing was her article published on May 22, 1940 that predicted a German attack on England. The attack was not the important part of this article, but rather Schultz's explanation of why Germany was most likely preparing for one. Schultz wrote that "German astrologists have predicted that the planet Mercury, which they take to represent England will go thru [sic] terrific crises starting Thursday."316 She continued on to describe how "the star gazers have forecast the end of the war on June 4" and Hitler's interest in the study of the stars for the last several years. ${ }^{317}$ Schultz painted a picture of a military leader dependent on the stars and constellations for his war plans. The Chicago Tribune editors seemed

\footnotetext{
313 Sigrid Schultz, "Idle Women are Traitors; That's View in Germany."

${ }^{314}$ Schultz, "Idle Women are Traitors; That's View in Germany."

${ }^{315}$ Evans, The Third Reich at War 1939-1945, 348-349.

${ }^{316}$ Sigrid Schultz, "Predict Attack on England by End of the Week," Chicago Tribune, PHN, May 22, $1940,1$.

317 Schultz, "Predict Attack on England by End of the Week."
} 
to support Schultz's conclusions, because this article appeared on the front page of the newspaper. The nature of these articles suggest that Schultz still had some way to communicate her uncensored articles, but in her letter she showed how reporting was becoming impossible.

Ultimately, Schultz's undoing in Germany cannot be fully attributed to the Nazis and German press rules. The Nazis' strict control over information and press's rights were definitely a factor, however, an unforeseen problem was the deciding factor. Historian Nancy Caldwell Sorel argues that Schultz traveled to Spain in the first place, because she thought the Gestapo were preparing to arrest her in Germany. Sorel based her argument on an interview with Schultz decades later, but she failed to explain why Schultz wanted to return months later and the story in the Tribune about her short vacation. ${ }^{318}$ Schultz decided to go back to the United State by March of 1941, but the reason for her leaving Germany and Europe remains unclear.

One factor may have been her shrapnel wound from the year before that never fully healed. She received the wound in 1940, while doing a radio broadcast with CBS Broadcaster, William Shirer, in Berlin. A bomb landed on the CBS's studio, which led to Schultz being hit by flying shrapnel. Schultz was able to finish the radio broadcast with the wound, but it was never aired or recorded. The bomb also blew out their radio transmitter, which was their only way to broadcast it. $^{319}$

It was not uncommon for foreign correspondent to do radio broadcasts from Europe. In fact, the CBS was starting to set up the first European radio network in the late 1930s in order to report breaking news from such places as battles. Edward R. Murrow was one of the leading figure behind CBS's European network. He helped to establish the concept of breaking news and

\footnotetext{
${ }^{318}$ Nancy Caldwell Sorel, The Women Who Wrote the War (New York: Arcade Publishing, 1999), 110-111, 409. For the article about Schultz's vacation and stay in the US see Sigrid Schultz, "Crossing Europe to Peace! A view by Miss Schultz," Chicago Tribune, PHN, March 2, 1941, C7.

${ }^{319}$ Sorel, The Women Who Wrote the War, 110-111.
} 
radio's importance in foreign news reporting. ${ }^{320}$ As seen with Schultz's experience, this type of journalism had its own challenges for the correspondents in terms of equipment and safety. It would be interesting to try to gauge the impact of the radio on foreign news reporting, but this falls outside the scope of my study.

Another factor may have been the typhus she contradicted after she left Germany and travel to Spain. For a couple of weeks, she was required to be under hospital care and on bed rest in order to become healthily enough for the boat trip back to the US. Most of her recovery was to take place in United States, which meant Schultz had to leave Germany and Europe altogether. ${ }^{321}$ By the beginning of July in 1941, Sigrid Schultz was attempting to return to Germany; however, Colonel McCormick would not allow her to return due to the rising tensions and fear for Schultz's safety. ${ }^{322}$ In the end, Schultz agreed with McCormick's assessment of the situation in Germany. She even admitted that the "[she] never was confident that the Gestapo would let me leave if tensions increased much more." 323

In her letter to Pat Maloney on August 4, 1941, Schultz made a case for her to be sent to Portugal or Switzerland to keep reporting on the war news. ${ }^{324}$ She also refused to accept any speaking engagements with Jewish organization in order to keep up appearances with the Nazis if she ever returned to Germany. ${ }^{325}$ She did, however, not receive such a reporting position and

\footnotetext{
${ }^{320}$ Christopher B. Daly, Covering America: A Narrative History of a Nation's Journalism (Amherst \& Boston: University of Massachusetts Press, 2012), 232-235.

${ }^{321}$ She sent a couple of letters from her Westport home in Connecticut about recovering from her illness. See Sigrid Schultz to Mr. Scharschug on July 25, 1941, Wisconsin Historical Center (WHC), Sigrid Schultz's Papers, Box 4, Folder 4; Sigrid Schultz to Mr. Maloney on April 15, 1941, WHC, Sigrid Schultz's Papers, Box 4, Folder 4; and Sigrid Schultz to Mr. Deininger on March 31, 1941, WHC, Sigrid Schultz's Papers, Box 4, Folder 4.

${ }^{322}$ Sigrid Schultz to Mr. Maloney July 27, 1941, WHC, Sigrid Schultz's Papers, Box 4, Folder 4, and J.L. Maloney to Sigrid Schultz August 2, 1941, WHC, Sigrid Schultz's Papers, Box 4, Folder 4.

${ }^{323}$ Sigrid Schultz to Mr. Maloney on August 4, 1941.

${ }^{324}$ Sigrid Schultz to Mr. Maloney on August 4, 1941.

${ }^{325}$ Pmaloney [Pat Maloney] and Mr. Gerson on February 27, 1941, WHC, Sigrid Schultz's Papers, Box 4, Folder 4.
} 
would only returned to Europe in $1945 .{ }^{326}$ Schultz's leaving and being denied back to Europe cannot be explained by focusing on the Nazis' actions, Colonel McCormick's opinion, or even the fact that she was a women. It was a combination of all three factors and how Schultz's reacted to them that left the readers of the Chicago Tribune without a well-informed reporter in Berlin after 1941.

The Chicago Tribune did not have many other correspondents remaining in Germany after Sigrid Schultz had to leave in early 1941. Alex Small, the Chicago Tribune correspondent who covered the German invasion of Poland, would report from Germany after she left. ${ }^{327}$ There were no other reporters that remained in Germany long enough to write any substantial number of articles. After Germany declared war on the United States, Alex Small would become a Nazi "prisoner"-possibly an internee- along with other reporters. He was eventually released back to the US in May of 1942 with the other internees from Germany. ${ }^{328}$ Overall, the reporting from Berlin turned into individual Chicago Tribune reporters attempting to gather what limited news was available after $1941 .{ }^{329}$ Their counterparts in the New York Times News Bureau, Otto

\footnotetext{
${ }^{326}$ For examples of her articles in 1945 from Germany see Sigrid Schultz, "Dr. Kiep Hanged by Nazis in Fear of Peace Move," Chicago Tribune, PHN, April 15, 1945, 19; Sigrid Schultz, "Makes Germans View Horror of Death Factory," Chicago Tribune, PHN, April 18, 1945, 7; Sigrid Schultz, "A Woman Risks Life to all of German Terror," Chicago Tribune, PHN, April 23, 1945, 2.

${ }^{327}$ For examples of Small's reporting from Berlin see, Alex Small, "German who Stole 6 Sausages During Blackout Must Die," New York Times, PHN, February 23, c1; Alex Small, "Fashions Go Ersatz This Year at the Nazis' Big Fair at Leipzig," New York Times, PHN, March 1, 1941, 1; Alex Small, "U.S. Reporter Seized by Nazis on Spy Charge: Linked to 'Enemy Power’ by Berlin,” New York Times, PHN, March 16, 1941, C7.

${ }^{328}$ Alex Small, "Tribune Writer Tells of Life as Nazi 'Prisoner,' Chicago Tribune, PHN, May 18, 1942, 7. Most likely, Small was part of the diplomat exchanges that occurred between the United States and Germany after war was declared. For more information, see Landon Alfriend Dunn and Timothy J Ryan, Axis Diplomats in American Custody: The Housing of Enemy Representatives and Their Exchange for American Counterparts, 1941-1945 (Jefferson, North Carolina: McFarland \& Company, Inc., Publishers, 2016).

${ }^{329}$ Many of the articles that the Chicago Tribune published about Germany after 1941 came from its surrounding countries, such as Switzerland, or local German News Service. For examples, see "Hitler Fires Army Chief," Chicago Tribune, PHN, December 22, 1941; "Hitler Promises Victories in '42 But Not Peace," Chicago Tribune, PHN, January 31, 1942, 7; "19 U.S. Writers Held in Germany Start Own Paper," Chicago Tribune, PHN, March 26, $1942,3$.
} 
Tolischus, Frederick Birchall, and Guido Enderis, did not fare much better as Germany and the rest of Europe descended into war.

The New York Times News Bureaus across Europe started to prepare for war several months before the German invasion of Poland in 1939. It should not come as a surprise that the New York Times would develop such a plan, because the newspaper was under attack by the Nazis since 1933. However, plans could only predict so many of the possible reporting issues. In May of 1939, this plan was developed by Frederick Birchall, who clearly thought war was a strong possibility at any time. He was the New York Times Chief European Correspondent and had his share of run ins with the Nazis over his critical reporting. ${ }^{330}$ Birchall's plan for the news bureaus across Europe was based on his experiences from the previous war. Essentially, the individual correspondents would receive direction from the New York's office, because news bureaus would be dissolved or operate with skeleton staffs. Birchall surmised that the "Dailygraph System," which gave the telegraphed directions to the news bureaus, would be no longer operational. ${ }^{331} \mathrm{He}$ also argued that the Times would have to pay other local new agencies, such as the ones in London, to receive the basic news about current events. The news bureaus' chiefs were also required to draft war plans unique to their needs. ${ }^{332}$

The Berlin Bureau chief, Guido Enderis, did not think a war plan was necessary, because he thought Germany would not go to war this year (1939) and that any air attacks would not be able to reach Berlin. Therefore, Enderis decided to keep the bureau in its present condition,

\footnotetext{
${ }^{330}$ See Chapter Two page 93-94 for an example of Birchall having trouble with the German government.

${ }^{331}$ Memorandum on the Possibilities and Probable Actions of the European Service in the Event of War by Frederick Birchall May 30, 1939, New York Public Library, New York Times: Arthur Hays Sulzberger Papers, Box 249, Folder 2. Leff does not explicitly examine this document for her argument. She examined how Enderis refused to set up a plan, because he did not think war was possible. Enderis's choice should be criticized, because many people still held this opinion. It also would not affect how the new bureau functioned since the news was still being reported. See Leff, Buried in the Times, 61.

${ }^{332}$ Memorandum on the Possibilities and Probable Actions of the European Service in the Event of War by Frederick Birchall May 30, 1939.
} 
which Birchall thought was too optimistic. Consequently, Birchall developed his own plan, which was to establish a house on the outskirts of Berlin to keep the bureau's papers safe from any attack. He also gave instructions that in the case of war that Enderis would remain in Berlin in order to handle official communications, while Otto Tolischus was to take trips to the front and Peter Knauth would take care of "minor legwork." 333 In theory, this plan would have worked perfectly with the current dynamics of the bureau. Enderis was not writing many of the articles in order to help manage the relationship between the German government and New York Times. Tolischus and Birchall were writing the majority of the articles from Germany. ${ }^{334}$ However, Birchall and the other correspondents would learn quickly that no one could fully plan for war. The New York Times Berlin Bureau lost two of its foreign correspondents in Germany, Frederick Birchall and Otto Tolischus, within months of Wehrmacht invasion of Poland in September of 1939. The war in West was considered to be a "sitting war" due to war planning and weather, however, the countries were still considered at war and citizens of respecting countries would be enemy aliens. ${ }^{335}$ This meant that Frederick Birchall would not be freely able to travel in and out of Germany, because of his British citizenship, which he had not renounced. ${ }^{336}$ Therefore, Birchall became a potential enemy alien in Germany with Great Britain's declaration of war in 1939. He would be transferred to Canada for the rest of the war. ${ }^{337}$

Otto Tolischus's expulsion followed Birchall's shortly afterwards in early 1940. The reason why he was expelled was not as clear as in Birchall's case. Leff attributes Tolischus's

\footnotetext{
${ }^{333}$ Memorandum on the Possibilities and Probable Actions of the European Service in the Event of War by Frederick Birchall May 30, 1939.

${ }^{334}$ For more information about Enderis's role after 1933 see Chapter Two page 52 to 53.

335 Overy, Origins of Second World War, 83.

${ }^{336}$ Leff, Buried in the Times, 62.

${ }^{337}$ For examples of his articles from Canada see Frederick T. Birchall, "Getting at the Facts Despite the Censor," New York Times, PHN, October 15, 1939; and Frederick T. Birchall, "Canadians Elated by Progress of War at Home and in Europe," New York Times, PHN, December 20, 1939, 8.
} 
expulsion to his long history of critical articles about the Nazis' treatment of Jews. ${ }^{338}$ This is most likely true, however, the official reason for his expulsion remains unclear. Leff describes that in March of 1940, Tolischus was notified that his reporting permit would not be renewed. The German government did say that he could return after six weeks if he left Germany immediately, but nothing came of this deal. ${ }^{339}$ It is also difficult to confirm when Tolischus was fully expelled, because he remained in Europe in early 1940 following the invading Germans in Denmark and Norway. This would have required him to have some form of governmental approval to remain on the front and safe. ${ }^{340}$ Most correspondents considered this a privilege, because one would need German military approval. ${ }^{341}$ Clearly, Tolischus or the New York Times had some pull with the German military when the war began in September of 1939, because otherwise Tolischus would not be able to follow the army.

Most likely, the Nazis wanted to expel any remaining critical journalists in a quiet manner in order to protect the flow of information before the real fighting started with France and Great Britain. Tolischus's writing would fall under the category of critical journalism. Case in point, his front page article on September 8, 1939 described how the German press was molding the image of its invasion of Poland. ${ }^{342}$ Tolischus suggested that the press and the army command were ignoring French and British reports of artillery battles. He argued that "the press, by virtue of its own glowing accounts of German victories and on the basis of testimony by the

\footnotetext{
${ }^{338}$ Leff, Buried in the Times, 61.

${ }^{339}$ Leff, Buried in the Times, 61

${ }^{340}$ Schultz discussed her lack of German army approval in order to report on the front. See Sigrid Schultz to Mr. George J. Scharschug October 25, 1939, First Division Museum, Chicago Tribune Archive, I-62 Foreign Correspondents 1914-1955, Box 8, Folder 10.

${ }^{341}$ Schultz's letter to Mr. Scharschug October 25, 1939 talked about how she was not allowed on the war front, which hurt her ability to report news. See Sigrid Schultz to Mr. George J. Scharschug October 25, 1939, First Division Museum, Chicago Tribune Archive, I-62 Foreign Correspondents 1914-1955, Box 8, Folder 10. Historian Ernest K. Bramsted described how some correspondents were able to follow the Foreign Press Chief, Karl Böemer, at the Polish campaign. See Ernest K. Bramsted, Goebbels and National Socialist Propaganda 1925-1945 (United States of America: Michigan State University Press, 1965), 115.

342 Otto D. Tolischus, "Nazis Press Poles," New York Times, PHN, September 8, 1939, 1.
} 
allied Italian press, whose correspondents are the only foreign writers permitted to see the front line action, says Poland is in chaos and predicts her collapse within a few days." ${ }^{, 43}$ Further on in his article, Tolischus wrote, "despite the speed of the German advance and the claims of the press, German military quarters admit that the bulk of the Polish Army, while retreating, is still unbroken."344 The way Tolischus phrased his information about official and press accounts placed them under some serious doubt. The German government would not want this type of critical journalist remaining in Germany, where they could cause trouble by voicing negative opinions about its domestic actions to foreign countries.

Nevertheless, the Germans would not want to expel publicly an American journalist like Otto Tolischus without a reason. This would create an international issue with the United States, which the Nazis were not keen on due to war. It makes sense that the German government would simply lie to Tolischus about the possibility of him coming back to Germany after six weeks. ${ }^{345}$ This would push Tolischus out of Germany without much of a fuss and would allow him not return to Germany. Leff asserts that he followed the advancing German army into Denmark in 1940 and then was transferred to Japan in order to cover the growing tension in the Pacific. She also states that, "after Pearl Harbor, he was arrested and spent much of the war in Japanese captivity."346

There was no clear reason why he decided to move to those specific countries. Most likely, it was one of the last havens for correspondents to produce news without governmental interference. An article by Associated Press in March 1940 described how an air mail service was needed in Finland and Netherlands for American correspondents to get around the British

\footnotetext{
343 Tolischus, "Nazis Press Poles."

344 Tolischus, "Nazis Press Poles."

${ }^{345}$ Leff, Buried in the Times, 61.

${ }^{346}$ Leff, Buried in the Times, 61-62.
} 
and French censorship. ${ }^{347}$ As already discussed, Schultz used Copenhagen, Denmark to telephone her articles in the 1940s. Overall, Tolischus's experience in Germany was, yet another example of the German government silencing a reporter for the country's safety. This was not a rare occurrence in Germany as seen with Tolischus's and Schutlz's experiences.

This left the Berlin Bureau with Guido Enderis, Peter Knauth, and C. Brooks Peters to report the news. ${ }^{348}$ This staff would not give the New York Times much leeway in terms of reporting. Enderis wrote about 46 articles from 1939 to 1941, which averages to about 15 articles a year. ${ }^{349}$ Again, there was no clear explanation for why Enderis basically stopped writing. Most likely, it still relates back to his role of keeping the peace between the New York Times and the German government. This job probably became more difficult for Enderis, which was evident by Tolischus and Birchall not being allowed back into Germany. This left the New York Times with Knauth and Peters who were both novice reporters. ${ }^{350}$

From 1939 to 1941, Knauth only had 52 front page articles with the Times, while Peters had 55. Most of Knauth's and Peters' work can be compared to that of the Associated Press, because their articles' main intention seemed to be focused on providing basic information about Germany. For example, Knauth wrote an article on May 27, 1940 about the fighting near Dover, which only described the military situation. ${ }^{351}$ This fighting was part of a larger battle of Dunkirk, which was happening in France. The German army surrounded over 200,000 British

\footnotetext{
${ }^{347}$ Associated Press, "Dutch to Send Americans Air Mail Around Censors," New York Times, March 22. 1940, 8.

${ }^{348}$ Percy Knauth became a correspondent for the New York Times's office in Berlin on March 1939. Prior, he worked for the Chicago Tribune's office in Berlin during the 1930s. He was an American-born journalists, but was educated in Germany. He reported from Berlin until April 1941, which afterwards he became a war correspondent for the Time magazine. See Saxon Wolfgang, "Percy Knauth, 80, an Author And Foreign Correspondent," New York Times, PHN, January 21, 1995, 12. C. Brooks Peters became a journalist for the New York Times in 1937. After the United States entered the war, he decided to leave the New York Times in order to join the Marines and fought in the Pacific campaign. See "C. Brooks Peters, 84, Times Correspondent," New York Times, PHN, March 2, 1997, 36.

${ }^{349}$ This number was taken from the ProQuest Historical Newspaper database by inputting Guido Enderis as the author and Germany as the subject.

${ }^{350}$ Laurel Leff, Buried in the Times: The Holocaust and America's Most Important Newspaper (Cambridge: Cambridge University Press, 2005), 62-63.

${ }^{351}$ Percival Knauth, "Drive Near Dover," New York Times, PHN, May 27, 1940, 1.
} 
and French soldiers in Northern France and continued to pick them off by air plane attacks. Some of them were only saved by a quick evacuation. ${ }^{352}$ Knauth's focus was to explain the possible war plans for each side. Throughout this article, he does not draw any possible conclusions about the war or how either side was waging it. ${ }^{353}$

Another one of his articles on September 2, 1940 reported based on official reports how Germany remained unharmed after the British air attack. ${ }^{354}$ It does not matter if the attack reached Berlin or even happened, but the fact Knauth mainly used the official report by the Nazis was important in the article. The Nazis could have easily been lying in the reports in order to keep the home front calm and peaceful. The foreign correspondents' sources dictated what story news could be written. Knauth's article simply provided the official findings and nothing else.

C. Brooks Peters's articles were not a large improvement on Knauth's reporting. Many of his articles also used local German sources; however, Peters was more careful with them. For instance, Peters also wrote an article on September 12, 1940 about the British bombings in Berlin. He used the German press to show the German reaction to the bombing. One of his example headlines was "London Carries on Its Crazy Game to the End--Reichstag and American Embassy Bombed--Again Five Victims in Berlin Quarters." ${ }^{\text {,35 }}$ Peters explained how the press wanted to foster American anger by emphasizing that the bombs hit the United States Embassy. Peters's evidence from the German press would not shed light on everything occurring in Germany, but it provided some idea how the German government wanted to portray the events. He even ended his article with a quote, "The German press promises that 'the British will now

\footnotetext{
${ }^{352}$ Evans, The Third Reich at War 1939-1945, 127-130.

353 Percival Knauth, "Drive Near Dover," New York Times, PHN, May 27, 1940, 1.

354 Percival Knauth, "Berlin Unscathed in Raid, Nazis Say," PHN, September 2, 1940, 1.

355 C. Brooks Peters, "Berlin Threatens New Fury in Raids," New York Times, PHN, September 12, $1940,1$.
} 
feel the sword with all its sharpness." ${ }^{356}$ At the very least, Peters showed that the general sentiment in Germany towards Great Britain and how recent events were molded for the German public. It remains unclear whether or not these reporters continued to work after the US entered the war or what happened to them. ${ }^{357}$ His article cannot be compared to Schultz or Tolischus writing, because each journalists were at different points of their careers. More importantly, Knauth and Peters were facing an impossible situation under the wartime press rules. The official sources may have been their only option.

The lack of critical articles by Knauth and Peters was not completely their fault. Most likely, their comparative inexperience did not provide them with enough knowledge to work around the Nazis press system in order to gain a fuller picture. This may also have been to their advantage, because the most experienced journalists like Sigrid Schultz were slowly being expelled or forced out of Germany. The Germans would want inexperienced reporters, because it was easier to influence their writing. At the very least, the American public was provided with some information from Berlin. In the end, the youth of the remaining correspondents and Enderis's relationship would not keep the New York Times Berlin News Bureau open after Germany declared war on the United States at the end of 1941. Like the British and French correspondents, they were now considered enemy aliens for Germany and had to close their news bureau's doors. This left individual correspondents on their own in Germany as freelance journalists with the choice to leave or stay at their own risk. ${ }^{358}$

The foreign correspondents in Germany were not the only ones heavily affected by the start of the war. Correspondents all across Europe were subjected to new rules or at the very least

\footnotetext{
${ }^{356}$ Peters, "Berlin Threatens New Fury in Raids."

${ }^{357}$ Leff's map of New York Times correspondents throughout the war does not have these two correspondents assigned to another bureau after 1941 see Leff, Buried by the Times, xiii-xv.

${ }^{358}$ For a list of correspondents remaining in Germany after 1941 see Leff, Buried by The Times, xiv-xv.
} 
thrown into new roles by their newspapers once the war began. Essentially, Europe experienced a reshuffling of its communication network based on the tide of war. Some country like Sweden and Finland remained relatively censor-free and welcoming of correspondents for a short time, while others quickly tightened their control over information. ${ }^{359}$ It was up to the correspondents to understand how their communication networks changed based on their location. More importantly, they needed to decide if they should leave their host country due to the pressures of war. This can only be traced by examining how correspondents moved around Europe and attempted to send reports back to the United States. The correspondents' movements dictated what events were described in their respective newspapers, and, ultimately, influenced what was written for the general American public.

Unfortunately, there is not enough information about the correspondents' situation in France or Great Britain to come to any definitive conclusion. Many correspondents were stationed in both of the countries until Germany declared war on the United States and even in some cases well beyond 1941. In fact, many of these correspondents fled to France and England after German invasion of Poland in order to remain safe while reporting the news. ${ }^{360}$ There was a steady stream of articles being sent by the correspondents that suggests a basic communication structure remained intact. This does not mean the correspondents were not under some stress.

The few documents available suggest that an incident occurred with the New York Times in Paris after it fell to Germany. The New York Times had to close quickly their World Wide

\footnotetext{
${ }^{359}$ For examples of a journalists publishing in Sweden and Finland see Alex Small, "Retreat of Nazi Army in Poland Told by Writer," Chicago Tribune, PHN, October 20, 1939, 7; Alex Small, "Poland's Train at Standstill in Wake of Bombing," Chicago Tribune, PHN, October 11, 1939, 4; Donald Day, "Reds Call Finns to Discuss Deal on Nickel Mines," Chicago Tribune, PHN, January 28, 1941, 2; Donald Day, "Finns 'Unmask' Bolshevism as 'Great Swindle," Chicago Tribune, PHN, August 25, 1941, 7.

${ }^{360}$ For the list of New York Times's correspondents in London see Leff, Buried in the Times, xiv-xv. For some examples of Chicago Tribune correspondents' articles in England see Larry Rue, Front Page- No Title, Chicago Tribune, PHN, July 9, 1941, 1; Captain M.M. Corpening, "Life in London! How It Clicks," Chicago Tribune, PHN, October 19, 1940, 1; Joseph Cerutti, "Britain Orders 120,000 Children to Leave London," Chicago Tribune, PHN, June $10,1940,8$.
} 
photo offices in France on October 14, 1940 in order to protect its business interests and products. The letter does not clearly explain why the New York Times correspondents and other employees needed to close its office's doors. The author, C.M.C, seemed more worried about the Germans forcing him to reopen their doors despite the cost to the Times. ${ }^{361}$ A month later, a telegram arrived in Washington D.C. from an unknown author that discussed how the Germans took the Times's whole collection of photographs without any reason. ${ }^{362}$ These two documents cannot allow a definitive conclusion about the press's situation in France; however, they do suggest that more research needs to be done. More importantly, it also suggests what type of pressure and arbitrariness correspondents had to face in German occupied territories.

The foreign correspondents that found themselves in the middle of a German invasion faced challenging communication issues. Some of the Chicago Tribune correspondents in Eastern Europe had to move in order to send reports, because of their lack of access to communication outlets due to military advances. Alex Small's experience in Poland during the German invasion in September of 1939 is an illustrative case. He was assigned to Poland in early 1939, because Donald Day who was assigned to the region could not enter the country. ${ }^{363}$ This led to Small being one of the last foreign correspondents to leave Poland after the German invasion. ${ }^{364}$ He had to flee with the other foreign refugees in Poland and could not communicate with the Chicago Tribune for some of the time until he left Poland He was only able to publish

\footnotetext{
${ }^{361}$ C.M.C to Mr. Sulzberger October 14, 1940, New York Public Library, New York Times: General Company Records, Box 276, Folder 5.

${ }^{362}$ Telegram to Washington, November 30, New York Public Library, New York Times: General Company Records, Box 276, Folder 5. This telegram did not have a year written on it. Most likely, it was sent after France fall to Germany in June of 1940. The Germans would not have a capability to take materials in France.

${ }^{363}$ The reason for Day's expulsion from Poland is not entirely clear. He claims it was his critical reporting of the Polish government in his book; however, this is his opinion. Donald Day, Onward Christian Soldiers: 1920-1942: Propaganda, Censorship and One Man's struggle to Herald the Truth (Torrance, Calif: Noontide Press, 1982), 3. Alex Small's first article from Poland was in May of 1939 see Alex Small, "Nazi Slain; Poles Fear Coup," Chicago Tribune, PHN, May 22, 1939, 1.

${ }^{364}$ Small to Col. McCormick September 28, 1939, First Division Museum, Chicago Tribune Archives, I-62 Foreign Correspondents 1914-1955, Box 9, Folder 5.
} 
three stories in September from Poland before the German army cut off the communication lines out of Poland. Shortly after his last story on September 11, 1939, the Chicago Tribune lost contact with Small. ${ }^{365}$. Therefore, most of his articles could not be published until well after the fact, namely in October 1939 when he arrived in Amsterdam. ${ }^{366}$ This led to his stories becoming more of a human-interest story, because of the delay in time from his situation with the war.

This created an unfortunate situation where most of Small's eyewitness accounts did not appeared on the Chicago Tribune front page and were published weeks after the event in a series of articles in early October. ${ }^{367}$ Small stated that this city was still allowing censor-free communication, which was needed for his articles. Based on them, it cannot be certain whether Small wrote his articles in Poland during the invasion or after he arrived in Amsterdam. The only evidence that he may have written them during his travels was the statement in an article about his luggage consisting of half a typewriter. The other part was with a friend with whom he traveled through Poland. ${ }^{368}$

Nevertheless, Small's articles are an example of what happens to a correspondent if their host country crumbles underneath their feet. He had to make several choices about his reporting that were directly connected to his safety. On September 11, 1939, Small published an article from Poland in which he stated that foreign correspondents were not allowed at the front, but he

\footnotetext{
${ }^{365}$ Alex Small, "German Bomber Raids Villa of U.S. Ambassador," Chicago Tribune, PHN, September 4, 1939, 8; Alex Small, "Nazi Air Reaiders Rain Bombs on 3/4 of Polish Area," Chicago Tribune, PHN, September 5, 1939, 3; and Alex Small, "German Army's 4 Wave Attack Withers Poles," Chicago Tribune, PHN, September 11, 1939, 7. On September 23, 1939, the Chicago Tribune started to inquire about where Small may be located. See Chicago Tribune telegram September 23, 1939, First Division Museum, Chicago Tribune Archives, I-62 Foreign Correspondents 1914-1955, Box 9, Folder 5. Small did not communicate until September 28, 1939, which was when he left Poland. See Small to Col. McCormick September 28, 1939, First Division Museum, Chicago Tribune Archives, I-62 Foreign Correspondents 1914-1955, Box 9, Folder 5.

${ }^{366}$ Alex Small published a series of articles in the Chicago Tribune from September $5^{\text {th }}$ to October $21^{\text {st }}, 1939$. An article by Small does not appear on all of the dates, however, the entire series was published between those dates.

${ }^{367}$ For examples see, Alex Small, "Tribune Writer Tells of Seeing Poles' Breakup," Chicago Tribune, PHN, October 5, 1939, 1; and Alex Small, "War's Bad Times to End Quickly Berlin Believes," Chicago Tribune, PHN, October 6, 1939, 1.

${ }^{368}$ Alex Small, "Tribune Writer Tells of Seeing Poles’ Breakup.”
} 
still thought about going towards the story on the front and not fleeing to safety with the French and English. ${ }^{369}$ In another article on October 12, he described how on his journey out of Poland he was almost arrested and killed as a spy, because he appeared to be German to a Polish officer. ${ }^{370}$ In article on October 13, 1939, Small made a clear point of avoiding the Soviet line by stating "on no condition would we fall into the hands of the Bolsheviks without a struggle."371 The choices made by Small were heavily influenced by how he perceived his current situation in Poland. He was unable to receive any directions from editors or Colonel McCormick on how to proceed, which meant Small was effectively on his own in a middle of an invasion. Therefore, he had full control over what he reported back as the last foreign correspondent to leave Poland.

After 1940, reporters' actions had little effect on what they could report on from Poland. The Chicago Tribune and New York Times information on Poland dwindled down to almost nothing by 1940, which was when it became most important to the American public. The foreign correspondents had to leave for their safety, which made Poland almost a complete black zone for journalism during the war. Alex Small was the only correspondent from the Tribune who would go back into Poland for a twenty-four-hour tour by the Nazis on March $12,1941 .{ }^{372} \mathrm{He}$ described how the tour showcased the German propaganda intent and official story, which was the only direct information coming out of Poland. This meant Small had no choice, but to report that story and acknowledge the influence of the state. Unfortunately, German-occupied Poland was not the only place where journalism was guided by the government.

\footnotetext{
369 Alex Small, “Germany Army's 4 Wave Attack Withers Poles: Tanks, Flame Throwers Used in Assaults," Chicago Tribune, PHN, September 11, 1939

${ }^{370}$ Alex Small, "Writer Seized as Spy on Trek across Poland: Fears Raised After Bomb hit Ukrainian Towns," Chicago Tribune, PHN, October 12, 1939, 5.

${ }^{371}$ Alex Small, "Tells Confusion of Poles Caused by Red Invasion: Many Fleeing from Nazis Make an About Face," Chicago Tribune, PHN, October 13, 1939, 6.

${ }^{372}$ Alex Small, "Poland Today! Its People Find it Strange Land," Chicago Tribune, PHN, March 12, $1941,1$.
} 
The correspondents in Moscow and surrounding Eastern Europe countries constantly had to move around based on the conditions of war. The Chicago Tribune correspondent Donald Day was forced out of his news headquarters in Latvia by the Soviet Union in $1940 .{ }^{373}$ Day was stationed in Latvia because he was not allowed to report from the Soviet Union. It never approved his visa and the reason for the denial remains unclear. He claimed the Soviets did not like his critical reporting on communism and his failure to submit to their censorship; however, this was only his opinion. ${ }^{374}$ The important aspect to note is that Day thought he had to leave Latvia for his safety after the Soviet Union increased its pressure on the country for him to leave. Like many other reporters, he decided to flee to Finland because it was quickly emerging as a safe haven for correspondents from 1939 to $1941 .^{375}$ This effectively left the Chicago Tribune without any reporters in Eastern Europe for most of the war.

The New York Times's experience with the Soviet Union was not much different, however, the issue stemmed from the correspondents' inability to work under Soviet rules. G.E.R. Gedye was the New York Times correspondent assigned to Moscow in 1939 after he was expelled by the Germans from first Vienna and then Prague in 1938. Leff argues that he was sent to Moscow, because Sulzberger wanted to cure him of his "left political leanings." The question of political bias could not be solved; however, Leff asserts Gedyre had great difficulties reporting from Russia due to his lack of understanding the Russian culture and language. This led to the Times's publisher, Arthur Sulzberger, debating about the value of having a Moscow News Bureau. ${ }^{376}$

\footnotetext{
${ }^{373}$ Day, Onward Christian Soldiers, vi-vii.

${ }^{374}$ Day, Onward Christian Soldiers, iv-v, 107-109.

${ }^{375}$ For examples of his articles from Finland see Donald Day, "Reds Call Finns to Discuss Deal on Nickel Mines," Chicago Tribune, PHN, January 28, 1941, 2; Donald Day, "Finns 'Unmask' Bolshevism as 'Great Swindle,"” Chicago Tribune, PHN, August 25, 1941, 7; Donald Day, "War Refugees’ Plight Grave Russia Admits,” Chicago Tribune, PHN, December 23, 1941.

${ }^{376}$ Leff, Buried in the Times, 124-125.
} 
By early 1940, New York Times editor Edwin James sent a letter to Arthur Sulzberger about Gedye's inability to report the news from Moscow. He argued that Gedye let the story die instead of pushing them through the Soviet censorship. ${ }^{377}$ Gedye asserted that it was impossible to report as Soviet censorship did not allow the reporters to send the full story. ${ }^{378}$ The New York Times asked their freelancer Walter Duranty to write a report about the situation in Moscow. He concluded that the situation is not impossible; however, Gedye did not attitude to work with the Soviet Union. It is also important to note that historians characterized Duranty's reporting as highly influenced by the Soviet Union and often adapted its point of view. This influence could have affected his assessment of the situation and Gedye. ${ }^{379}$ Leff describes how Gedye would leave the New York Times for unclear reasons by the end 1940. This caused the Times to close its Moscow News Bureau until they found a replacement journalists in $1941 .^{380}$

The correspondents across Europe did not face the same kinds of pressures from the war; however, the solution remained consistent among the correspondents. When the war began, all of the correspondents needed to find reliable communication networks in order to keep reporting from Europe. This required the correspondents to leave their host countries, which in most cases required travel to Sweden or Denmark. The correspondents had to find neutral or relatively stable countries in order to report the news back to the US, because these countries had communication outlets. This would severely limit what news correspondents could report on, which shaped what was provided to the general American public.

\footnotetext{
${ }^{377}$ E.L. James to Mr. Sulzberger May 28, 1940, New York Public Library, New York Times: Arthur Hays Sulzberger Papers, Box 208, Folder 15; and Leff also reached a similar conclusion based on other documents see Leff, Buried in the Times, 124-125.

${ }^{378}$ G.E.R. Geyde to Mr. Sulzberger Sept 24, 1940, New York Public Library, New York Times: Arthur Hays Sulzberger Papers, Box 208, Folder 15.

${ }^{379}$ Walter Duranty's report to Mr. Edwin James April 5, 1940, New York Public Library, New York Times: Arthur Hays Sulzberger Papers, Box 208, Folder 15. For more information about historians' evaluation of Duranty's political bias, see S.J. Taylor, Stalin's Apologist: Walter Duranty The New York Times's Man in Moscow (New York: Oxford University Press, 1990).

${ }^{380}$ Leff, Buried in the Times, 124-125.
} 
The choices made by correspondents from 1939 to 1941 appear to be small when considering how a newspaper was published. However, correspondents provide the foundation for the newspaper to inform the American public about the war. This means that the correspondents' reporting played a crucial role in how the general American public viewed the events developing in Europe. A perfect correspondent did not exist in this time period. Much of their reporting capabilities were dependent purely on luck and on their individual situation. More importantly, the way reporters reacted to their situation dictated what type of reports were sent back to the United States.

Some correspondents decided to work within their host country's rules in order to remain welcome. Others decided to challenge the rules as long as possible, before the country found a way to expel them. The correspondents were not wrong choosing either one of these paths; however, it is important to realize that the correspondents decided their path based on their perception of the current situation. Once the war began, newspaper owners and their editors could only influence their correspondents to a certain point, because communication was limited. The deciding factor was how the correspondent reacted to their host countries' press rules. This choice and perception would cause a ripple effect onto the front page of the newspapers and into the eyes of their readers.

On December 7, 1941, the foreign correspondents' situation completely changed along with the rest of the United States. On this day Japan executed a decisive attack on the United States' naval base at Pearl Harbor. Germany declared war on the United States on December 11 to help support its Japanese allies. This effectively changed the correspondents into enemies of the state and removed any protection left for the correspondent, because they are no longer 
connected or from a neutral country. The remaining correspondents had the choice of remaining at their post with the constant threat of danger or leaving Europe for safer grounds. 


\section{CHAPTER V}

\section{CONCLUSION: THE UNSEEN GATEKEEPER OF INFORMATION ${ }^{381}$}

I feel very odd to be entering the era of Government-controlled journalism.

It is my first experience. I was a Managing Editor in the last war, and

we had a wide field for the exercise of our own judgement. ${ }^{382}$

-Arthur Krock (New York Times News Bureau Chief) on December 19,1941

December 11, 1941 is often referred to as the day when World War II turned into a true world conflict, because Germany declared war on the United States. This was the start of a watershed moment that would change the entire world, and it also ushered in a new era of journalism. In a general sense, the world became aware of the media's role in influencing public opinion. The countries could not afford their respective publics' opinion to turn against the war, because it would be impossible to wage a successful war without a supportive home front. It makes logical sense that any government would take steps to influence the media for their own goals. Nevertheless, this era did not develop over night or became common governmental policy after December of 1941; it was preceded by a decade of changes to press rules.

The changes to journalism can only be seen by studying the foreign correspondents' agency in publishing the news during the 1930s, because the new press rules affected how they could write about Europe. This case study of the New York Times and Chicago Tribune foreign correspondents in Europe illustrate how a highly complicated system of foreign news reporting emerged due to the steady stream of new governmental rules on reporting in the 1930s. It should be noted that the correspondents across Europe did not face the same press challenges. The type of press rules was highly dependent on their individual locations. The correspondents' ability to

\footnotetext{
${ }^{381}$ The idea of a journalists as a gatekeeper of information was taken from Hellmueller's article. See Lea Hellmueller, "Gatekeeping Beyond Geographical Borders: Developing an Analytical Model of Transnational," The International Communication Gazette 79, no. 1 (2017): 3-8.

${ }^{382}$ AK [Arthur Krocks] to Arthur Hays Sulzberger December 19, 1941, New York Public Library, New York Times: Arthur Hays Sulzberger Papers, Box 125, Folder 5.
} 
face each of them partially shaped what information was available about Europe to the American public; thus, placing them in the gatekeeper role of information. The rest of the responsibility laid with the editors who placed their individual articles into the newspaper.

Between 1930 to 1934, correspondents stationed in Germany were one of the few who had to contend with governmental press rules. The Chicago Tribune Berlin correspondent Sigrid Schultz's experience is the best example of how a government attempted to influence foreign correspondents' writing, because her reporting very early on brought her into conflict with the German government. The fact that her reporting was an issue for the German government showed how governments were paying more attention to the media at the start of the 1930s. An illustrative case was how the Weimar government attempted to stop Adolf Hitler from interviewing with the press to keep him from becoming more popular with the masses. Schultz's connections in Germany allowed her to get an interview with Hitler in 1931. She was also able to critically write about Hitler's intention for Germany in order to provide one of the earliest warnings about him. Unfortunately, this article and many others like it never reached the front page of the newspaper. ${ }^{383}$ The German government attempts to regulate the press, especially in regards to Hitler, may have been well-intentioned, but set a bad precedent for later regimes.

The correspondents in Germany only had a brief transition period, while the Nazis consolidated their power from 1933 to 1934 . The correspondents' situation changed by the end of 1934 to where their reporting directly influenced their safety. They were faced with a choice of working with the German press rules or facing governmental repercussions. There was a strong possibility of the reporters being expelled or, even worse, arrested by the Gestapo. A journalist should not be completely defined by their decision to work with the Germans on their

${ }^{383}$ For a detailed discussion on Schultz's interview with Hitler see Chapter One page 28 to 31. 
press rules, because both of the choices had their merits for foreign reporting. It is the agency of the reporter to choose which path would work best for their situation and reporting.

Laurel Leff argues that the New York Times had a fragile relationship with the Germans, because its owner and publisher was Jewish. Essentially, it already had a strike against it due to the German anti-Jewish policies. ${ }^{384}$ Leff underestimates the New York Times Berlin Bureau chief, Guido Enderis, role in protecting this relationship. After 1934, Enderis started to develop a working relationship with the Germans. The details of this relationship remain unclear; however, the value of it can be seen in how Enderis negotiated for New York Times other correspondents to stay in Germany. ${ }^{385}$ Leff describes several instances in which Enderis protected Frederick Birchall and Otto Tolischus, who were some of the most critical foreign journalists of the Third Reich. ${ }^{386}$ Their articles in the 1930s would not have been published had Enderis not assumed this role of negotiator with the Germans. Most likely, the New York Times would have been closed down if this fragile relationship with the Germans had not been fostered.

This relationship began to collapse after the war began in September of 1939. The New York Times had two of its stronger correspondent, Frederick Birchall and Otto Tolischus, expelled from Germany. This left them with Enderis, who barely reported any news, and two young, naive reporters. After 1940, the Times articles from Berlin decreased dramatically and turned into mostly simple news reports about the war and Europe; however, the bureau remained open until Germany declared war on the United States. ${ }^{387}$ Enderis's role should not be underestimated, because his relationship on some level helped the Times to remain open in an impossible situation.

\footnotetext{
${ }^{384}$ Leff, Buried in the New York Times, 55-56.

${ }^{385}$ For a discussion on Enderis's relationship see Chapter One pages 50 to 51.

${ }^{386}$ Leff, Buried by the Times, 58-59.

${ }^{387}$ For a detailed discussion on the New York Times correspondents in Berlin after 1939 see Chapter Three pages 108 to 115 .
} 
The other choice for journalists was to work around the German press rules; however, this could be dangerous for the correspondent and their acquaintances. Sigrid Schultz became famous among journalists for her ability to work with the German system and as one of the most knowledgeable correspondents in the country, which showed through in her critical articles about the Third Reich. She had the abilities to work around the German press rules, because of her European upbringing and journalistic drive. ${ }^{388}$ Case in point, she had multiple acquaintances with higher Nazis officials, such as Herman Göring. She was also good friends with the American Ambassador William Dodd. ${ }^{389}$ This allowed her to gain access to confidential information that would not have been presented at the daily German press conferences.

Throughout the 1930s, Schultz had to change her reporting methods in order to keep writing, because German press rules tightened. Essentially, the German government wanted to have control over the flow of information through any means necessary. Schultz avoid some of its control by leaving Germany to send articles from Prague back to the United States; however, after 1939 many of her communication lines became useless due to the war. ${ }^{390}$ Many of the European correspondents first fled to Denmark and Sweden, because communication outlets were still uncensored and efficient in sending messages. ${ }^{391}$ This changed after the German invasion of Denmark in early 1940, which made it a German-occupied territory. Sweden remain neutral; however, it had a working relationship with the Germans. ${ }^{392}$ Ultimately, this forced correspondents to fled towards countries such as Great Britain that were not under German control. She also used a different byline to distance herself from her critical articles using the

\footnotetext{
${ }^{388}$ For more information about Schultz's upbringing, see Chapter One page 21-22.

${ }^{389}$ See Chapter Two pages 65.

${ }^{390}$ For a discussion on how Schultz developed her communication line in Prague see Chapter One page 50-51 and Chapter Two page 100-101.

${ }^{391}$ See Chapter Three page 115-120.

${ }^{392}$ Richard Evans, The Third Reich at War 1939-1945 (New York: Penguin Books, 2008),118-122.
} 
male alias of John Dickson. This is also a commentary on gender in reporting. It made more sense for an editor to place her most critical articles under a male name. ${ }^{393}$ These were only two of the many changes she made to her reporting; however, they could only keep Schultz safe in Germany for so long.

Schultz was not able to remain in Germany much after the start of 1941 and it was not from a lack of drive or knowledge to remain under the radar from the Nazis. The reason for her leaving has not been fully explained, but in the months beforehand she had received multiple threats from the Germans. As Schultz chose to write around the German press rules, she was in constant conflict with the German government and risking her safety. Throughout the 1930s, Schultz was able to work in the German press system, which allowed her to produce a constant stream of critical article.

The correspondents described above were only two examples discussed throughout the study. All of the correspondents who were highlighted had unique approaches to reporting the news that shaped what type of news their editors placed in the newspaper. The foreign correspondents were forced throughout the 1930s to make choices based on their individual situations that influenced what news was reported back to the American public. It is important to understand how the correspondents decided to report and their respective problems, because their varying experiences illustrate the development of a new governmental journalism system and their agency within publishing the news.

Ultimately, the importance of journalists' agency never faded after the end of the war. It is even more crucial today when the new administration describes the media as "enemy of the

\footnotetext{
${ }^{393}$ See Chapter Two pages 89 to 92.
} 
American people. ${ }^{394}$ The journalists are the ones who attempt to interpret events and to provide information for the public. In the 1930s, the foreign correspondents in Europe faced varying governmental attempts to influence their reporting. The way they decided to work with their respective governments dictated their role in publishing the news and his continues to be the case for journalists then and now.

${ }^{394}$ BBC, "Enemies of the People': Trump Remark Echoes History's Worst Tyrants," BBC News, accessed March 1, 2017, http://www.bbc.com/news/world-us-canada-39015559. 


\section{BIBLIOGRAPHY}

\section{Secondary Sources}

Alder, Selig. The Isolationists Impulse: Its Twentieth-Century Reaction. New York: The Free Press, 1957.

BBC. "Enemies of the People': Trump Remark Echoes History’s Worst Tyrants.” BBC News. Accessed March 1, 2017. http://www.bbc.com/news/world-us-canada-39015559.

Berger, Meyer. The Story of the New York Times 1851-1951. New York: Simon and Shuster, 1951.

Bramsted, Ernst K. Goebbels and National Socialist Propaganda 1925-1945. United States of America: Michigan State University Press, 1965.

Breitman Richard and Allan J. Lichtman. FDR and the Jews. Cambridge, Massachusetts and London, England: The Belknap Press of Harvard University Press, 2013.

Brennen, Bonnie. "Cultural Discourse of Journalists: The Material Conditions of Newsroom Labor." In Newsworkers: Towards a History of the Rank and File, edited by Hanno Hardt and Bonnie Brennen, 75-109. Minneapolis and London: University of Minnesota Press, 1995.

Buljung, Brianna. "From the Foxhole: American Newsmen and the Reporting of World War II," International Social Science Review 86, no. 1-1 (2011): 44-64.

Carlson, Peter. "Dorothy Thompson Underestimates Hitler.” American History 50, no. 4 (Oct 2015): 16-17.

Cole, Wayne. America First: The Battle Against Intervention 1940-1941. Madison: The University of Wisconsin Press, 1953.

Cole, Wayne. Roosevelt \& the Isolationists 1932-1945. Lincoln and London: University, 1988. 
Conradi, Peter. Hitler's Piano Player: The Rise and Fall of Ernst Hanfstaengl, Confidant of Hitler, Ally of FDR. New York: Carroll \& Graf Publishers New York, 2004.

Daly, Christopher B. Covering America: A Narrative History of a Nation's Journalism. Amherst \& Boston: University of Massachusetts Press, 2012.

Doenecke, Justus D. and John E. Wilz, From Isolation to War: 1931 to $1941,4^{\text {th }}$ ed. The American History Series. Malden, MA: John Wiley\& Sons, 2015.

Dunn, Landon Alfriend and Timothy J Ryan. Axis Diplomats in American Custody: The Housing of Enemy Representatives and Their Exchange for American Counterparts, 1941-1945. Jefferson, North Carolina: McFarland \& Company, Inc., Publishers, 2016.

Edwards, Jerome E. The Foreign Policy of Col. McCormick's Tribune 1929-1941. Reno, Nevada: University of Nevada Press, 1971.

Evans, Richard J. The Coming of the Third Reich. New York: The Penguin Press, 2004.

Evans, Richard J. The Third Reich in Power 1933-1939. New York: The Penguin Press, 2005.

Evans, Richard. The Third Reich at War 1939-1945.New York: The Penguin Books, 2008.

Fisher, Klaus. Nazi Germany: A New History. New York: Continuum, 1998.

Fiss, Karen. Grand Illusion: The Third Reich, the Paris Exposition, and the Cultural Seduction of France. Chicago \&London: The University of Chicago Press, 2009.

Foreign Correspondent. Directed by Alfred Hitchcock. Released August 16, 1940. Hulu, July 3, 2011. video streaming, 120 minutes.

Fulda, Bernhand. Press and Politics in the Weimar Republic. Oxford: Oxford University Press, 2009.

Hamilton, John Maxwell. Journalism's Roving Eye: A History of American Foreign Reporting. Baton Rouge: Louisiana State University Press, 2009. 
Hardt, Hanno. "Without the Rank and File: Journalism History, Media Workers, and Problems of Representation.” In Newsworkers: Towards a History of the Rank and File, edited by Hanno Hardt and Bonnie Brennen, 1-29. Minneapolis and London: University of Minnesota Press, 1995.

Heald, Morrell. Transatlantic Vistas: American Journalists in Europe, 1900-1940. Kent, Ohio: Kent State University Press, 1988.

Hellmueller, Lea and Claudia Mellado. "Professional Roles and News Construction: A Media Sociology Conceptualization of Journalists' role Conception and Performance.” Communication \& Society 28, no. 3 (2015): 1-11.

Hellmueller, Lea. "Gatekeeping Beyond Geographical Borders: Developing an Analytical Model of Transnational." The International Communication Gazette 79, no. 1 (2017): 3-25.

Johnstone, Andrew. Against Immediate Evil: American Internationalists and the Four Freedoms on the Eve of World War II. Ithaca and London: Cornell University Press, 2014.

Kaplan, Marion A. Between Dignity and Despair: Jewish Life in Nazi Germany. New York and Oxford: Oxford University Press, 1998.

Klatt, Wayne. Chicago Journalism: A History. Jefferson, North Carolina, and London: McFarland \& Company, Inc., Publishers, 2009.

Klein, Gary. “When the News Doesn't Fit: The New York Times and Hitler's First Two Months in Office, February/ March 1933.” J\&MC Quarterly 78, no. 1 (Spring 2001): 127-149.

Kreutzfeldt, Jacob. "Unidentified Sounds: Radio Reporting From Copenhagen 1931-1949." Journal of Radio \& Audio Media 22, no. 1 (2015): 3-19.

Kruglak, Theodore Edward. The Foreign Correspondents: A Study of the Men and Women Reporting for the American Information Media in Western Europe. Westport, 
Connecticut: Greenwood Press, Publishers, 1974.

Kurth, Peter. American Cassandra: the Life of Dorothy Thompson. Boston: Little, Brown, 1990.

Leff, Laurel. Buried by The Times: The Holocaust and America's Most Important Newspaper. New York: Cambridge University Press, 2005.

Lipstadt, Deborah E. Beyond Belief: The American Press and the Coming of the Holocaust 19331945. New York: The Free Press, 1986.

McKinney, Megan. The Magnificent Medills: America's Royal Family of Journalism During a Century of Turbulent Splendor. New York: Harper, 2011.

Nord, David Paul. Communities of Journalism: A History of American Newspapers and Their Readers. Urbana and Chicago: University of Illinois Press, 2001.

Overy, Richard. Origins of the Second World War. 3rd ed. Seminar Studies in History. Harlow, England and London: Pearson Longman, 2008.

Plamper, Jan. "Abolishing Ambiguity: Soviet Censorship Practices in the 1930s.” Russian Review 60, no. 4 (Oct 2001): 526-44.

Rossi, John. "Hitchcock’s Foreign Correspondent." Film \& History 12, no. 2 (May 1982): 25-35.

Scharnberg, Harriet. "Das A und P Der Propaganda: Associated Press und die nationalsozialistishch Bildpublizistik.” Studies in Contemporary History (2016). Accessed April 3, 2016. http://www.zeithistorische-forschungen.de/1-2016/id\%3D5324.

Seul, Stephanie. “Herr Hitler's Nazis Hear an Echo of World Opinion': British and American Press Responses to Nazi Anti-Semitism, September 1930- April 1933.” Politics, Religion \& Ideology 14, no. 3 (Sept 2013): 412-430.

Sington, Derrick and Arthur Weidenfeld. The Goebbels Experiment: A Study of the Nazi Propaganda Machine. New Haven and Yale University, 1943. 
Smelser, Ronald. "The Holocaust in the Popular Culture: Master-Narrative and CounterNarratives in the Gray Zone." In Gray Zones: Ambiguity and Compromise in the Holocaust and its Aftermath, edited by Jonathan Petropoulos and John K. Roth, 270-285. New York: Berghahn Books, 2005.

Smith, Richard Norton. The Colonel: The Life and Legend of Robert R. McCormick 1880-1955. Boston and New York: Houghton Mifflin Company, 1997.

Sorel, Nancy Caldwell. The Women Who Wrote the War. New York: Arcade Publishing, 1999. Taylor, S.J. Stalin's Apologist: Walter Duranty The New York Times's Man in Moscow. New York: Oxford University Press, 1990.

Teel, Leonard Ray. The Public Press, 1900-1945: The History of American Journalism. Westport, Conn.: Praeger Publishers, 2006.

Tworek, Heidi J.S. "Journalistic Statesmanship: Protecting the Press in Weimar Germany and Abroad." German History 32, no. 4 (2014): 559-578.

Tworek, Heidi. “The Creation of European News: News Agency Cooperation in Interwar Europe.” Journalism Studies 14, no. 5 (2013): 730-742.

Voss, Frederick S. Reporting the War: The Journalistic Coverage of World War II. Washington, D.C.: Smithsonian Institution Press for National Portrait Gallery, 1994.

Wachsmann, Nikolaus. Kl: A History of the Nazi Concentration Camps. New York: Farrarr, Straus and Giroux, 2015.

Wendt, Lloyd. Chicago Tribune: The Rise of a Great American Newspaper. Chicago: Rand McNally, 1979.

Williams, Kevin. "War Correspondents as Sources for History: Problems and possibilities in Journalism Historiography." Media History 18, no. 3-4 (2012): 341-360. 


\section{Dissertations}

Chapman, Cynthia C. "Psychobiographical Study of the life of Sigrid Schultz." PhD diss., Florida Institute of Technology, 1991.

Marwell, David George. "Unwonted Exile: A biography of Ernst "Putzi” Hanfstaengl." PhD diss., State University of New York, 1988.

\section{Published Sources}

Day, Donald. Onward Christian Soldiers: 1920-1942: Propaganda, Censorship and One Man's Struggle to Herald the Truth. Torrance, Calif: Noontide Press, 1982.

Dodd, William E. Jr and Martha Dodd, ed. Ambassador Dodd's Diary. New York: Harcourt, Brace and Company, 1941.

Schultz, Sigrid. Germany Will Try Again. New York: Reynal \& Hitchcock, 1944.

Shirer, William L. Berlin Diary: The Journal of a Foreign Correspondents 1934-1941. New York: Groseet \& Dunlap, 1940.

\section{Periodicals}

New York Times

Chicago Tribune

Archival Materials

Chicago Tribune Archive at the First Division Museum

Sigrid Schultz's Papers at Wisconsin Historical Society

New York Times Company Records at New York Public Library 